2. To: (Receiving organization) Packaging Engineering

5. Proj./Prog./Dept./Div.:

$03 \mathrm{E} 00$
3. From: (originating Organization) Packaging Engineering

6. Design Authority/ Design Agent/Cog. Engr.:

J. C. McCoy
8. Originator Remarks:

The attached SEP is being submitted for approval and release.

11. Receiver Remarks:
11A. Design Baseline Document?

[] Yes
[X] No
4. Related EDT No.:

622365

7. Purchase Order No.:

NA

9. Equip./Component No.: NA

10. System/Bldg./Facility: NA

12. Major Assm. Dwg. No.: NA

13. Permit/Permit Application No.: NA

14. Required Response Date: $\mathrm{NA}$

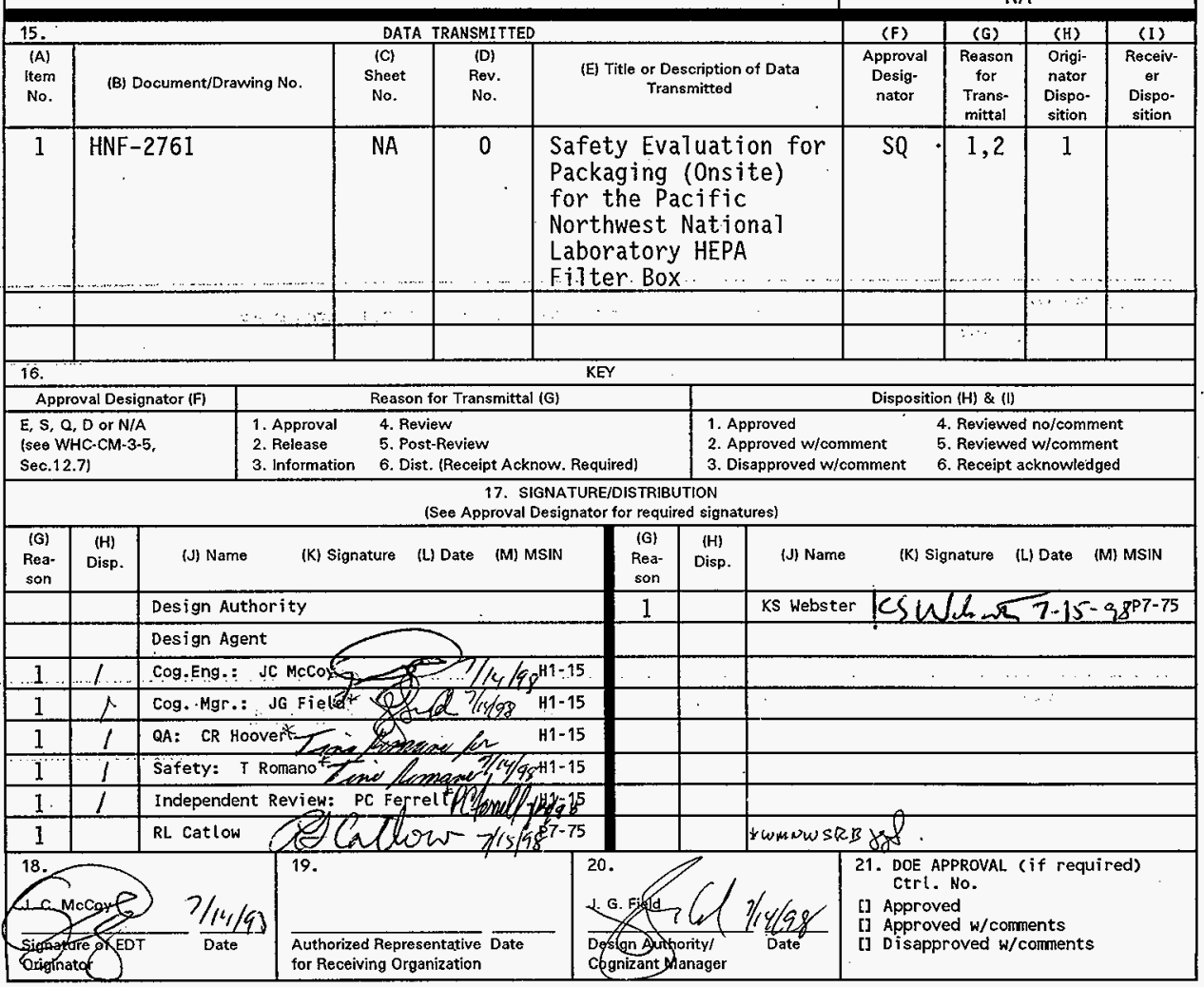




\title{
Safety Evaluation for Packaging (Onsite) for the Pacific Northwest National Laboratory HEPA Filter Box
}

\section{J. C. McCoy}

Waste Management Federal Services, Inc.,

Northwest Operations, Richland, WA 99352

for Fluor Daniel Hanford, Inc.

U.S. Department of Energy Contract DE-AC06-96RL13200

\author{
EDT/ECN: EDT $622375 \quad$ UC: 513 \\ Org Code: $03 \mathrm{E} 00$ \\ Charge code: P0 A48732, Task 3 \\ Project 772035, 40-014-001 \\ B\&R Code: \\ Tota1 Pages: 138
}

Key Words: Type B, transport, 300 Area, Central Waste Complex, 200 West Area

Abstract: This safety evaluation for packaging (SEP) evaluates and documents the safe onsite transport of eight high-efficiency particulate air (HEPA) filters in the Pacific Northwest National Laboratory HEPA Filter Box from the 300 Area of the Hanford Site to the Central Waste Complex and on to burial in the 200 West Area. Use of this SEP is authorized for 1 year from the date of release.

TRADEMARK DISCLAIMER. Reference herein to any specific comercial product, process, or service by trade name, trademark, manufacturer, or otherwise, does not necessarily. constitute or imply its endorsement, recommendation, or favoring by the United States Government or any agency thereof or its contractors or subcontractors.

Printed in the United States of America. To obtain copies of this document, contact: WHC/BCS Document Control Services, P.0. Box 1970, Mailstop H6-08, Richland WA 99352, Phone (509) 372-2420; Fax (509) 376-4989.
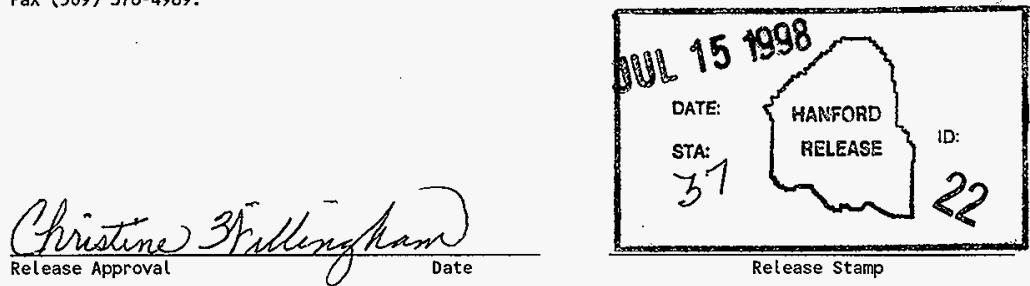

Approved for Public Release 
CONTENTS

PART A: DESCRIPTION AND OPERATIONS

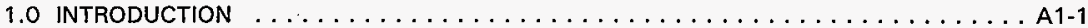

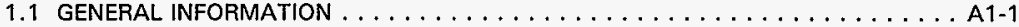

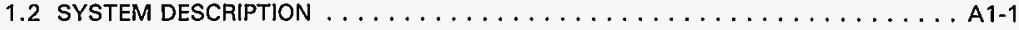

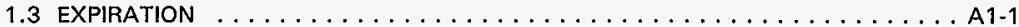

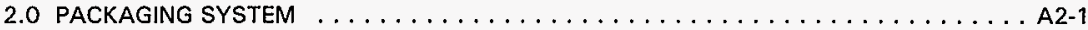

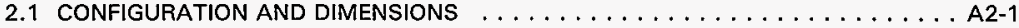

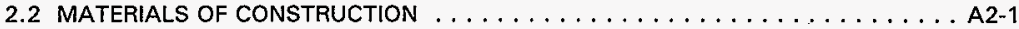

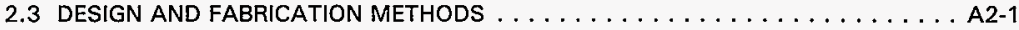

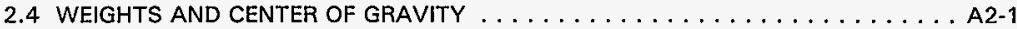

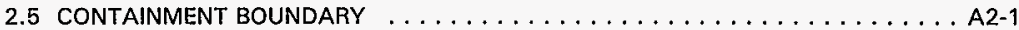

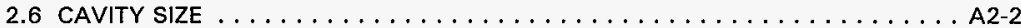

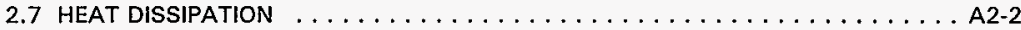

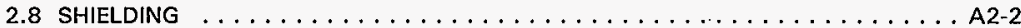

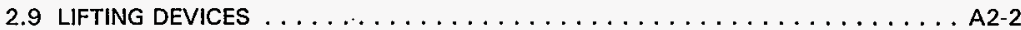

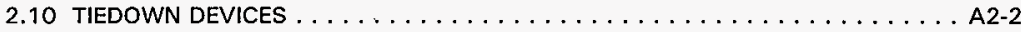

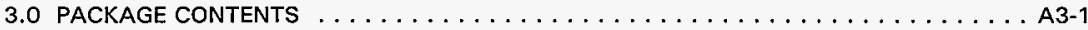

3.1 GENERAL DESCRIPTION $\ldots \ldots \ldots \ldots \ldots \ldots \ldots \ldots \ldots \ldots \ldots \ldots \ldots$. $\ldots \ldots$ A3-1

3.2 CONTENTS RESTRICTIONS $\ldots \ldots \ldots \ldots \ldots \ldots \ldots \ldots \ldots \ldots \ldots \ldots$ A3-1

4.0 TRANSPORTATION SYSTEM $\ldots \ldots \ldots \ldots \ldots \ldots \ldots \ldots \ldots \ldots \ldots \ldots \ldots$. . . . . . . . . . .

4.1 TRANSPORTER $\ldots \ldots \ldots \ldots \ldots \ldots \ldots \ldots \ldots \ldots \ldots \ldots \ldots \ldots$ A4-1

4.2 TIEDOWN SYSTEM AND CARGO CONFIGURATION $\ldots \ldots \ldots \ldots \ldots \ldots \ldots \ldots$. . . . .

4.3 SPECIAL TRANSFER REQUIREMENTS $\ldots \ldots \ldots \ldots \ldots \ldots \ldots \ldots \ldots \ldots$. . . . . . . $\ldots \ldots$

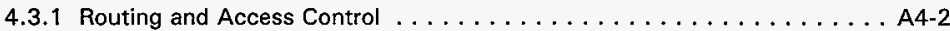

4.3.2 Radiological Limitations . . . . . . . . . . . . . . . . . A A4-2

4.3.3 Speed Limitations . . . . . . . . . . . . . . . . . . A4-3

4.3.4 Environmental Conditions . . . . . . . . . . . . . . A4-3

4.3.5 Frequency of Use and Mileage Limitations $\ldots \ldots \ldots \ldots \ldots \ldots \ldots$ A4-3

5.0 ACCEPTANCE OF PACKAGING FOR USE $\ldots \ldots \ldots \ldots \ldots \ldots \ldots \ldots \ldots \ldots \ldots \ldots$

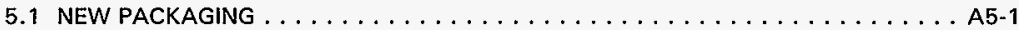

5.2 PACKAGING FOR REUSE $\ldots \ldots \ldots \ldots \ldots \ldots \ldots \ldots \ldots \ldots \ldots \ldots \ldots \ldots \ldots \ldots \ldots \ldots$

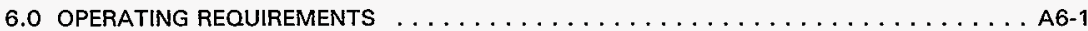

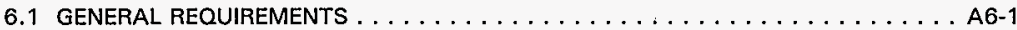

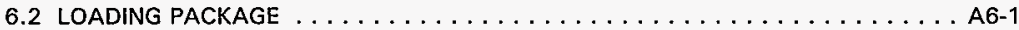

6.3 TRUCK LOADING AND TRANSPORTING $\ldots \ldots \ldots \ldots \ldots \ldots \ldots \ldots \ldots \ldots \ldots$ A6-1

6.4 UNLOADING PACKAGE $\ldots \ldots \ldots \ldots \ldots \ldots \ldots \ldots \ldots \ldots \ldots \ldots \ldots \ldots \ldots \ldots$

7.0 QUALITY ASSURANCE REQUIREMENTS . . . . . . . . . . . . . . . A7-1

7.1 GENERAL REQUIREMENTS . . . . . . . . . . . . . . . . . A7-1

7.2 SEP CONTROL SYSTEM $\ldots \ldots \ldots \ldots \ldots \ldots \ldots \ldots \ldots \ldots \ldots \ldots \ldots$ A7-1

8.0 MAINTENANCE $\ldots \ldots \ldots \ldots \ldots \ldots \ldots \ldots \ldots \ldots \ldots \ldots \ldots \ldots \ldots$

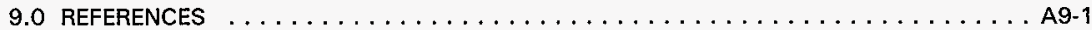


CONTENTS (cont.)

10.0 APPENDICES $\ldots \ldots \ldots \ldots \ldots \ldots \ldots \ldots \ldots \ldots \ldots \ldots \ldots \ldots$. . . . . . . . . . . . . . . .

10.1 PACIFIC NORTHWEST HEPA FILTER CHECKLISTS $\ldots \ldots \ldots \ldots \ldots \ldots \ldots$. . . A10-1

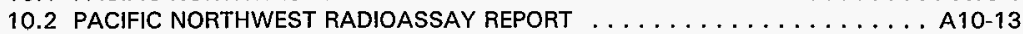

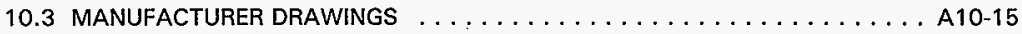

\section{PART B: PACKAGE EVALUATION}

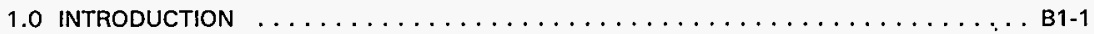

1.1 SAFETY EVALUATION METHODOLOGY $\ldots \ldots \ldots \ldots \ldots \ldots \ldots \ldots \ldots \ldots \ldots \ldots$

1.2 EVALUATION SUMMARY AND CONCLUSIONS $\ldots \ldots \ldots \ldots \ldots \ldots \ldots \ldots$ B1-1

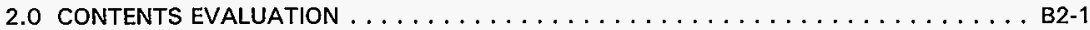

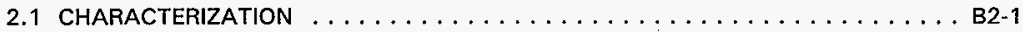

2.1.1 Radioactive Source Term . . . . . . . . . . . . . . . . B2-1

2.1.2 Chemical Source Term . . . . . . . . . . . . . . B2-1

2.2 RESTRICTIONS . . . . . . . . . . . . . . . . . . . . . B

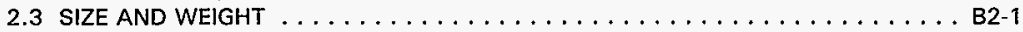

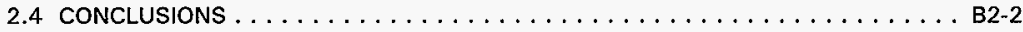

3.0 RADIOLOGICAL RISK EVALUATION $\ldots \ldots \ldots \ldots \ldots \ldots \ldots \ldots \ldots \ldots \ldots$

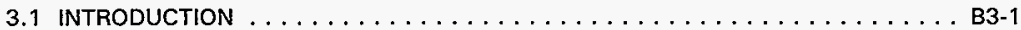

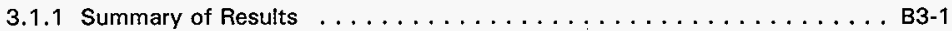

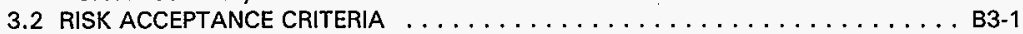

3.3 DOSE CONSEQUENCE ANALYSIS RESULTS $\ldots \ldots \ldots \ldots \ldots \ldots \ldots \ldots \ldots$. . . . . . .

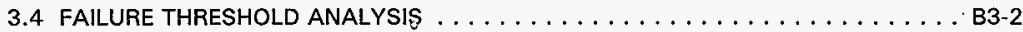

3.5 ACCIDENT FREQUENCY ASSESSMENT $\ldots \ldots \ldots \ldots \ldots \ldots \ldots \ldots \ldots \ldots \ldots \ldots$

3.6 EVALUATION AND CONCLUSION $\ldots \ldots \ldots \ldots \ldots \ldots \ldots \ldots \ldots \ldots \ldots \ldots$

3.7 REFERENCES $\ldots \ldots \ldots \ldots \ldots \ldots \ldots \ldots \ldots \ldots \ldots \ldots \ldots \ldots \ldots$

4.0 CONTAINMENT EVALUATION $\ldots \ldots \ldots \ldots \ldots \ldots \ldots \ldots \ldots \ldots \ldots \ldots \ldots \ldots$

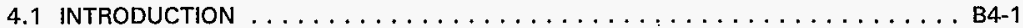

4.2 CONTAINMENT SOURCE SPECIFICATION $\ldots \ldots \ldots \ldots \ldots \ldots \ldots \ldots \ldots \ldots$. . . . $\ldots \ldots \ldots$

4.3 NORMAL TRANSFER CONDITIONS $\ldots \ldots \ldots \ldots \ldots \ldots \ldots \ldots \ldots \ldots \ldots$ B4-1

4.3.1 Conditions To Be Evaluated $\ldots \ldots \ldots \ldots \ldots \ldots \ldots \ldots \ldots \ldots \ldots \ldots$ B4-1

4.3.2 Containment Acceptance Criteria . . . . . . . . . . . . . . B4-1

4.3.3 Containment Calculations . . . . . . . . . . . . . . . B4-1

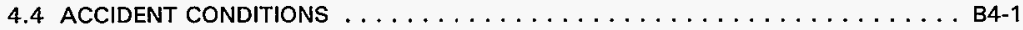

4.5 CONTAINMENT EVALUATION AND CONCLUSIONS $\ldots \ldots \ldots \ldots \ldots \ldots \ldots \ldots$. . . $\ldots \ldots$

4.6 DOSE CONSEQUENCE ANALYSIS (OF ACCIDENTS) $\ldots \ldots \ldots \ldots \ldots \ldots \ldots$ B4-2

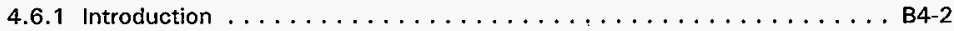

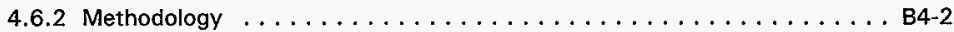

4.6 .3 Source Term $\ldots \ldots \ldots \ldots \ldots \ldots \ldots \ldots \ldots \ldots \ldots \ldots \ldots \ldots$

4.6.4 External Dose Due to Photon (Gamma) Exposure . . . . . . . . . . . . B4-3

4.6.5 External Dose Due to Beta Particle Emitters . . . . . . . . . . . . . B4-3

4.6.6 Inhalation and Ingestion Dose . . . . . . . . . . . . . . B4-3

4.6.7 Dose Due to Beta-Particle Emitter Skin Contamination . . . . . . . . . B B4-6

4.6 .8 Submersion Dose Due to Gaseous Vapor . . . . . . . . . . . . . B4-6

4.6 .9 Special Considerations . . . . . . . . . . . . . . . . B4-6 


\section{CONTENTS (cont.)}

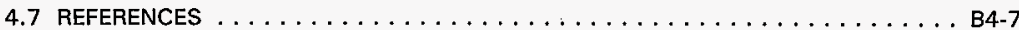

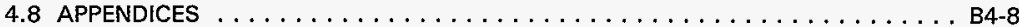

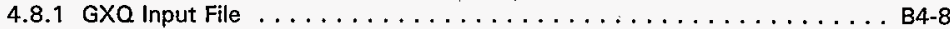

4.8 .2 GENII Input File $\ldots \ldots \ldots \ldots \ldots \ldots \ldots \ldots \ldots \ldots \ldots \ldots$ B4-10

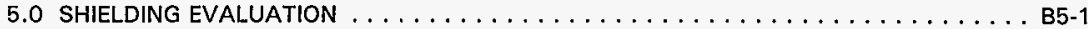

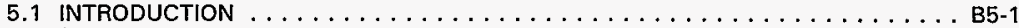

5.2 APPENDIX: SURVEY REPORT $\ldots \ldots \ldots \ldots \ldots \ldots \ldots \ldots \ldots \ldots \ldots \ldots$ B $\ldots \ldots \ldots$

6.0 CRITICALITY EVALUATION $\ldots \ldots \ldots \ldots \ldots \ldots \ldots \ldots \ldots \ldots \ldots \ldots \ldots \ldots \ldots \ldots$

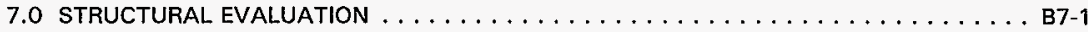

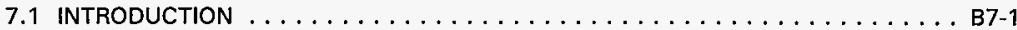

7.2 STRUCTURAL EVALUATION OF THE PACKAGE $\ldots \ldots \ldots \ldots \ldots \ldots \ldots \ldots \ldots$. . . $\ldots \ldots$

7.2.1 Structural Description of Package $\ldots \ldots \ldots \ldots \ldots \ldots \ldots \ldots \ldots \ldots$ B $\ldots \ldots$

7.2.2 Chemical and Galvanic Reactions . . . . . . . . . . . . . . B7-1

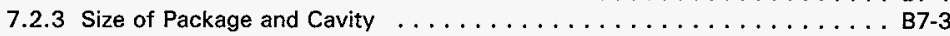

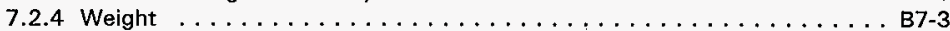

7.2.5 Tamper-Indicating Devices $\ldots \ldots \ldots \ldots \ldots \ldots \ldots \ldots \ldots \ldots \ldots$. . . . . . . . . . . . .

7.2.6 Positive Closure . . . . . . . . . . . . . . . . . . . . B7-3

7.2.7 Lifting and Tiedown Devices . . . . . . . . . . . . . . . . . B7-3

7.3 NORMAL TRANSFER CONDITIONS $\ldots \ldots \ldots \ldots \ldots \ldots \ldots \ldots \ldots \ldots \ldots$

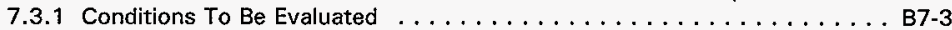

7.3.2 Acceptance Criteria . . . . . . . . . . . . . . . . . . . . B7-4

7.3.3 Hot and Cold Evaluation . . . . . . . . . . . . . . . . B7-4

7.3.4 Reduced and Increased External Pressure . . . . . . . . . . . B7-4

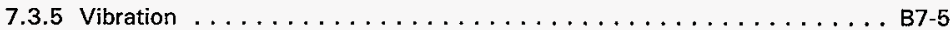

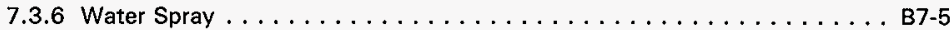

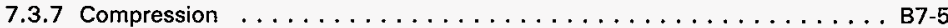

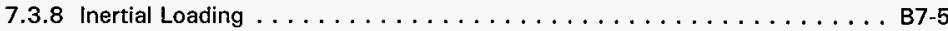

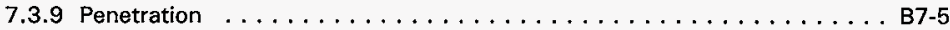

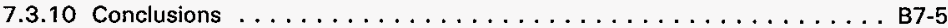

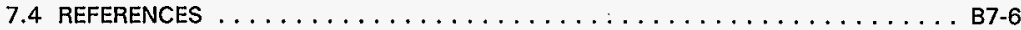

7.5 APPENDIX: STRUCTURAL ANALYSIS $\ldots \ldots \ldots \ldots \ldots \ldots \ldots \ldots \ldots$ B $\ldots \ldots$

8.0 THERMAL EVALUATION $\ldots \ldots \ldots \ldots \ldots \ldots \ldots \ldots \ldots \ldots \ldots \ldots \ldots \ldots \ldots \ldots \ldots$

8.1 INTRODUCTION $\ldots \ldots \ldots \ldots \ldots \ldots \ldots \ldots \ldots \ldots \ldots \ldots$ B8-1

8.2 THERMAL EVALUATION $\ldots \ldots \ldots \ldots \ldots \ldots \ldots \ldots \ldots \ldots \ldots \ldots \ldots$ B 1

8.2.1 Package Description $\ldots \ldots \ldots \ldots \ldots \ldots \ldots \ldots \ldots \ldots$ B8-1

8.3 NORMAL TRANSFER CONDITIONS THERMAL EVALUATION $\ldots \ldots \ldots \ldots \ldots \ldots$. . . . B8-1

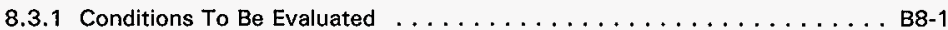

8.3.2 Acceptance Criteria . . . . . . . . . . . . . . . . . B8-1

8.3.3 Thermal Evaluation and Conclusions $\ldots \ldots \ldots \ldots \ldots \ldots \ldots$. . . . . . . .

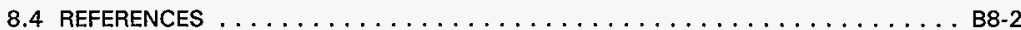

8.5 APPENDIX: THERMAL ANALYSIS $\ldots \ldots \ldots \ldots \ldots \ldots \ldots \ldots \ldots \ldots$ B8-3

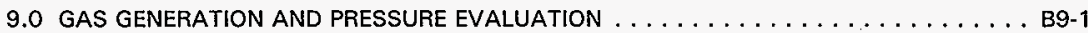

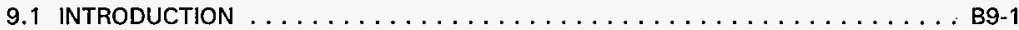

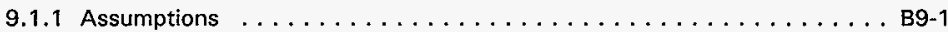

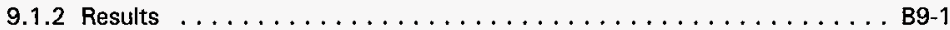


HNF-2761, Rev. 0

\section{CONTENTS (cont.)}

9.2 GAS GENERATION AND PACKAGE PRESSURE $\ldots \ldots \ldots \ldots \ldots \ldots \ldots \ldots$. . . .

9.2.1 Conditions To Be Evaluated . . . . . . . . . . . . . . . . B B9-1

9.2 .2 Acceptance Criteria . . . . . . . . . . . . . . . . . . B9-1

9.2.3 Engineering Analysis $\ldots \ldots \ldots \ldots \ldots \ldots \ldots \ldots \ldots$ Bg-1

10.0 TIEDOWN EVALUATION $\ldots \ldots \ldots \ldots \ldots \ldots \ldots \ldots \ldots \ldots \ldots \ldots \ldots \ldots \ldots$ B10-1

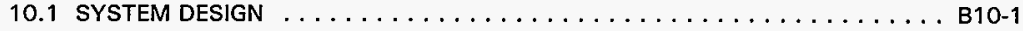

10.2 ATTACHMENTS AND RATINGS $\ldots \ldots \ldots \ldots \ldots \ldots \ldots \ldots \ldots \ldots$ B10-1

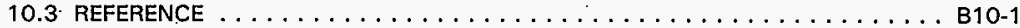

10.4 APPENDIX: TIEDOWN ANALYSIS $\ldots \ldots \ldots \ldots \ldots \ldots \ldots \ldots \ldots \ldots$ B10-2

\section{LIST OF FIGURES}

A4-1 Truck Loading Arrangement and Details $\ldots \ldots \ldots \ldots \ldots \ldots \ldots \ldots \ldots$. . . . . . . . .

B7-1 HEPA Filter Box. $\ldots \ldots \ldots \ldots \ldots \ldots \ldots \ldots \ldots \ldots \ldots \ldots \ldots \ldots \ldots \ldots$

\section{LIST OF TABLES}

A3-1 Source Term $\ldots \ldots \ldots \ldots \ldots \ldots \ldots \ldots \ldots \ldots \ldots \ldots \ldots \ldots \ldots$

A4-1 External Container Contamination Limits $\ldots \ldots \ldots \ldots \ldots \ldots \ldots \ldots \ldots \ldots$. . . . A4-3

B2-1 HEPA Filter Box Source Term $\ldots \ldots \ldots \ldots \ldots \ldots \ldots \ldots \ldots \ldots \ldots \ldots \ldots \ldots$

B3-1 Risk Acceptance Criteria Limits (Effective Dose Equivalent) . . . . . . . . . . . B3-2

B3-2 Summary of Dose Consequence Results $\ldots \ldots \ldots \ldots \ldots \ldots \ldots \ldots \ldots \ldots \ldots$ B3-2

B4-1 Summary of Doses for Maximum Public Receptor for an Accident (Nonthermal)

Event Involving the $\mathrm{Box} \ldots \ldots \ldots \ldots \ldots \ldots \ldots \ldots \ldots \ldots \ldots \ldots \ldots \ldots$

B4-2 Accident Release Quantities. . . . . . . . . . . . . . . . B4-4 


\section{LIST OF TERMS}

\begin{tabular}{|c|c|}
\hline ARF & airborne release fraction \\
\hline ASTM & American Society for Testing and Materials \\
\hline B\&PVC & Boiler and Pressure Vessel Code \\
\hline $\mathrm{Bq}$ & becquerel \\
\hline $\mathrm{Btu} / \mathrm{ft}^{2} / \mathrm{h}$ & British thermal units per square foot per hour \\
\hline $\begin{array}{l}\mathrm{Btu} / \mathrm{h}-\mathrm{ft}-{ }^{\circ} \mathrm{F} \\
\mathrm{cal} / \mathrm{cm}^{2} / \mathrm{h}\end{array}$ & $\begin{array}{l}\text { British thermal units per hour-foot degree Fahrenheit } \\
\text { calories per square centimeter per hour }\end{array}$ \\
\hline $\mathrm{Ci}$ & curie \\
\hline $\mathrm{cm}$ & centimeter \\
\hline $\mathrm{dpm} / \mathrm{cm}^{2}$ & disintegrations per minute per square centimeter \\
\hline EDE & effective-dose equivalent \\
\hline EPDM & ethylene-propylene diene monomer \\
\hline & inside diameter \\
\hline in. & inch \\
\hline $\mathrm{ft}$ & foot \\
\hline$f t-l b$ & foot-pound \\
\hline g & gram \\
\hline $\mathrm{g} / \mathrm{cm}^{3}$ & grams per cubic centimeter \\
\hline $\mathrm{g} / \mathrm{cm}^{2}$ & grams per square centimeter \\
\hline gal & gallon \\
\hline IAEA & International Atomic Energy Agency \\
\hline $\mathrm{J} / \mathrm{kg}-\mathrm{K}$ & joules per kilogram kelvin \\
\hline $\mathrm{kg}$ & kilogram \\
\hline $\mathrm{kg} / \mathrm{m}^{3}$ & kilograms per cubic meter \\
\hline $\mathrm{km}$ & kilometer \\
\hline $\mathrm{km} / \mathrm{h}$ & kilometers per hour \\
\hline $\mathrm{kPa}$ & kilopascal \\
\hline ksi & 1000-lb per square inch \\
\hline $\mathrm{lb}$ & pound \\
\hline $\mathrm{lb} / \mathrm{ft} \mathrm{t}^{3}$ & pounds per cubic foot \\
\hline LSA & low specific activity \\
\hline $\mathrm{m}$ & meter \\
\hline $\mathrm{MeV}$ & megaelectronvolt \\
\hline$\mu \mathrm{Ci} / \mathrm{cm}^{2}$ & microcuries per square centimeter \\
\hline $\mathrm{mi}$ & mile \\
\hline $\mathrm{MPa}$ & megapascal \\
\hline $\mathrm{mph}$ & miles per hour \\
\hline mrem $/ \mathrm{h}$ & millirem per hour \\
\hline $\mathrm{mSv} / \mathrm{h}$ & millisievert per hour \\
\hline NTC & normal transfer conditions \\
\hline Pacific Northwest & Pacific Northwest National Laboratory \\
\hline & pounds per square inch \\
\hline psia & pounds per square inch, absolute \\
\hline $\mathrm{OA}$ & quality assurance \\
\hline $\mathrm{rem} / \mathrm{h}$ & rem per hour \\
\hline SEP & safety evaluation for packaging \\
\hline$s / m^{3}$ & seconds per cubic meter \\
\hline Sv & sievert \\
\hline Sv/h & sievert per hour \\
\hline $\mathrm{TBq}$ & terabecquerel \\
\hline TCRP & total conditional release probability \\
\hline$W / m^{2}-K$ & watts per square meter kelvin \\
\hline
\end{tabular}


HNF-2761, Rev. 0

This page intentionally left blank. 
HNF-2761, Rev. 0

\section{SAFETY EVALUATION FOR PACKAGING (ONSITE) FOR THE PACIFIC NORTHWEST NATIONAL LABORATORY HEPA FILTER BOX}

\section{PART A: DESCRIPTION OF OPERATIONS}

\subsection{INTRODUCTION}

\subsection{GENERAL INFORMATION}

This safety evaluation for packaging (SEP) evaluates and documents the ability of the Pacific Northwest National Laboratory (Pacific Northwest) High-Efficiency Particulate Air (HEPA) Filter Box to meet the packaging requirements of HNF-PRO-154, Responsibilities and Procedures for all Hazardous Material; HNF-PRO-157, Radioactive Material/Waste Shipments; HNF-PRO-163, Documentation and Record Keeping; and HNF-PRO-166, Transportation Safety Training Requirements, for the onsite transfer of Type B quantities of radioactive material. Onsite transfer is the transport of hazardous materials on controlled routes confined to established limited areas and on portions of federally owned roadways to which public access is prohibited during transfer.

The Pacific Northwest HEPA Filter Box will be used for transport of eight HEPA filters from the 300 Area of the Hanford Site to the Central Waste Complex and on to burial in the 200 West Area. This SEP demonstrates, by analysis or by reference to existing safety analysis reports for packaging, that the Pacific Northwest HEPA Filter Box meets the onsite transportation safety requirements.

\subsection{SYSTEM DESCRIPTION}

The packaging consists of a carbon steel box with an inner carbon steel box for shielding of four of the filters. The inner box contains four filters while the other four are packed around it. The outer box was procured by Pacific Northwest on Purchase Requisition 208888-A85. The box drawings are shown in Part A, Section 10.3. The overall box with payload weighs approximately $4947 \mathrm{~kg}(10,907 \mathrm{lb})$ with external dimensions of $2.55 \mathrm{~m}$ long, $1.35 \mathrm{~m}$ wide, and $1.64 \mathrm{~m}$ high (100.5 in, 53.2 in, 64.5 in) overall.

Tiedown of the package for transport will be accomplished using a modified application of standard techniques as specified in Part A, Section 4.2.

\subsection{EXPIRATION}

Use of this SEP is authorized for the period of 1 year from the date of release. If it becomes desirable to maintain the packaging design for ongoing use, it will be necessary to prepare a safety analysis report for packaging. 
HNF-2761, Rev. 0

This page intentionally left blank:

A 1-2 


\subsection{PACKAGING SYSTEM}

\subsection{CONFIGURATION AND DIMENSIONS}

The Pacific Northwest HEPA Filter Box consists of an inner and outer box containing eight HEPA filters from Building 325 . The outer box has external dimensions of approximately $255 \mathrm{~cm}$ long (100.5 in.) by $135 \mathrm{~cm}$ (53.2 in.) wide by $164 \mathrm{~cm}$ (64.5 in.) high. The box interior dimensions are $245 \mathrm{~cm}$ (98.0 in.) long by $127 \mathrm{~cm}$ (50.0 in.) wide by $147 \mathrm{~cm}(58.0 \mathrm{in.}$ ) high. The box has four forklift pockets equally spaced on the bottom and three lid lifting attachments on the top. The box has a gasketed closure secured by bolts. The internal steel box provides shielding for four of the HEPA filters. The inner box dimensions are $179 \mathrm{~cm}$ (70.0 in.) long by $91.0 \mathrm{~cm}$ (36.0 in.) wide by $140 \mathrm{~cm}$ (55.0 in.) high. Four HEPA filters are contained in the inner box and four between the inner and outer box.

\subsection{MATERIALS OF CONSTRUCTION}

The inner and outer boxes are constructed with American Society for Testing and Materials (ASTM) A36 and ASTM-569 carbon steel. The gasket and closure bolts are detailed on the manufacturer drawings attached in Part A, Section 10.3.

\subsection{DESIGN AND FABRICATION METHODS}

The outer box was procured as a "Strong-Tight" box in accordance with the requirements of 49 CFR 173.24 and 49 CFR 173.410. The manufacturer drawings are attached in Part $A$, Section 10.3. The inner box was fabricated at Hanford, and no drawings exist.

\subsection{WEIGHTS AND CENTER OF GRAVITY}

The gross weight of the loaded Pacific Northwest HEPA Filter Box is reported by Pacific Northwest to be approximately $4,915 \mathrm{~kg}(10,835 \mathrm{lb})$. The calculated gross weight shown in Part B, Section 7.0 , is $4947 \mathrm{~kg}(10,907 \mathrm{lb})$.

The vertical center of mass is located $69.0 \mathrm{~cm}(27.1 \mathrm{in.})$ above the bottom of the package (the bottom of the channeis). If the inner box was centered within the outer, the horizontal position of the center of mass would coincide with the geometric center of the outer box; but if the inner box is as far from the center as possible, the package center of mass would be located $33.0 \mathrm{~cm}(13.0 \mathrm{in.}$ ) longitudinally and $16.0 \mathrm{~cm}(6.3 \mathrm{in.})$ laterally from the geometric center.

\subsection{CONTAINMENT BOUNDARY}

The containment boundary is the box wali, lid, and lid gasket. However, the radioactive materiais are entrained on the four HEPA filters, which are loaded in the inner box. The combination of the outer box walls, lid, and lid gasket and the inner box walis and lid will serve to confine the radioactive material inside the inner box during normal transfer conditions. Note that the four HEPA filters packaged between the inner and outer boxes did not show any evidence of radioactive material, but could not be released as nonradioactive. The filter checklist data is provided in Part A, Section 10.1. 


\subsection{CAVITY SIZE}

The inner dimensions of the outer box are $245 \mathrm{~cm}$ ( $98.0 \mathrm{in.}$ ) long by $127 \mathrm{~cm}$ (50.0 in.) wide by $147 \mathrm{~cm}(58.0 \mathrm{in}$.$) high. The inner dimensions of the inner box are 170 \mathrm{~cm}(67.0 \mathrm{in}$.) long by $83.8 \mathrm{~cm}$ (33.0 in.) wide by $130 \mathrm{~cm}(51.0 \mathrm{in.}$ ) high.

\subsection{HEAT DISSIPATION}

The decay heat of $0.17 \mathrm{~W}$ within the Pacific Northwest HEPA Filter Box is considered negligible.

\subsection{SHIELDING}

Shielding on the package consists of the inner box with walls. The walls are $3.8 \mathrm{~cm}(1.5 \mathrm{in}$. on the sides with a $5 \mathrm{~cm}(2-i n$.$) top and a 5.7 \mathrm{~cm}(2.25$-in.) bottom.

\subsection{LIFTING DEVICES}

The box has four forklift pockets on the bottom. The lid may be lifted using the three tiedown pockets on the lid. Because the box is already packaged for disposal, a lid lift is not considered likely.

\subsection{TIEDOWN DEVICES}

The box contains no integral tiedown devices and will be blocked, braced, and secured as described in Part A, Section 4.0. 


\subsection{PACKAGE CONTENTS}

\subsection{GENERAL DESCRIPTION}

The Pacific Northwest HEPA Filter Box contents consist of eight HEPA filters. The locations these filters were removed from are contained in the filter checklists attached in Part $A$, Section 10.1. Four filters are contained in an inner box and contain the entire detectable radioactive inventory. The other four filters are packed between the inner and outer boxes and do not contain detectable levels of radioactive materials. The filters contain no organic materials or materials that may produce substantial quantities of gas as a result of exposure to radiation.

The total radioactive inventory of the four contaminated filters is shown in Table A3-1. The data were obtained from a Pacific Northwest evaluation provided in Part A, Section 10.2. The box contains a nonfissile, Type $B$, non-highway route controlled quantity of material.

\subsection{CONTENTS RESTRICTIONS}

No further materials may be added to the box prior to shipment.

Table A3-1. Source Term.

\begin{tabular}{|c|c|c|c|c|}
\hline \multirow{2}{*}{ Isotope } & \multicolumn{2}{|c|}{ Activity } & \multirow{2}{*}{$\mathrm{A}_{2}(\mathrm{Ci})$} & \multirow{2}{*}{$\begin{array}{c}\text { Fraction of } \\
\mathrm{A}_{2}\end{array}$} \\
\hline & $\mathrm{TBq}$ & $\mathrm{Ci}$ & & \\
\hline${ }^{60} \mathrm{Co}$ & $\begin{array}{l}7.36 \\
E-03\end{array}$ & 1.99 E-01 & $\begin{array}{c}1.08 \\
E+01\end{array}$ & $1.84 \mathrm{E}-02$ \\
\hline${ }^{90} \mathrm{Sr}$ & $\begin{array}{l}6.33 \\
E-01\end{array}$ & $\begin{array}{c}1.71 \\
E+01\end{array}$ & $\begin{array}{c}2.70 \\
E+00\end{array}$ & $\begin{array}{c}6.33 \\
E+00\end{array}$ \\
\hline${ }^{90} Y^{*}$ & $\begin{array}{l}6.33 \\
E-01\end{array}$ & $\begin{array}{c}1.71 \\
E+01\end{array}$ & $\begin{array}{c}0.00 \\
E+00\end{array}$ & $\begin{array}{c}0.00 \\
E+00\end{array}$ \\
\hline${ }^{137} \mathrm{Cs}$ & $\begin{array}{l}4.18 \\
E-01\end{array}$ & $\begin{array}{c}1.13 \\
E+01\end{array}$ & $\begin{array}{c}1.35 \\
E+01\end{array}$ & 8.37 E-01 \\
\hline${ }^{137 m} \mathrm{Ba}^{*}$ & $\begin{array}{l}3.96 \\
E-01\end{array}$ & $\begin{array}{c}1.07 \\
E+01\end{array}$ & $\begin{array}{c}0.00 \\
E+00\end{array}$ & $\begin{array}{c}0.00 \\
E+00\end{array}$ \\
\hline${ }^{154} \mathrm{Eu}$ & $\begin{array}{r}1.06 \\
\text { E-02 }\end{array}$ & 2.86 E-01 & $\begin{array}{c}1.35 \\
E+01\end{array}$ & $2.12 \mathrm{E}-\mathrm{O} 2$ \\
\hline Total & --- & $\begin{array}{c}5.65 \\
E+01\end{array}$ & ---- & $\begin{array}{c}7.21 \\
E+00\end{array}$ \\
\hline
\end{tabular}

*Daughter product. 
HNF-2761, Rev. 0

This page intentionally left blank.

A3-2 
HNF-2761, Rev. O

\subsection{TRANSPORTATION SYSTEM}

\subsection{TRANSPORTER}

The conveyance shall have a capacity of $5450 \mathrm{~kg}(12,000)$ or greater and shall have a wooden deck $2.4 \mathrm{~m}(8.0 \mathrm{ft})$ wide and at least $7.6 \mathrm{~cm}(3.0 \mathrm{in}$.) thick. If a deck other than this is used, the shipper shall be responsible for designing the tiedown system to provide resistance to load shifting no less than that specified in this section.

\subsection{TIEDOWN SYSTEM AND CARGO CONFIGURATION}

The following requirements are from Part B, Section 10.0, "Tiedown Evaluation."

a. The lifting bails on the box lid shall not be used to lift the package or to secure it to the vehicle.

b. The package shall be centered from side to side on the conveyance with its length in the direction of travel. Blocking capable of resisting a horizontal force of $2730 \mathrm{~kg}$ $(6,000 \mathrm{lb})$ shall be positioned on both sides of the box. The blocking shall consist of $2 \times 6$ lumber $10 \mathrm{ft}$ long, two per side, nailed through the $7.6-\mathrm{cm}(3.0-\mathrm{in}$.$) deck of the$ vehicle. The blocking shall be fastened to the deck using $20,50 \mathrm{~d}$ common nails (5.5 in. long, $0.244 \mathrm{in}$. in diameter) every $15.2 \mathrm{~cm}(6.0 \mathrm{in}$ ); this requires 20 nails on each side of the package. As an alternative to blocking, the package may be set on a rubberized load mat to increase frictional resistance. To ensure maximum resistance to internal loading, the deck of the conveyance and bottom of the package must be clean, dry, and free of oil and debris. The load mat must have a surface area no less than the bottom of the entire box.

c. Two synthetic web straps shall pass side to side over the package to provide vertical and tipping restraint. The straps shall have a working load limit of $1,360 \mathrm{~kg}(3,000 \mathrm{lb})$ or greater, and they shall be fastened to the sides of the deck at points capable of resisting a force of $1360 \mathrm{~kg}$. All slack shall be removed.

d. One or two chains shall provide longitudinal restraint. The chain shall be size 5/16-in., grade 7 transport chain or other having a working load limit of greater than $1,925 \mathrm{~kg}$ $(4,243 \mathrm{lb})$.

Figure A4-1 shows the configuration and details. 
Figure A4-1. Truck Loading Arrangement and Details.
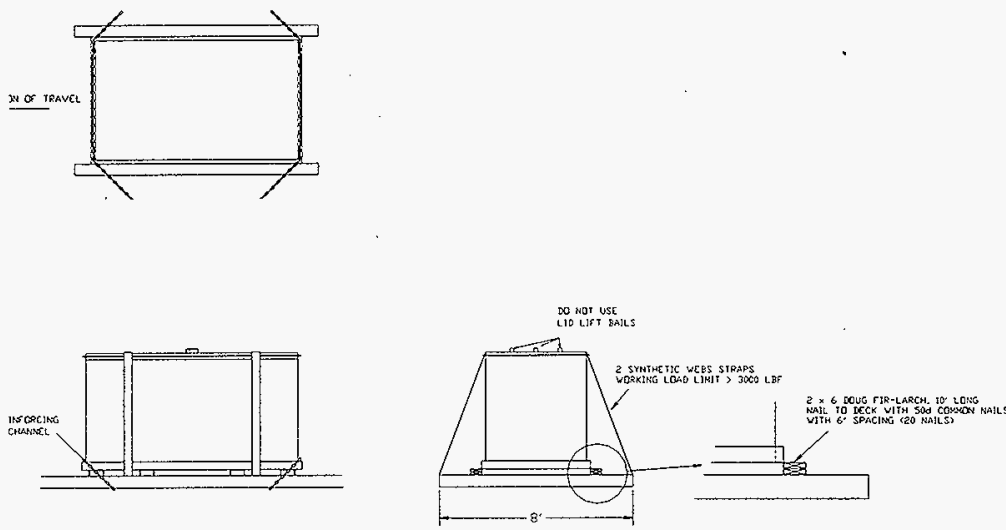

\subsection{SPECIAL TRANSFER REQUIREMENTS}

\subsubsection{Routing and Access Control}

The Pacific Northwest HEPA Filter Box may only be transported from the Hanford 300 Area to the Hanford 200 West Area for disposal. The route from the 300 Area to the Wye Barricade shall be by Route 4 South, and road closure is required for that segment. The route from the Wye Barricade to the 200 West Area shall be by Route 4 South and Route 3, and road closure is not required.

\subsubsection{Radiological Limitations}

For transportation purposes, the dose rate at the external surface of the Pacific Northwest HEPA Filter Box is limited to $2 \mathrm{mSv} / \mathrm{h}$ (200 mrem/h) (49 CFR 173.441) without special provisions. The dose rate in the occupied space of the truck cab shall not exceed $0.02 \mathrm{mSv} / \mathrm{h}(2 \mathrm{mrem} / \mathrm{h})$ if the driver is not a radiological worker or $0.05 \mathrm{mSv} / \mathrm{h}(5 \mathrm{mrem} / \mathrm{h})$ if the driver is a Hanford radiological worker. Supplemental shielding is allowed at the vehicle cab to maintain the dose rate at acceptable levels.

Surface contamination limits for the outside of the box are specified in Table A4-1. 
Table A4-1. External Container Contamination Limits.

\begin{tabular}{|l|c|c|}
\hline \multicolumn{1}{|c|}{ Contaminant } & \multicolumn{2}{|c|}{ Maximum permissible limits } \\
\cline { 2 - 3 } & $\mu \mathrm{Ci} / \mathrm{cm}^{2}$ & $1 \mathrm{dpm}^{-5} \mathrm{~cm}^{2}$ \\
\hline $\begin{array}{l}\text { Beta-gamma emitting radionuclides; all radionuclides with } \\
\text { halt-jives less than ten days; natural uranium; natural } \\
\text { thorium; uranium-235; uranium-238; thorium-232; thorium- } \\
228 \text { and thorium-230 when contained in ores or physical } \\
\text { concentrates }\end{array}$ & 22 \\
\hline All other alpha emitting radionuclides & & \\
\hline
\end{tabular}

Source: 49 CFR 173.443, "Shippers -- General Requirements for Shipments and Packagings," Code of Federal Regulations, as amended.

\subsubsection{Speed Limitations}

The risk evaluation does not impose a more restrictive speed limit than the normal highway speed of $88.5 \mathrm{~km} / \mathrm{h}(55 \mathrm{mph})$. During intersection type turns, speed shall be limited to $8 \mathrm{~km} / \mathrm{h}$ (5 mph) maximum.

\subsubsection{Environmental Conditions}

The Pacific Northwest HEPA Filter Box shall not be transported when there is snow or ice on the roadway or when the ambient temperature is below $-12.2^{\circ} \mathrm{C}\left(10^{\circ} \mathrm{F}\right)$. This temperature limit is dictated by the steel used in the inner cavity.

\subsubsection{Frequency of Use and Mileage Limitations}

The mileage shall not exceed $48.3 \mathrm{~km}$ (30 mi). This limits the route to that specified in Part B, Section 4.3.1.

Use of this SEP is limited to a period of 1 year from the date of release. 
HNF-2761, Rev. 0

This page intentionally left blank.

A4-4 
HNF-2761, Rev. 0

\subsection{ACCEPTANCE OF PACKAGING FOR USE}

\subsection{NEW PACKAGING}

No additional packagings will be purchased as the manufacturer has gone out of business.

\subsection{PACKAGING FOR REUSE}

The packaging is not authorized for reuse. 
HNF-2761, Rev. 0

This page intentionally left blank.

A5-2 


\subsection{OPERATING REQUIREMENTS}

\subsection{GENERAL REQUIREMENTS}

The package will be prepared for disposal in accordance with Pacific Northwest-approved operating manuals PNL-MA-8, Waste Management and Environmental Compliance, and PNL-MA-900, Hazardous Material Shipping Manual.

\subsection{LOADING PACKAGE}

The package is currently loaded, and no additional material will be added to the package prior to transport.

\subsection{TRUCK LOADING AND TRANSPORTING}

The box shall be loaded on the transport vehicle in the Hanford 300 Area adjacent to Building 325. The loading operation, except for tiedowns, is beyond the purview of this SEP and is covered by the facility safety analysis report. Therefore, no analysis of a handling accident during loading or unloading was conducted.

The box shall be secured to the vehicle as discussed in Part A, Section 4.0. During transport, no transloading operations shall occur. In case of a vehicle breakdown, the vehicle shall be towed to the destination.

\subsection{UNLOADING PACKAGE}

The box shall be unloaded from the transporter in the Hanford 200 Area either at the Central Waste Complex or a burial site. The HEPA filters are not expected to be removed from the box. If the filters must be removed from the box, the unloading operation is beyond the purview of this SEP and is covered by the facility safety analysis report. Therefore, no analysis of a handling accident during loading or unloading was conducted. 
HNF-2761, Rev. O

This page intentionally left blank.

A6-2 
HNF-2761, Rev. 0

\subsection{QUALITY ASSURANCE REQUIREMENTS}

\subsection{GENERAL REQUIREMENTS}

Since the box was procured and loaded by Pacific Northwest, quality assurance (QA) requirements related to design, procurement, fabrication, and use of the box are based on Pacific Northwest's hazardous material shipping program as described in PNL-MA-900 and to applicable portions of PNL-MA-70, QA Manual.

Pacific Northwest shall be responsible for all activities related to any repair of the box that may be necessary to allow the box to be safely transported.

Pacific Northwest shall be responsible for shipping the box in compliance with a Pacific Northwest-approved safe operating procedure, the requirements specified in this SEP, and those requirements contained in PNL-MA-81.

\subsection{SEP CONTROL SYSTEM}

The Pacific Northwest HEPA Filter Box SEP shall be a supporting document that is valid for 1 year from the date of release. SEP changes shall be provided as engineering change notices and shall be provided to all holders of this SEP. SEP review records (comments) shall be retained by the organization responsible for this SEP, currently the Engineering group of Waste Management Federal Services, inc., Northwest Operations, for the life of the system. These records are not considered QA records, but provide historical evidence of SEP review and approval. 
HNF-2761, Rev. 0

This page intentionally left blank.

A7-2 
HNF-2761, Rev. 0

\subsection{MAINTENANCE}

Due to the single-use nature of the Pacific Northwest HEPA Filter Box and the 1-year limit on this SEP, there are no maintenance requirements for either the container or associated tiedown hardware. Should a repair be necessary to transport the box, the repairs will be conducted in accordance with Pacific Northwest procedures listed in Part A, Section 7.1. Pre-use inspections for tiedown hardware are covered in Part A, Section 4.2. 
HNF-2761, Rev. 0

This page intentionally left blank: 
HNF-2761, Rev. 0

\subsection{REFERENCES}

49 CFR 173, 1994, "Shippers-General Requirements for Shipments and Packagings," Code of Federal Regulations, as amended.

49 CFR 393, 1994, "Parts and Accessories Necessary for Safe Operation," Code of Federal Regulations, as amended.

AWS, 1989, Structural Welding Code--Steel, ANSU/AWS D1.1-89, American Welding Society, Miami, Florida.

HNF-PRO-154, Responsibilities and Procedures for all Hazardous Material, Fluor Daniel Hanford, Inc., Richland, Washington.

HNF-PRO-157, Radioactive Material/Waste Shipments, Fluor Daniel Hanford, Inc., Richland, Washington.

HNF-PRO-163, Documentation and Record Keeping, Fluor Daniel Hanford, Inc., Richland, Washington.

HNF-PRO-166, Transportation Safety Training Requirements, Fluor Daniel Hanford, Inc., Richland, Washington.

PNL-MA-8, Waste Management and Environmental Compliance, Pacific Northwest National Laboratory, Richland, Washington.

PNL-MA-70, OA Manual, Pacific Northwest National Laboratory, Richland, Washington.

PNL-MA-900, Hazardous Material Shipping Manual, Pacific Northwest National Laboratory, Richland, Washington.

Willis, N. P., 1993, Hanford Site Solid Waste Acceptance Criteria, WHC-EP-0063-04, Westinghouse Hanford Company, Richland, Washington. 
HNF-2761, Rev. 0

This page intentionally left blank. 


\title{
10.0 APPENDICES
}

\subsection{PACIFIC NORTHWEST HEPA FILTER CHECKLISTS}

\author{
PNL HEPA FILTER DISPOSAI. CHECKI.IST \\ i. 0,04
}

In order to properly disfese of HEPA filters, (hereafter. refarred to as

filters), the wate gererator is requiled to complete ibe folloiting checklist.

Proper records inanagenent of the criginal completed cliccklist shall be the responsibility of the waste generatcr. The completed checklist shall be sent to the cognizant Waste Kenagement Section staff niember (currently Rene $L$. Jones, MSIN P7-79, 376-2061) for approvel before disposing of filter.

The completion of one checklist for each filter to te disposed is generally required. If a bank of filters that serviced the sanie laboratories/roons are to be disposed in the sane waste container, one checklist may suffice for the entire filter bank if it can be shohn that the constituents of all filters included is identical.

\section{SECTION A - WASTE GEMEPATO?}

1. Name: P. J. GACTHER

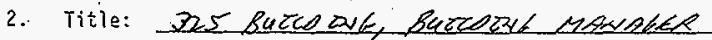

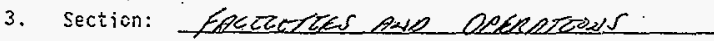

4. Department: EACEZEY OPERALcover

5. HSIN:

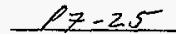

6. Phone Number: $376-5746$

- Section B - HEFA FIITES UISTORY

1. Lecation of iliter liten in service:
a) Area: 300
b) Euilding: 325
c) Specific lecation: Peon $23-2$
d) Exhaust.siće? [X] Yes
e) Supply side? [X] yes
[ ] $1 \mathrm{No}$
[ ] NO/ $R / C$ UWET HOR
2. Physical. characteristics of filter Moom 23, 23/ Pxp 209

a) Filter designation (unique number or name assigned to filter to prasforay

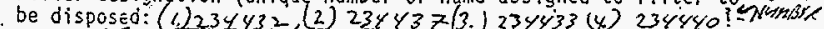

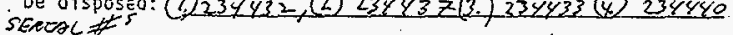

b) Number of ititers iaciuded in this checklist: OA Reria of Aruts

c) Filter dibensions: TOS $5 \times 5$ Nates To vesecoy Als MEAin

FILTER DISPOSALL CHECKLIST (PAGE I OF 4) 
HNF-2761, Rev. 0

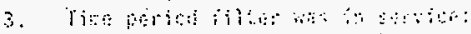

a) Dato instaled: .... 9-1-93

b) Dáte renioved:

4. Reason for chérigeout:

W Particulate loading (exceeced differential pressure limits)

[) Radionuclide loading (exceeded established dose rate limit)

() Leak in filter (fajlure to pass leak test)

] Regularly scheduled iH (preventative maintenance)

[) Other (please specify):

5. Identify all laboratories/rooms that exhausted through the illter(s) to be oisposed ard identify all operations and/or experiants which could have cerierated hezareus riaterials or radionuclides that occurred in tite leboratories/rooms upstrean of the filter(s) during the tine the filter(s) was in use.

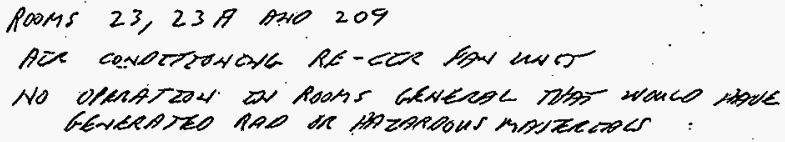

Section C - RADIOHUCLIGE CHARACTERIZATIOU

1. Is there a potential that the operations that eccurred upstram of the filter(s) could have released radionuclides that are now currently trepped in the filter(s)?

[ ] Yes. Hote: Generally, ine criteria for installing HEPA filtration in a facility exheust systen is that cperations occurrire ustrean of the fiEfA filter have the potential to

D) release airborie radoniclices.

2. Method used to characterize raojionuclices:

8
[]
[]

Process krew?ecse

Haterial bajance

Non-destructive analysis (NDA)

J Sampling and analysis

I Other, please describe:

3. Based on the radionuclide charecterization methodology chosen in question 2, 7 ist below all radionuclides (qualitatively and quantitatively) knoin to be present in the filter.

$i / A$

FILTER DISPOSAL CHECKLIST (PAGE 2 OF 4) 
HNF-2761, Rev. 0

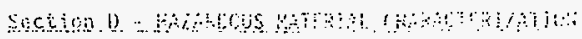

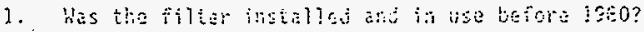

$\infty 110$

[] Yes. Hote: Hepa filters installed before ] 980 generally contrin $>01$ wejght percent of di-octyl phthalate, a hazardous. niicterial.

2. Is there a potential that the operations or experiments that occurred upstram of the filter(s) to be disposed could have released hazarcous materials (or chemicals that combined to form a hazardous siaterial) that are rois currently trapped in the filter? [Process krowledge oualitative datä]

(x) No

[] Yes. Please itemize hazzarouds materials:

2. a Did processes which grind, saw, boil, distill or otterwise result in generation of airborne particulates or vapors eccur upstrean of the filter?

Dio

[ ] Yes.

Pleáse itemize hazarcious mâterials:

2.b When removed fron service did the filter(s) and/or cuctwork show signs of̂ condensation?

X] kio

[ ] Yes, Contect Waste Henecsment.

3. Based on the knowlecge of the cperations or experiments that were conducted and information known regarding the release of hazardous materials to the filter(s) in question, is it possible to determine the concentration of each hazarovos aaterial irapped in the

filter(s) to be disposed? [f:ocess krowedge cuentitetive data]

E) N/A (Filter does not contain hazardous material),

[] No. Filter must be analyzed.

Yes. Please list each hazaroous material with concentration (expressed in terms of mass of hazardous material per mass or volume of filter medium).

FiLIER DISPOSAL CHECKLIST (PAGE 3 OF 4) 


\section{sectinin r. Un:}

\section{BEST AVAILABLE COPY}

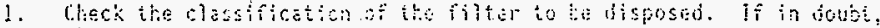
piease consule with biaste fanagenent.

\begin{tabular}{|c|c|c|c|}
\hline & oactive & liazarions & centact \\
\hline & Ho & lio & RL Johes $376-286 \mathrm{I}$ \\
\hline [V] & Yes & Ho & IL jones 376-2861 Met able te release \\
\hline [ ] & Yes & ies & W Riess $372-3517$ as Mor \\
\hline [ ] & No & YES & SP Juracich 372.0524 \\
\hline
\end{tabular}

Prior to filter disposal, please send this completed form to Haste Managenent (Rene L. Jones P7-79). Original completed forms will be returned ard shall be kept on file by the k'aste Generator.

I certify the above classification is correct according to information given in sections A-D.
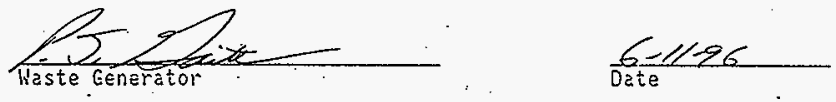

I have reviewed the above classitication and ind it to be correct according to information given in sections $A-D$.

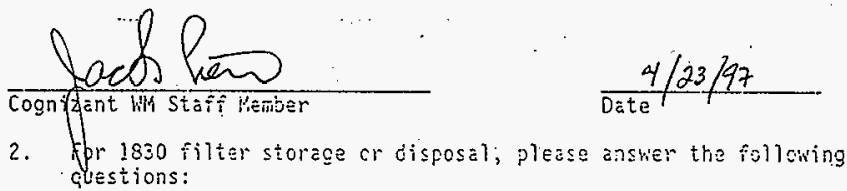

a) Storage/Disposal Approval Recoro (SDAR) number:

1

b). Package. ldentification liumber (PIN):

3. For 1831 filter disposal, please answer the following question:

a) Packäe Identification lúmer (PIN)

FILTER DISPOSAL CHECKLIST (PREE 4 OF 4) 
HNF-2761, Rev. O

\section{of butruedunchedente}

\section{PNL FILTER DISPOSAL CHECKLIST}

Prepared by Waste Management \& Environmental Compliance

Last revision $11 / 12 / 90$

In order to properly dispose of HEPA filters, prefilters, and duststops, (hereafter referred to as filters), the waste generator is required to complete the following checklist. The purpose of this checklist is to document the characterization methodologies employed to determine the radionuclide and hazardous material content (both qualitative and quantitative) of the filter to be disposed.

The completion of one checklist for each filter to be disposed is generally required. If a bank of filters that serviced the same laboratories/rooms are to be disposed in the same waste container, one checklist may suffice for the entire filter bank if it can be shown that the constituents of all filters included is identical.

The Westinghouse Hanford Company currently does NOT require that this checklist accompany the waste for storage or disposal. Proper records management of the original completed checklist shall be the responsibility of the waste generator. A photocopy of the completed checklist shail be sent to the cognizant Waste Management \& Environmental Compliance Section staff member (currently: ruce $\mathrm{W}$. Killand, MSIN 97-68, 376-3158). This completed checklist (or a photocooy thereof) wili serve as the documented characterization of the contents of the firter, and will be reviewed by the Westinghouse Hanford Company during the ir annual assessment of PNL's radioactive waste management practices. Questions regarding the completion of this checklist shall be directed to 8ruce $H$. Killand on $376-3158$ :

Section A - WASTE GENERATOR

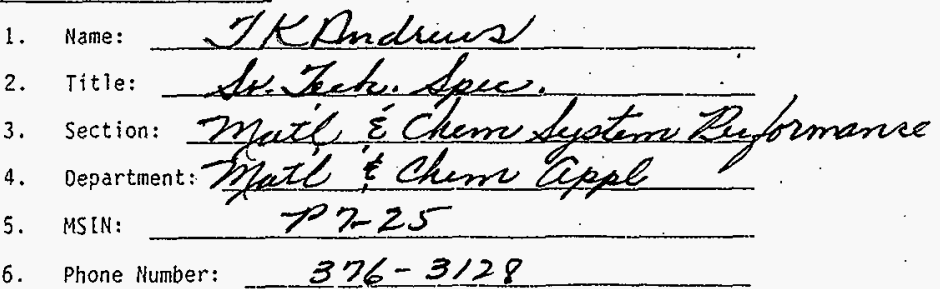

FILTER DISPDSAL. CHECKL.IST (PAGE \& OF B) 
HNF-2761, Rev. O

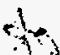

\section{Section 8 - HEPA FILTER HISTORY}

1. Location of filter when in service:
a) Area:
300
b) Building: 325

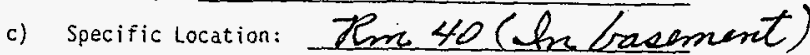
d) Exhaust side? [V Yes [ ] No
e) Supply side? [] Yes [U Ho
Note: $i f$ the filter to be disposed is a supply side dust stop or pre-filter with no possibility of being contaminated with radionuclides or hazardous material, the filter should be disposed of in the normal trash destined for the Central Landfill (between the 400 area and the 200 area).

2. Physical characteristics of filter
a) Filter designation (unigue number or name assigned to filter to

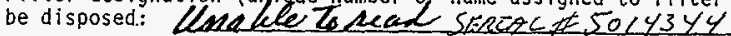
b) Number of filters included in this checklist: 4
c) Filter dimensions: $\frac{24 \times 24 \times 20^{\prime \prime}=45 / 8 \text { metal }}{\text { teuctenges }}$

3. Time period filter was in service:
a) Date installed:
zet knowri
b) Date removed:

4. Reason for changeout:

[ ] Particulate loading (exceeded differential pressure limits) Radionuclide loading (exceeded established dose rate limit) Leak in filter (failure to pass leak test) Regularly scheduled PM (preventative maintenance) other (please specify):

FILTER DISPOSAL CHECKLIST (PAGE 2 OF 8) 
HNF-2761, Rev. 0

5. Identify all laboratories/rooms that exhausted through the filter (s) to be disposed. 325 A Shudder Ge el Facility "C"Cll

6. When available, identify all operations and/or experiments which could have generated hazardous materials or radionuclides that occurred in the laboratories/rooms upstream of the filter (s) during the time the filter(s) was in use.

Euapum/Stodinium/Poject

FILTER DISPOSAL CHECK. TS (PAGE 3 DF 8)

A10-7 
HNF-2761, Rev. O

\section{Section C - RAOLONUCLIDE CHARACTERIZATION}

1. Is there a potential that the operations that occurred upstream of the iilter(s) could have released radionuclides that are now currently trapped in the filter(s)?
[Y Yes. Note: Generally, the criteria for installing HEPA filtration in a facility exhaust system is that operations occurring upstreafl of the HEPA filter have the potential to release airborne radionuclides.

[] No

2. Method used to characterize radionuclides:

[1 Process knowledge. Process knowledge is employed as a radionuclide characterization method when a given quantity (and resulting concentration) of specific radioactive material is known to be contained within a given waste. This method is also used to determine the absence of particular radionuclides. For example, if the operations or experiments that were conducted upstrean of the filter involved only $\mathrm{Sr}-90$, there is no need to measure the filter for other isotopes.

[ 1 Material balance. Material balance is valid as a radionuclide characterization method when a given quantity (and resulting concentration) of a specific radionuclide is inferred by determining the difference between the quantity of radioactive material entering and exiting a given process. An example of the use of this method would be a laboratory in which known amounts of radioisotopes are used for research activities, the waste from which is ultimately disposed of as radiaactive waste.

[ ] Non-destructive analysis (NDA). Non-destructive analysis involves directly measuring the radiation emitted by the radioactive material in the waste. (Note: for a complete description of NDA capabilities and limitations at PNL, please contact Ron Brodzinski.)

[.] Sampling and anaiysis, When no other data exist or can be inferred, representative samples of the filter must be analyzed. The relative concentration of all the radionuclides is obtained from this method. This method is most frequently used when a qualitative assessment of the radionuclides is impractical.

[ ] Other, please describe.

FILTER DISPOSAL CHECXLIST (PAGE 4 OF 8) 
HNF-2761, Rev. 0

3. Based on the radionuclide characterization methodology chosen in question 2, 1 ist below all radionuclides (qualitatively and quantitatively) known to be present in the filter. Note: Each radionuclide that contributes more than $1 \%$ of the total activity present in the filter to be disposed must be identified and quantified, as well as any decay products if they exceed $1 \%$ of the total activity. Naturally occurring radioisotopes should be reported if they are the reason the waste is being declared radioactive, or if they have been enriched in any way. However, if these isotopes are incidental to fission or activation products that cause the waste to be declared radioactive, then the naturally occurring radioisotopes need not be reported.
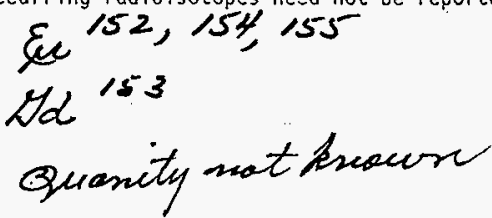

FILTER DISPOSAL CHECKLIST (PAGE 5 DF. 8) 
HNF-2761, Rev. 0

\section{Section D - HAZAROOUS MATERIAL CHARACTERIZATION}

The physical/chemical constituents trapped in the filter must be deternined in order to ensure that the filter contains no RCRA hazardous waste. If operations or experiments upstream of the filter generated hazardous materials that could possibly reach the filter, then a determination must be made if process knowledge can identify and quantify these chemicals for the purposes of performing a waste designation. If process knowledge is not adequate, the contents of the filter must be sampied and analyzed.

1. Is there a potential that the operations or experiments that occurred upstream of the filter( $s$ ) to be disposed could have released hazardous materials (or chemicals that combined to form a hazardous material) that are now currently trapped in the filter? [Process knowledge qualitative data]

[r] No

[] Yes. Please itemize hazardous materials:

2. Based on the knowledge of the operations or experiments that were conducted and information known regarding the release of hazardous materials to the filter(s) in question, is it possible to determine the concentration of each hazardous material trapped in the filter(s) to be disposed? [Process knowledge quantitative data] [ $[$ N/A (Filter does not contain hazardous material)

Yes. Please list each hazardous material with concentration (expressed in terms of mass of hazardous material per mass or volume of filter medium).

FILTER DISPOSAL CHECXLIST (PAGE 6 OF 8) 
3. If the answer to question 1 above is yes, and the answer to question 2 above is no, the contents of the filter must be sampled and analyzed for hazardous material content. Sampling and analys is of filter(s) must be handled on a case-by-case basis. Please contact WMEEC (8W Killand on 376-3158) for further guidance.

4. If the answer to questions 1 and 2 above is yes, and it has been decided that the filter(s) to be disposed contains mixed waste (waste containing radioactive constituents plus hazardous constituents), fill out a Chemical Disposal/Recycle request form and submit to WM\&EC (KB Selby on 376-7233, MSIN P7-68) for the disposal of mixed waste.

5. If the answer to question 1 above is no, and the filter is assumed to be radioactive, it can be disposed as lowmlevel waste. Contact WMEC (Bruce $\mathrm{W}$. Kill and on 376-3158).

6. Summary (check one of the following):

[M] Filter contains radioactive, non-hazardous waste. Contact BW $\mathrm{Kill}$ and on $376-3158$.

[ ] Filter contains radioactive, hazardous (with KNOWN constituents \& concentrations) waste. Contact KB Selby on 376-7233.

[ ] Filter contains radioactive, hazardous (with UNKNOWN constituents \& concentrations) waste. Contents. of filter must be analyzed. Contact BW Killand on 376-3158.

[ ] Filter contains non-radioactive, non-hazardous waste (i.e. supply side dust stop filter). Regular trash to Hanford Central Landfill or Richland l.andfill.

mylias $3 / 17 / 95$

$\rightarrow$ meed date of indallation to ensure that DOP is motuan wowe 
HNF-2761, Rev. 0

Section E - WASTE HANDLING, PACKAGING, AMD SHIPPING RECOROS.

1. Check the destination of the filter to be disposed. If in doubt, please consult with WM\&EC (BW Killand on 376-3158).

[ ] Hanford Central Landfill (Non-radioactive, non-hazardous waste generated in areas other than 3000 area)

[ ] Richland Landfill (Non-radioactive, non-hazardous waste

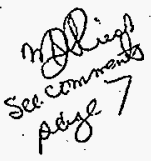
generated in the 3000 area)

Low-level Waste burial grounds (Radioactive, non-hazardous waste generated by 1830 funded research)

US Ecology (Radioactive, non-hazardous waste generated by 1831 funded research)

[ ] Central Waste Complex (Mixed waste generated by 1830 funded research)

[ ] 3058 (Non-radioactive, hazardous waste generated in areas other than 3000 areas)

[ ] MRC (Non-radioactive, hazardous waste generated in the 3000 area)

[] other, please specify:

2. For filter storage or disposal via Westinghouse Hanford Company's Low-level Waste Burial grounds (low-level waste) or the Central Waste Complex (mixed waste), please answer the following questions:

a) Storage/Disposal Approval Record (SOAR) number:

Note: for filters containing mixed waste, a specific SOAR must be approved by WHC. Contact WM\&EC (Kevin Selby 6-7233) for details.

b) Solid Waste Storage/0isposal Approval (SWSDR) number:

c) Package Identification Number (PIN):

Prior to filter disposal, please return a photocopy of this completed form to Waste Management \& Environmental Compliance (Bruce W. Xilland P7-68). Original completed forms shal) be kept on file by the Waste Generator.

FILTER DISPOSAL CHECKLIST (PAGE 8 OF 8) 
HNF-2761, Rev. 0

\subsection{PACIFIC NORTHWEST RADIOASSAY REPORT}

Sheet1

Waste Generator - PNNL

Box 1D. PNLD-96-384

NDA Log \# A97042

GW kgs $=\quad 4536.0$

Non-TRU Radionuclides

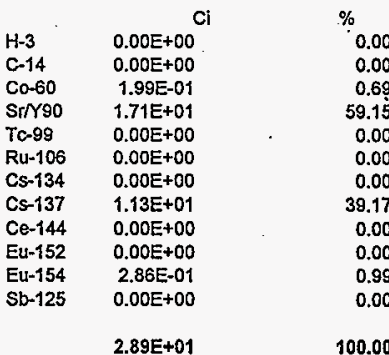

325 Building - 300 Area

TID Number $=$

NA

GW in lbs=

Net Wgt. kgs =

Container Volume

Watts

$0.00 \mathrm{E}+00$

$0.00 \mathrm{E}+00$

$3.06 \mathrm{E}-03$

1.14E-01

$0.00 E+00$

$0.00 E+00$

$0.00 E+00$

$5.34 \mathrm{E}-02$

$0.00 \mathrm{E}+00$

$0.00 E+00$

2.57E-03

$0.00 E+00$

1.73E-01

TRU/Fissile/Source Material Information

Nuclide
Pu238
Pu239
Pu240
Pu241
Pu242
Am241
Cm244
Totals

\section{Pu239}

$$
\text { Grams PE-Ci FGE Alpha Ci nCi/g }
$$

$0.00 E+00 \quad 0.00 E+00 \quad 0.00 E+00 \quad 0.00 E+00 \quad 0.00 E+00$

$\begin{array}{llllll}0.00 E+00 & 0.00 E+00 & 0.00 E+00 & 0.00 E+00 & 0.00 E+00\end{array}$

$\begin{array}{llllll}0.00 E+00 & 0.00 E+00 & 0.00 E+00 & 0.00 E+00 & 0.00 E+00\end{array}$

$\begin{array}{lllllll}0.00 E+00 & 0.00 E+00 & 0.00 E+00 & 0.00 E+00 & 0.00 E+00\end{array}$

$\begin{array}{lllll}0.00 E+00 & 0.00 E+00 & 0.00 E+00 & 0.00 E+00 & 0.00 E+00\end{array}$

$\begin{array}{llllll}0.00 E+00 & 0.00 E+00 & 0.00 E+00 & 0.00 E+00 & 0.00 E+00\end{array}$

$0.00 E+00 \quad 0.00 E+00 \quad 0.00 E+00 \quad 0.00 E+00.0 .00 E+00$

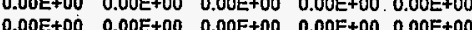

0.00000

TRU Curies =

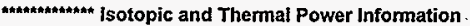

Wt. $\%$ \#DIV/0I \#DIV/0! \#DIV/OI \#DIV/OI \#DIV/0!

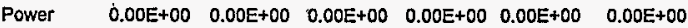

Watts

TRU Thermal Power

0.00000

Watts/m3

0.00000

Category

\section{0}

4286.5

$3.6246 \mathrm{m3}$

CWC

$D E-C i$

$0.00 E+00$

$0.00 E+00$

$1.25 \mathrm{E}-04$

7.35E-02

$0.00 E+00$

$0.00 E+00$

$0.00 \mathrm{E}+00$

$1.09 E-03$

$0.00 E+00$

$0.00 E+00$

2.43E-04

$0.00 E+00$

Sum of

Fractions 0.00

0.00

0.00

294.76

0.00

0.00

0.00

567.87

0.00

0.00

0.11

0.00

7.50E-02

$8.63 E+02$

Total Curies this shipment $\approx$

28.89942

Aro

DE-Ci

$0.00 \mathrm{E}+00$

$0.00 \mathrm{E}+00$

$0.00 E+00$

$0.00 E+00$

$0.00 \mathrm{E}+00$

$0.00 E+00$

$0.00 \mathrm{E}+00$

$0.00 E+00$

Am241 Total Pu

$0.00 \mathrm{E}+00 \quad 0.0 \mathrm{E}+00$ 
HNF-2761, Rev. 0

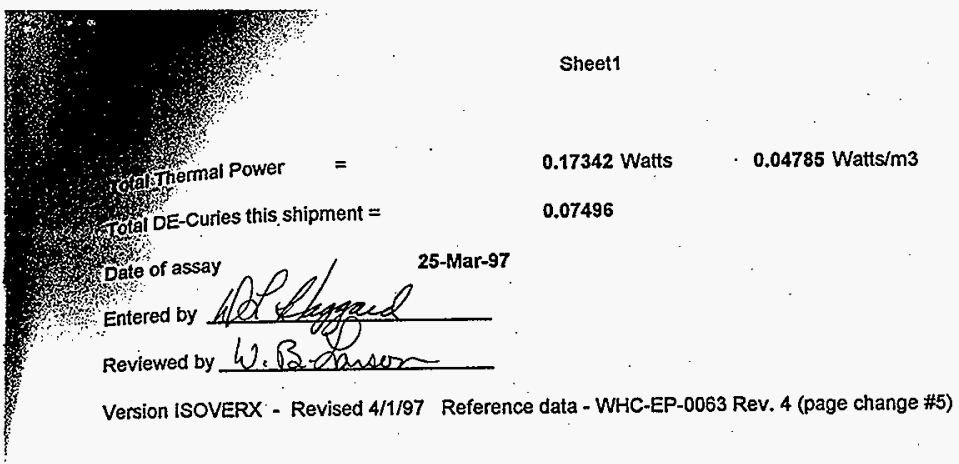

Page 2 
HNF-2761, Rev. 0

10.3 MANUFACTURER DRAWINGS

A10-15 
HNF-2761, Rev. 0

This page intentionally left blank. 


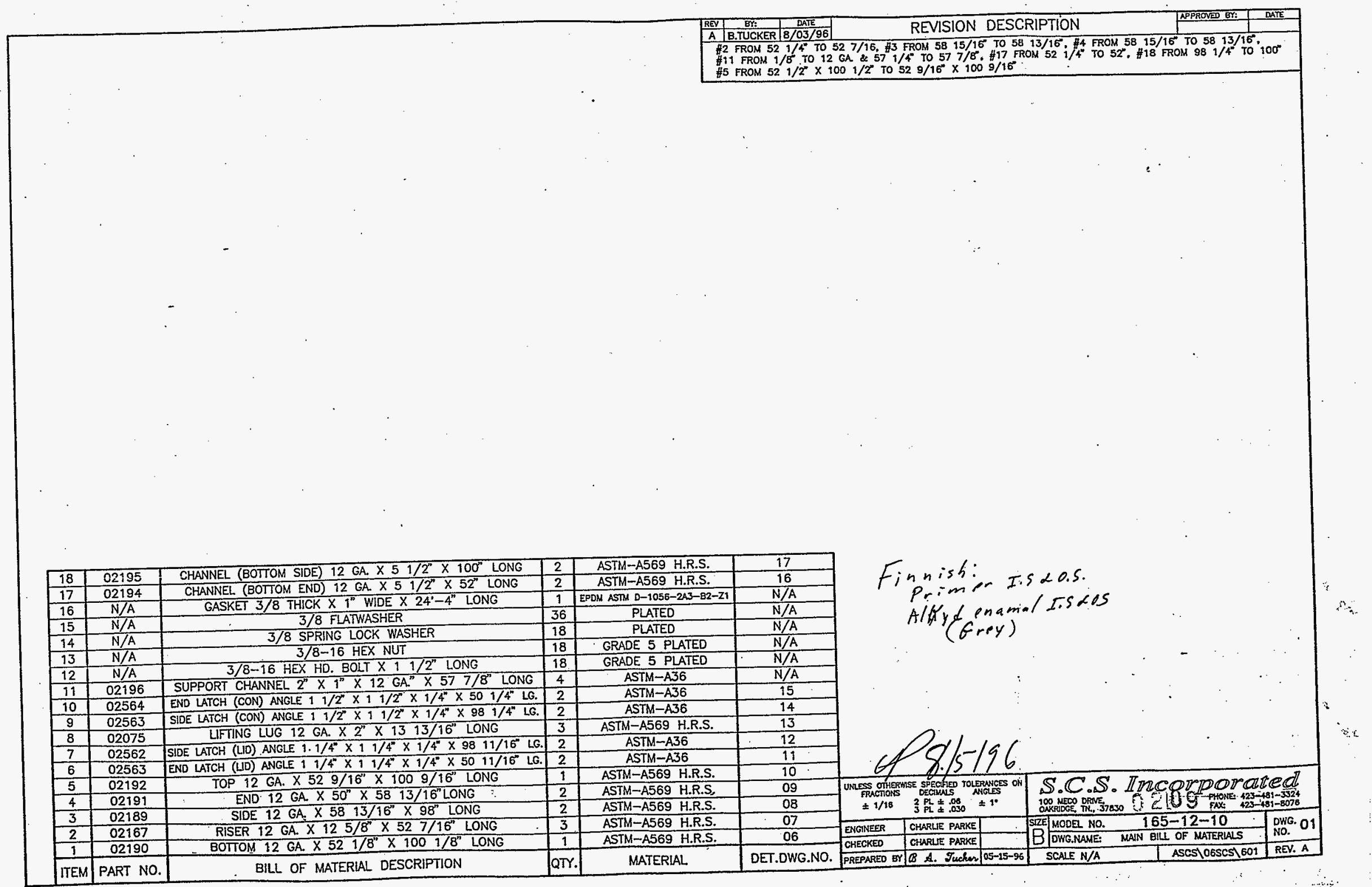

EM PART NO. BILL OF MATERIAL DESCRIPTION 


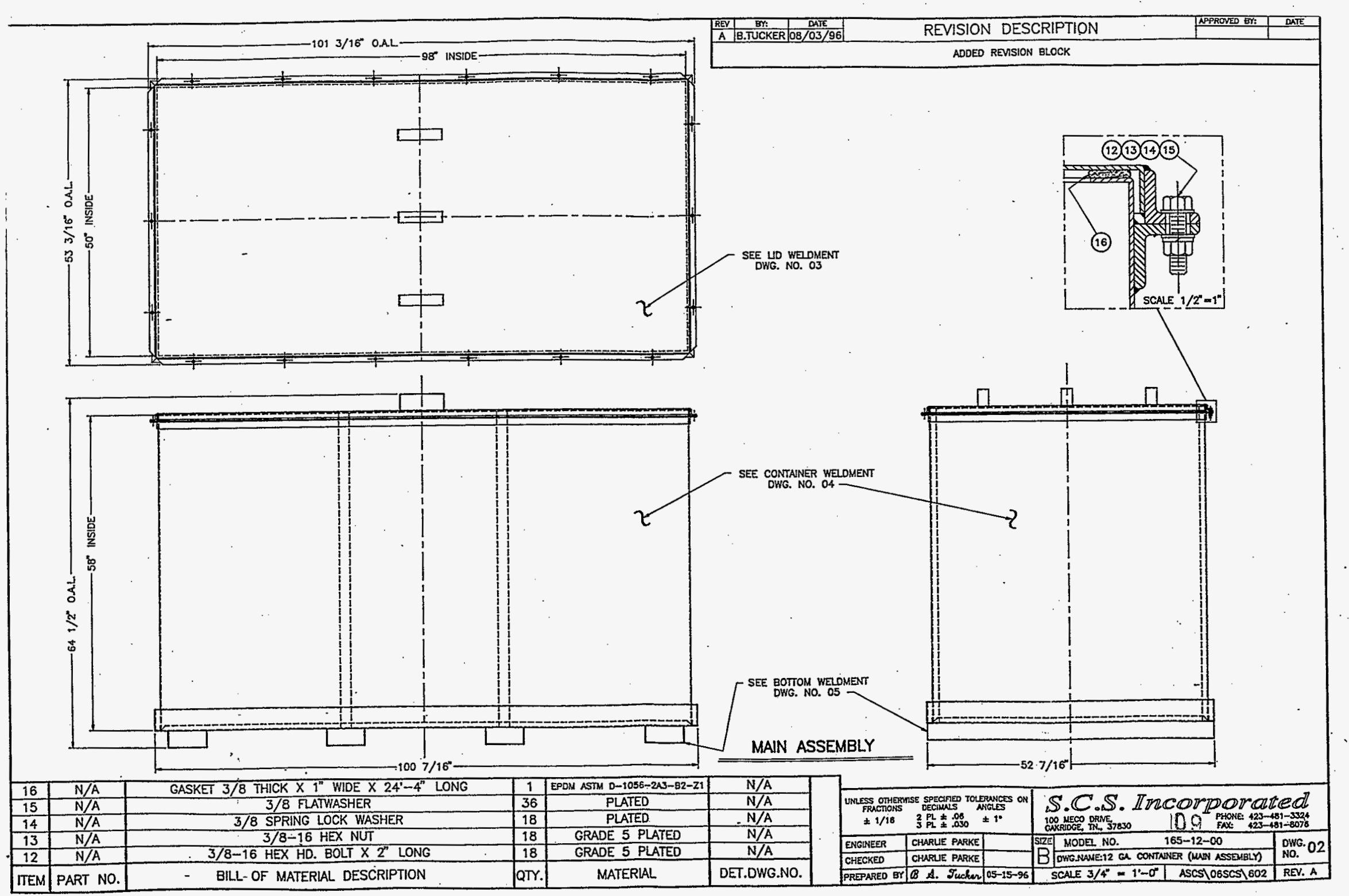




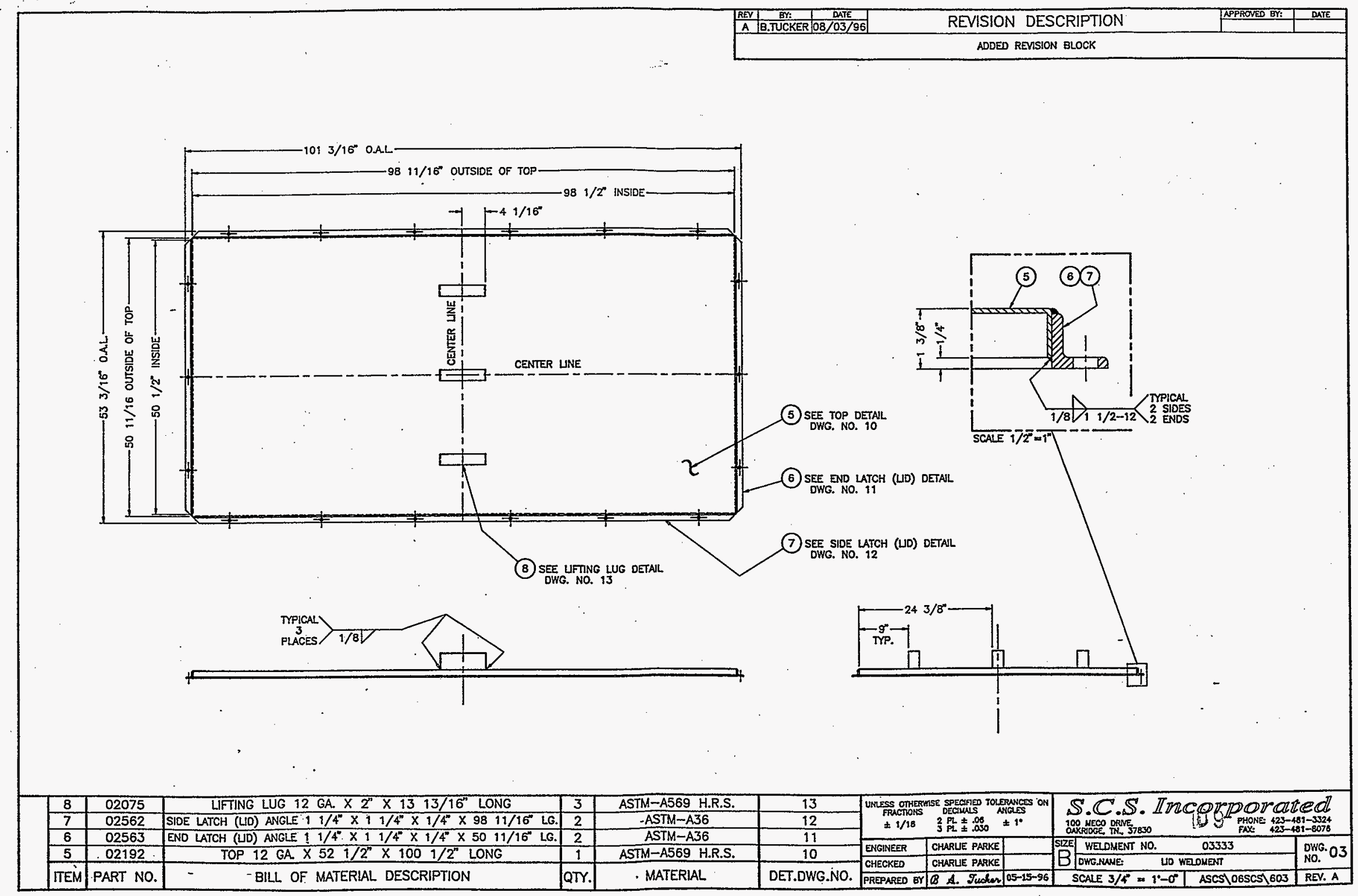




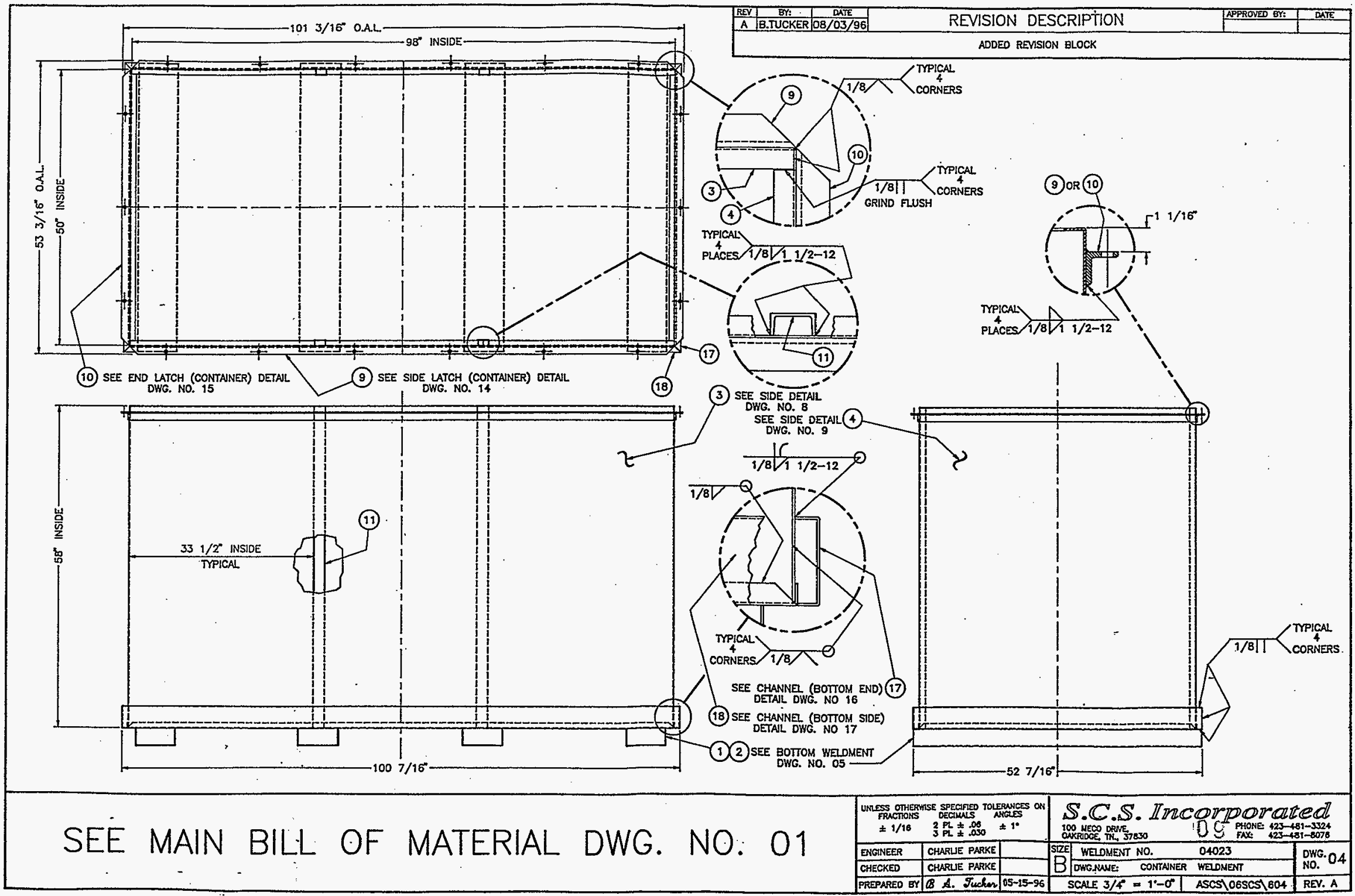


HNF-2761 Rev. 0

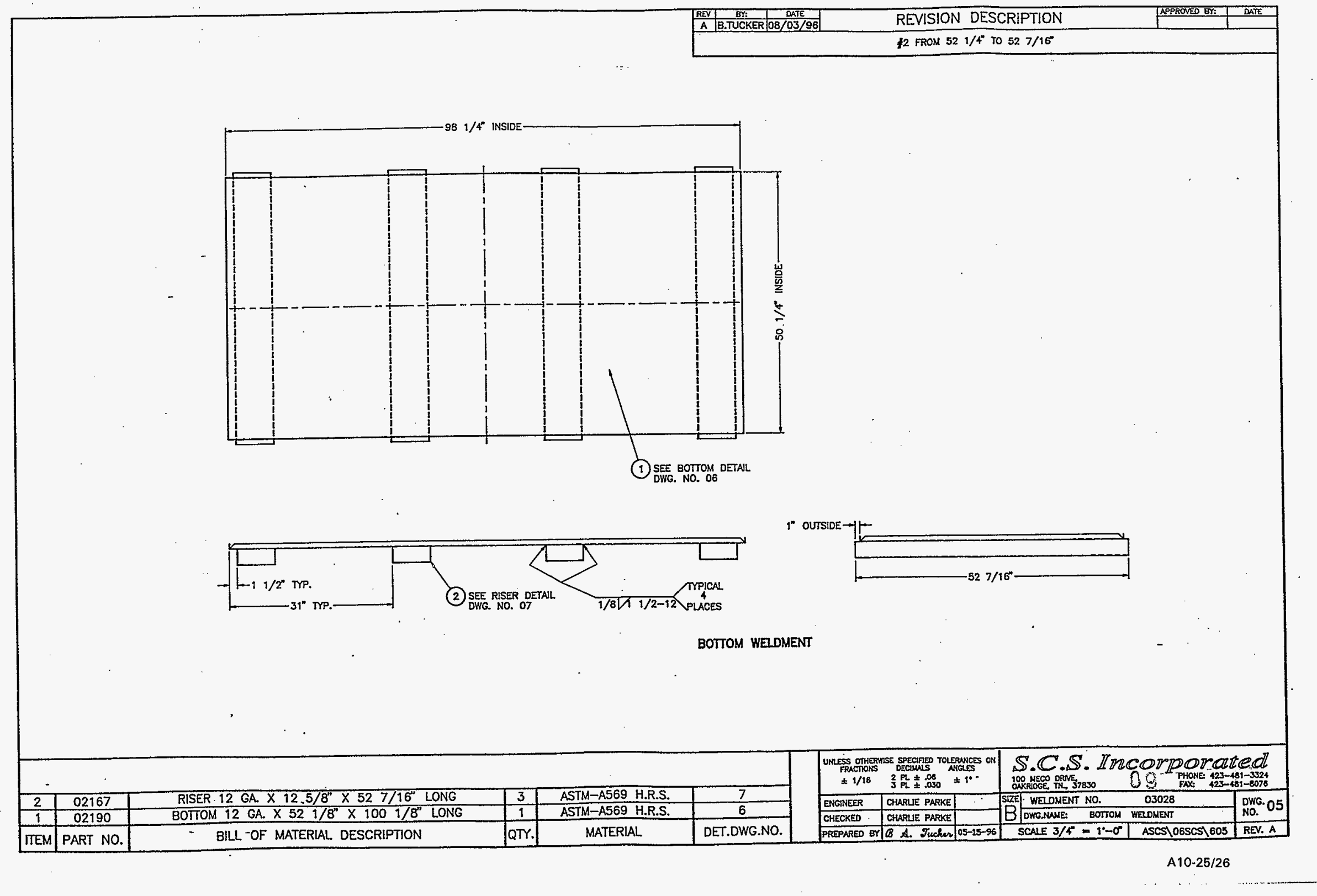




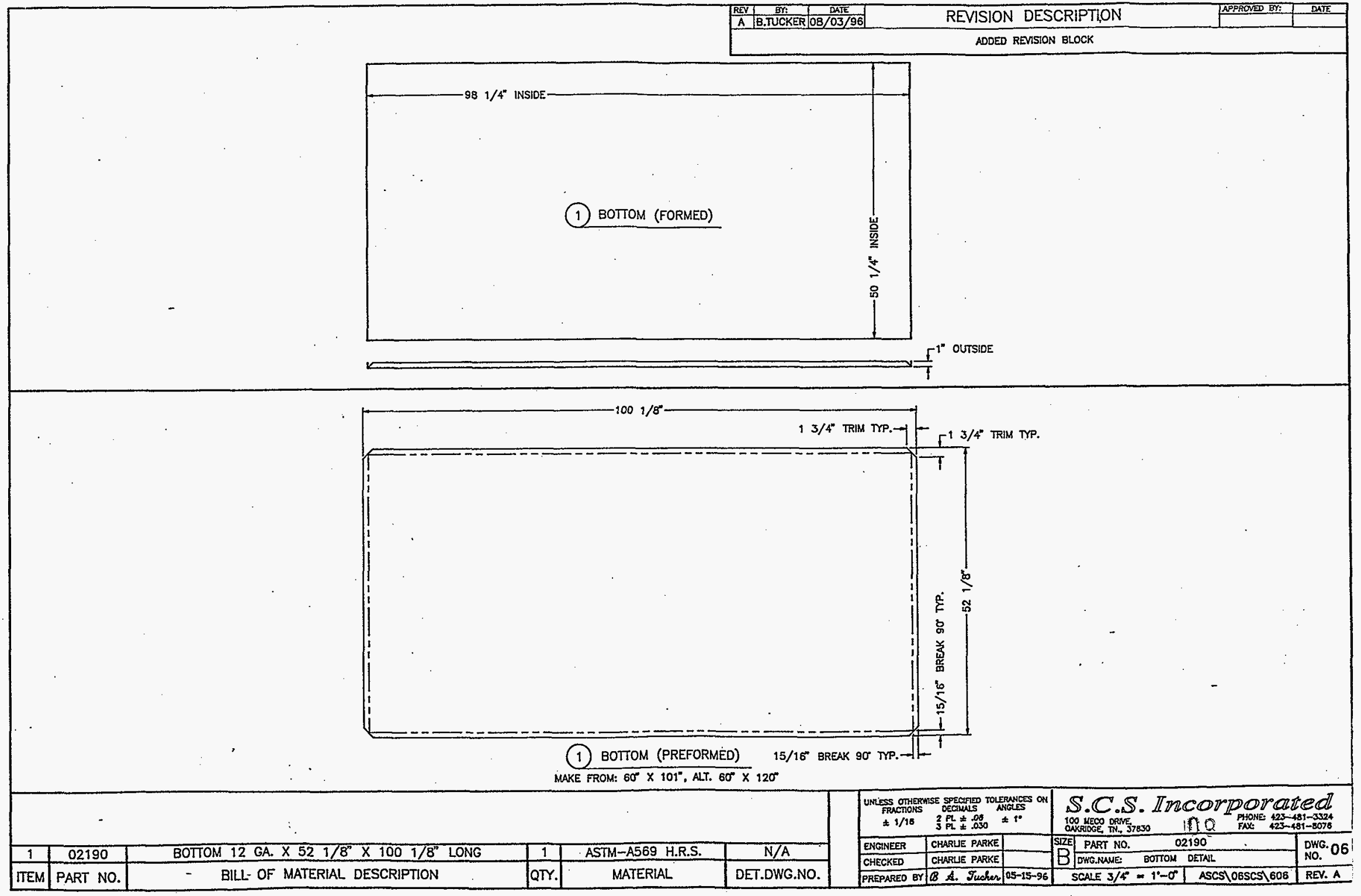




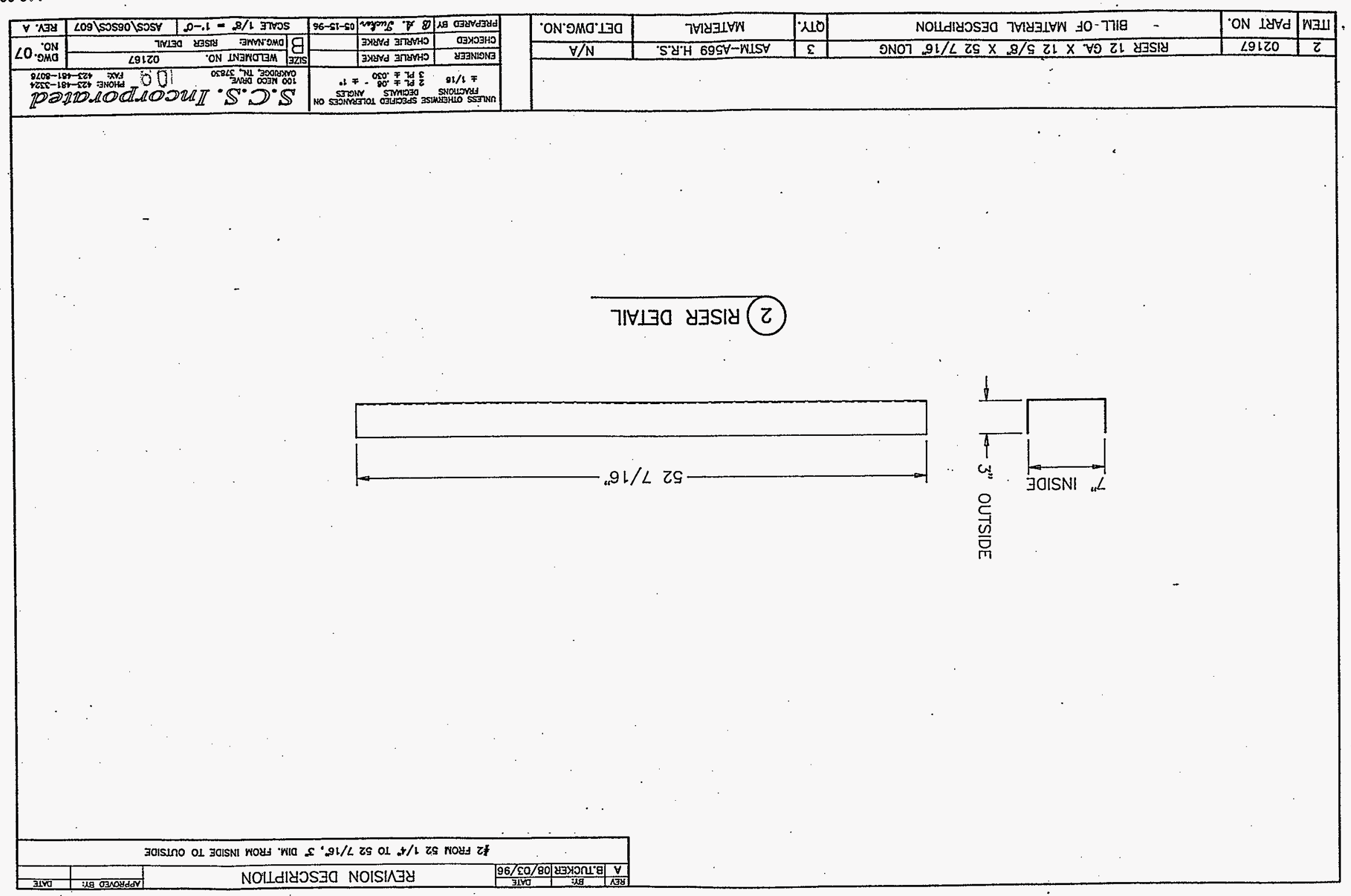




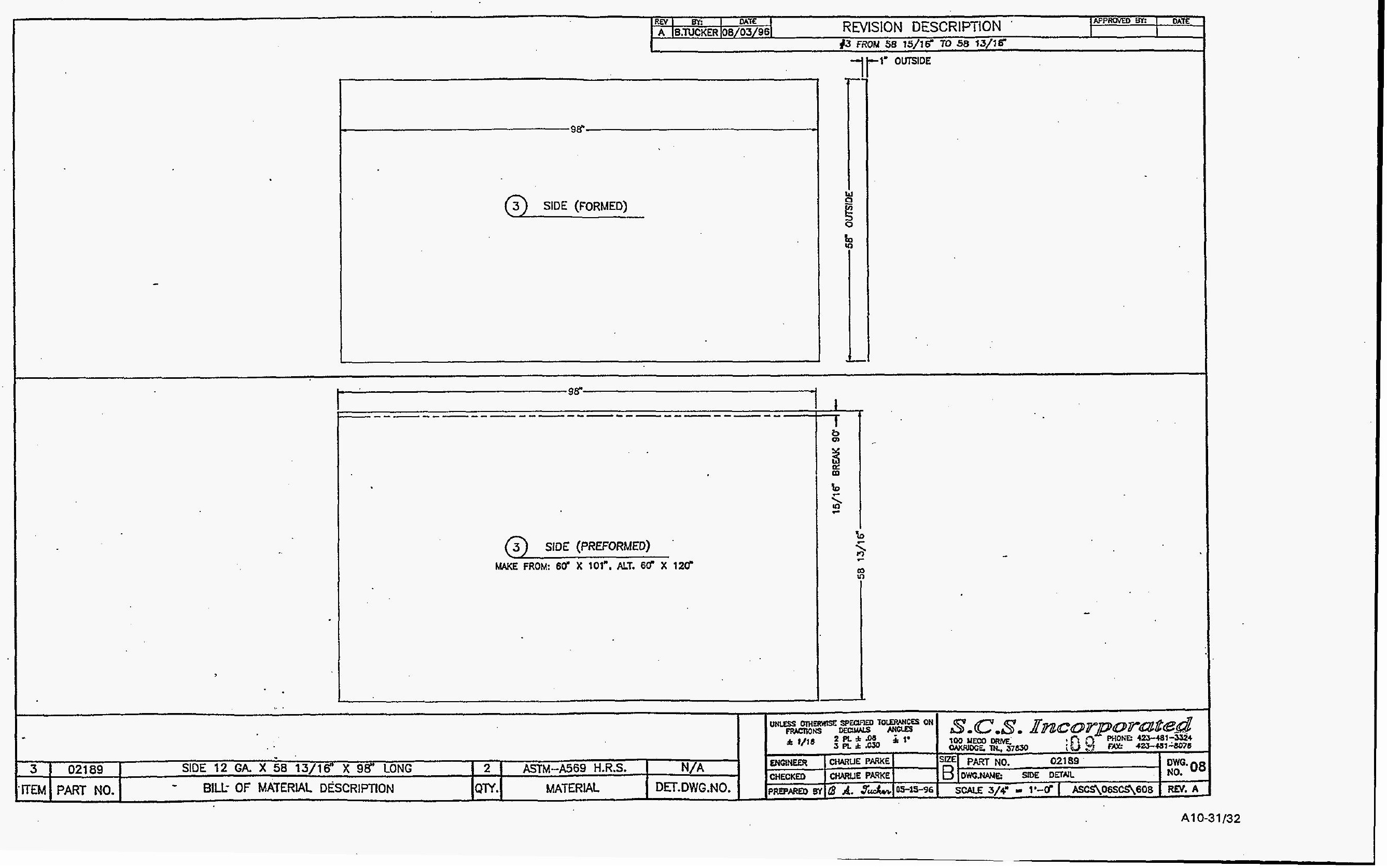




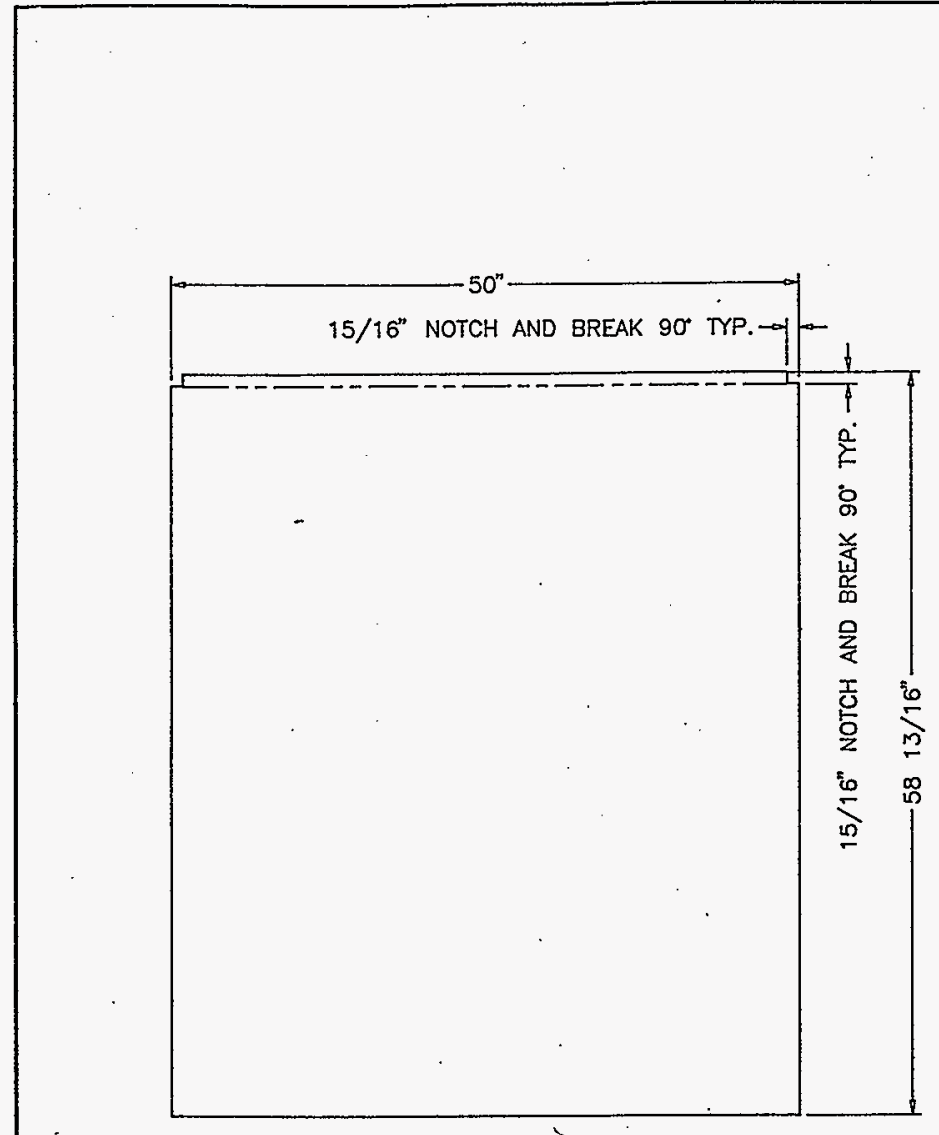

(4) END (PREFORMED)

MAKE FROM: $60^{\prime \prime} \times 51^{\prime \prime}$, ALT. $60^{\circ} \times 96^{\circ}$
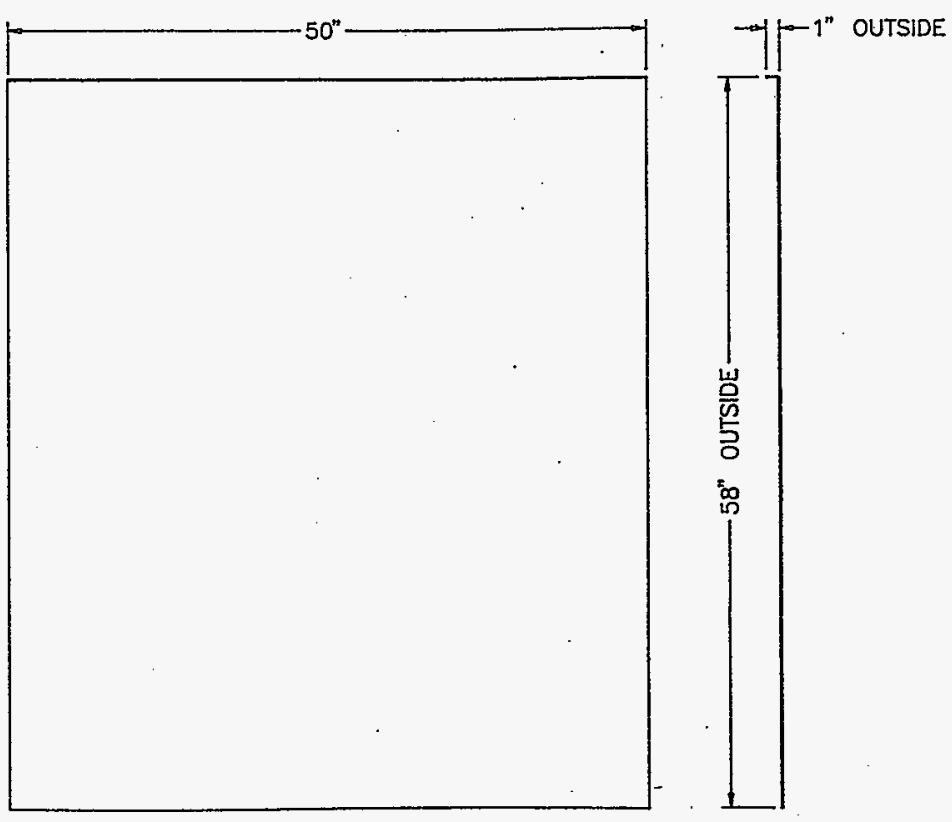

(4) END (FORMED)

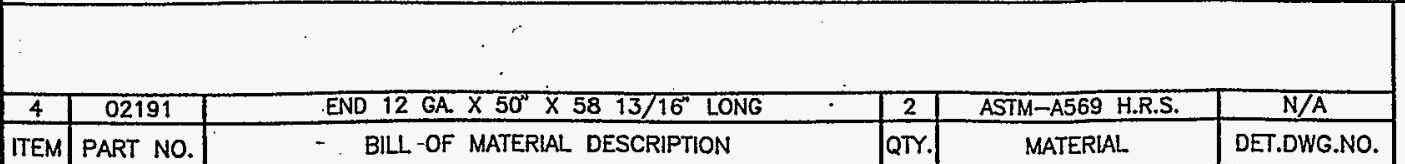

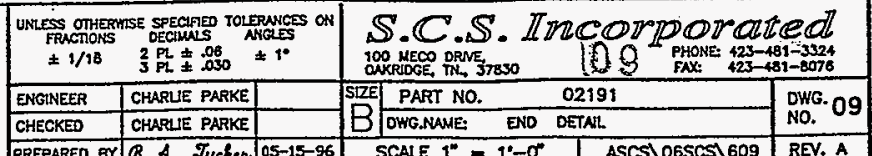




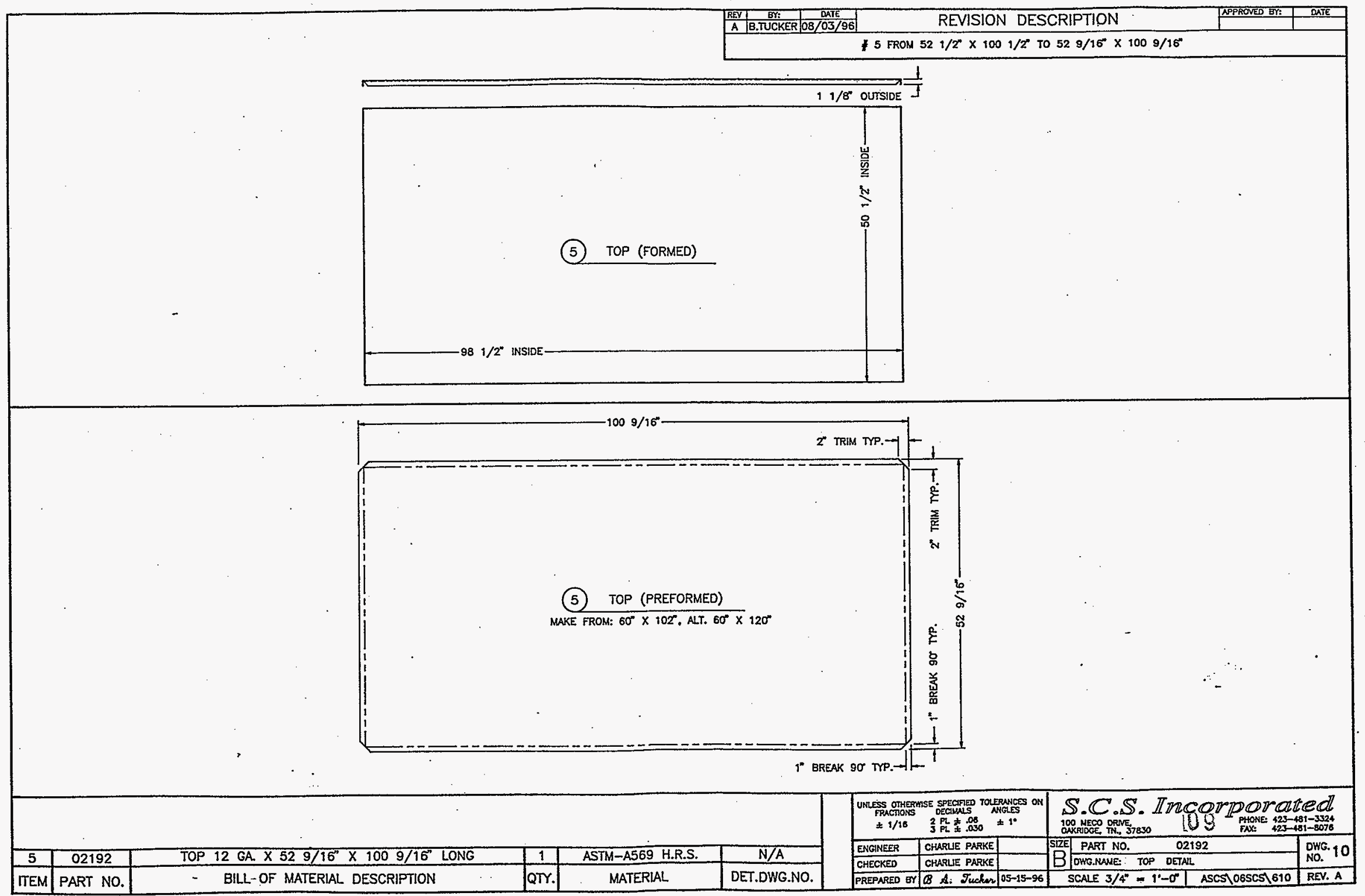

A 10-35/36 


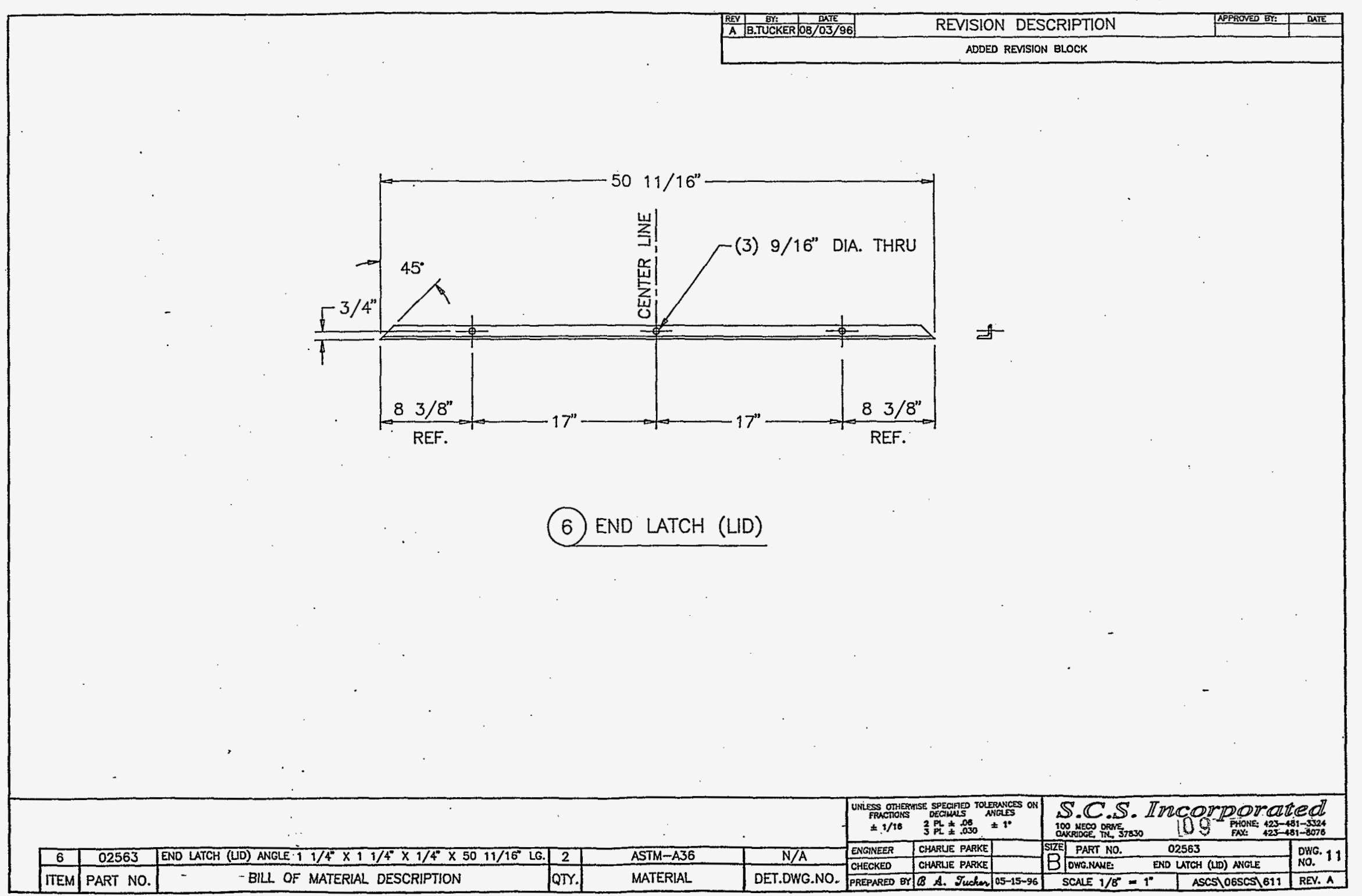

A 10-37/38 


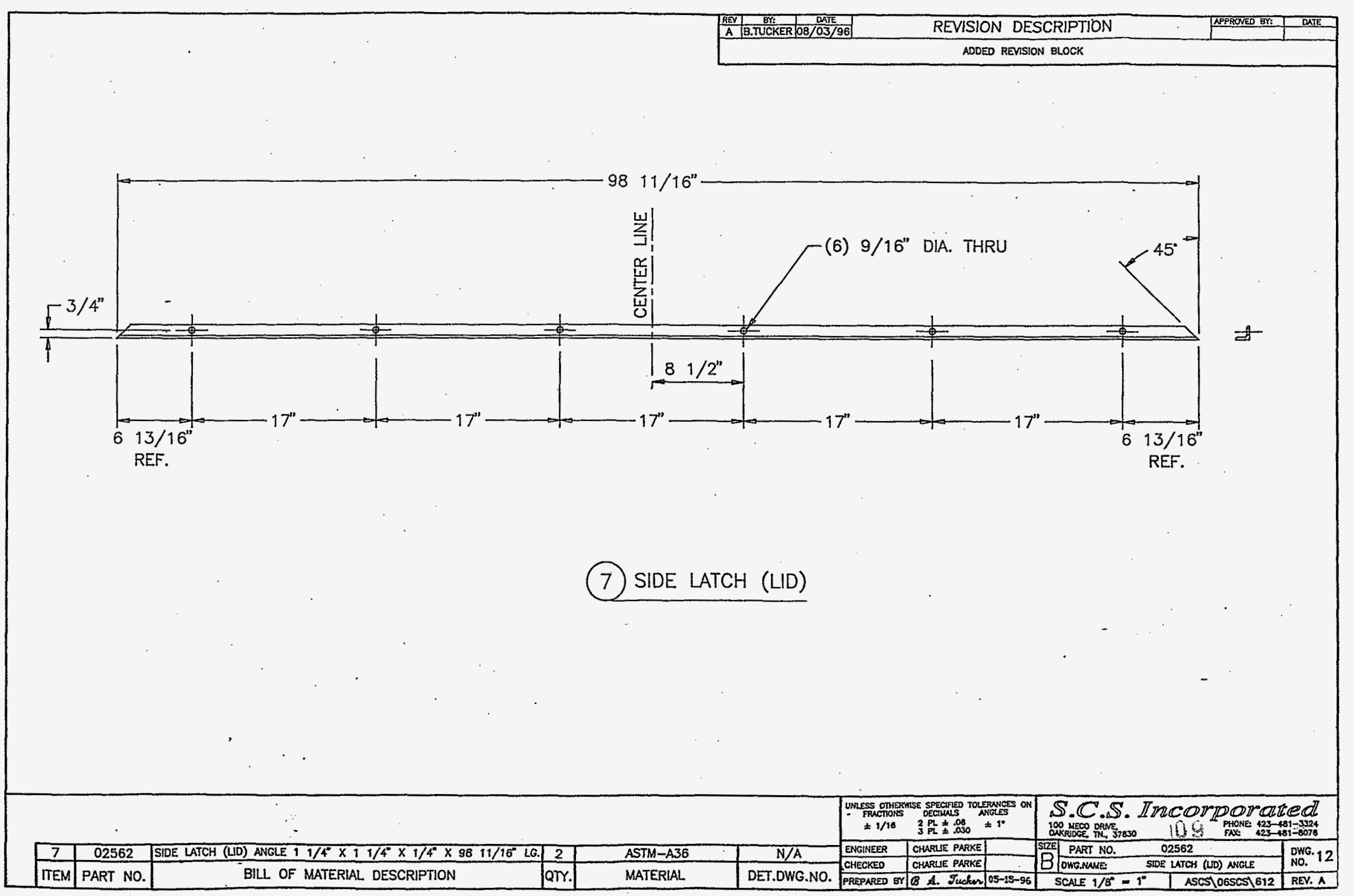


zt/LOLIt

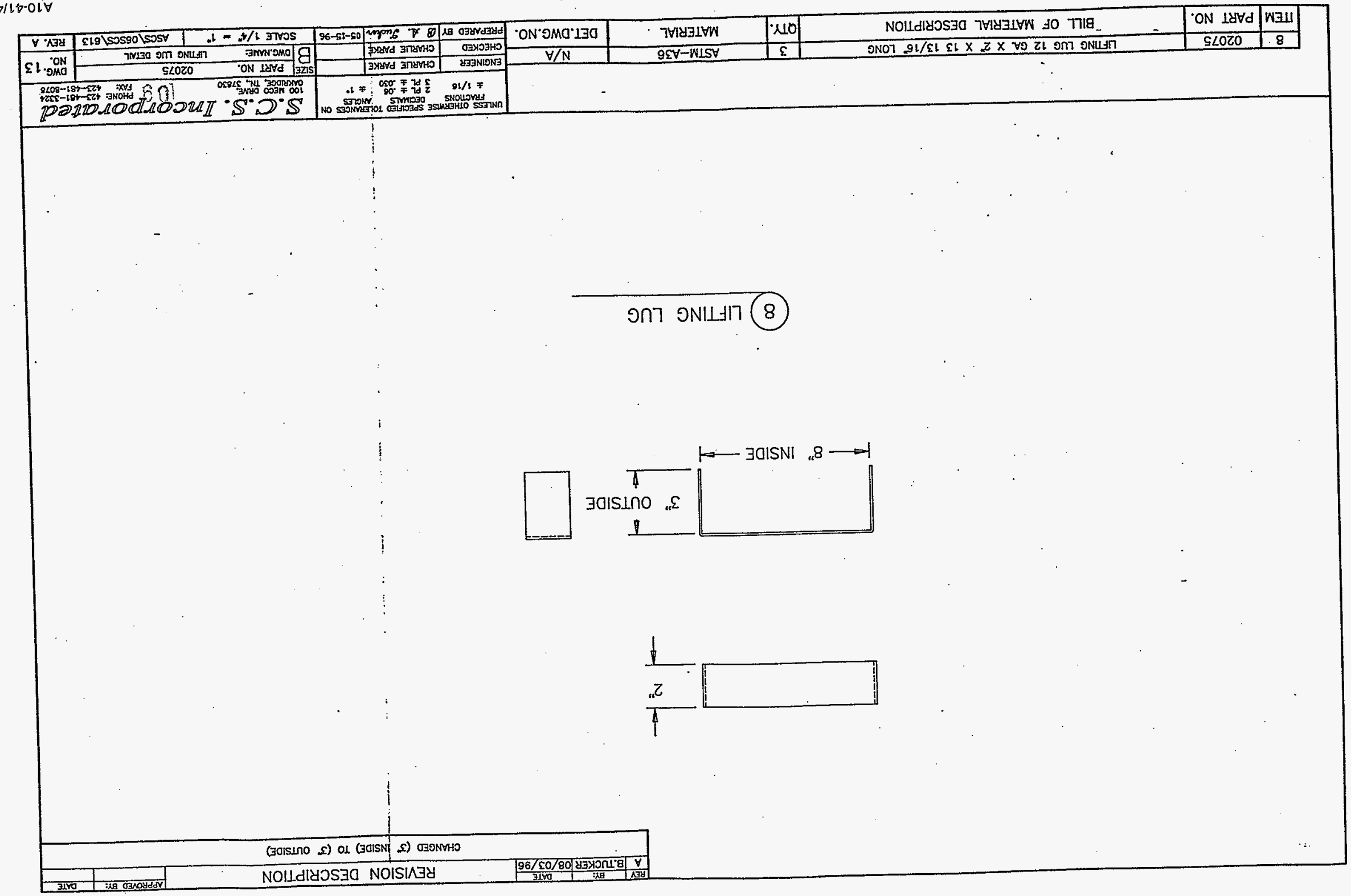




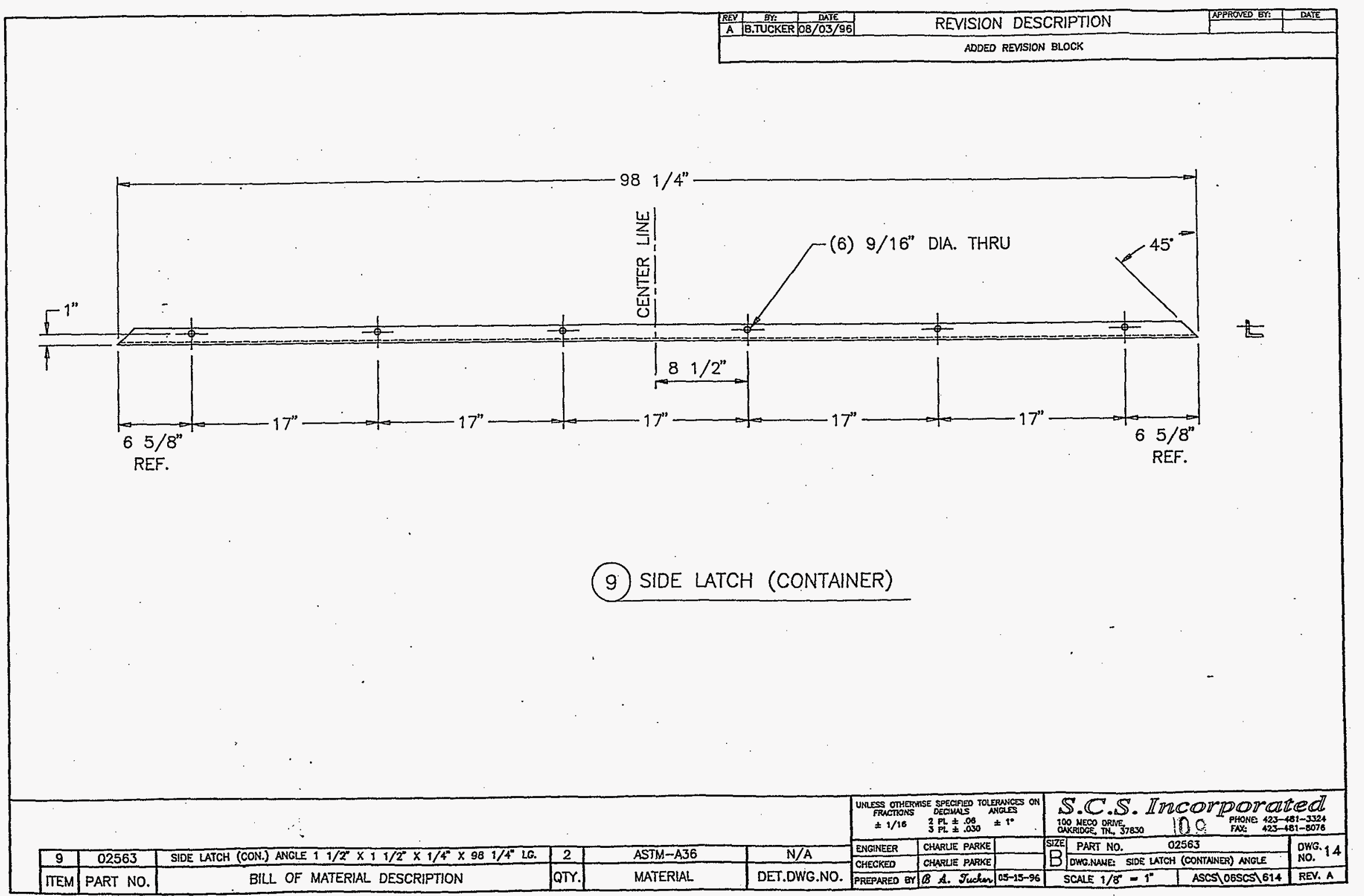




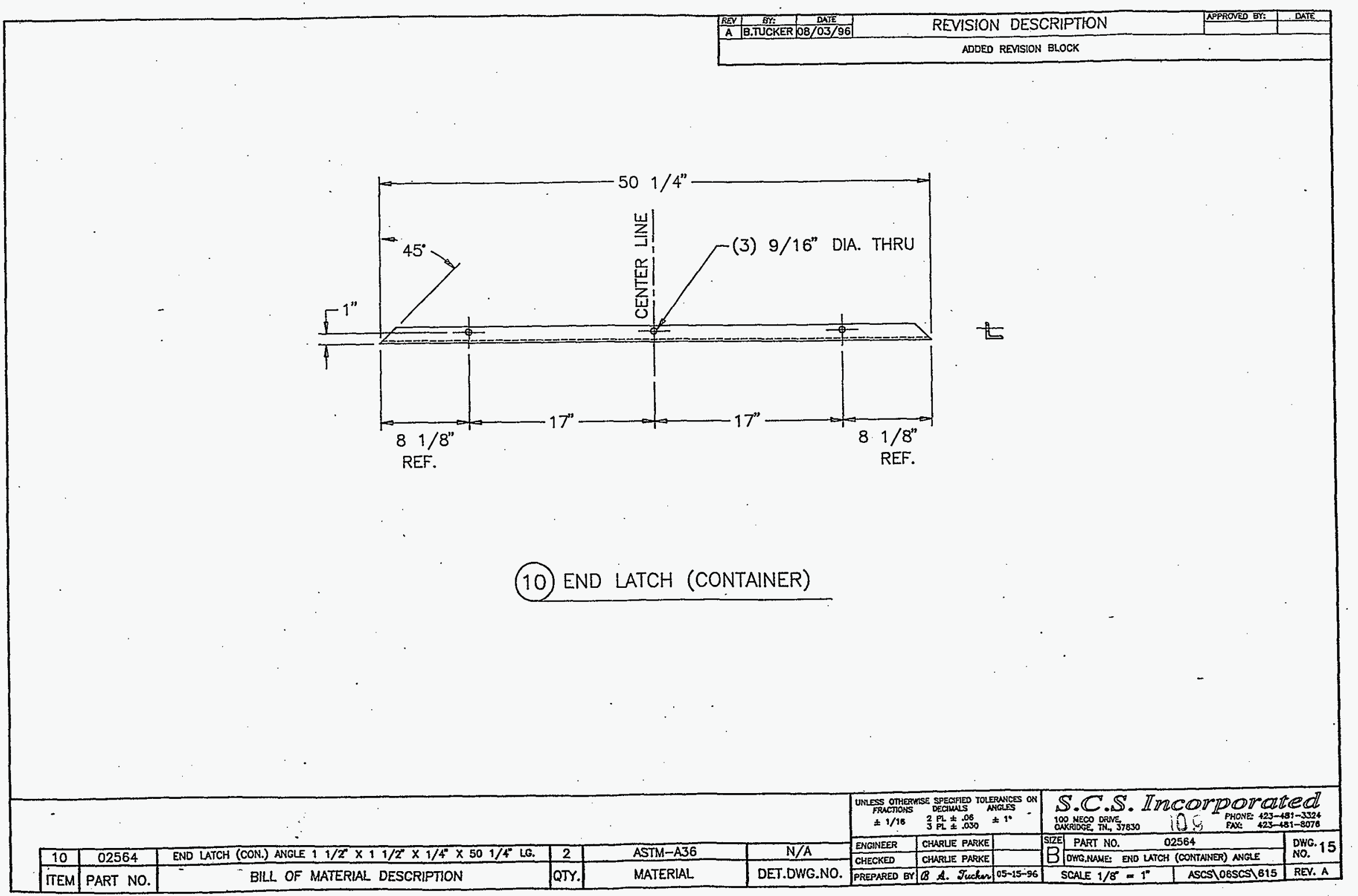




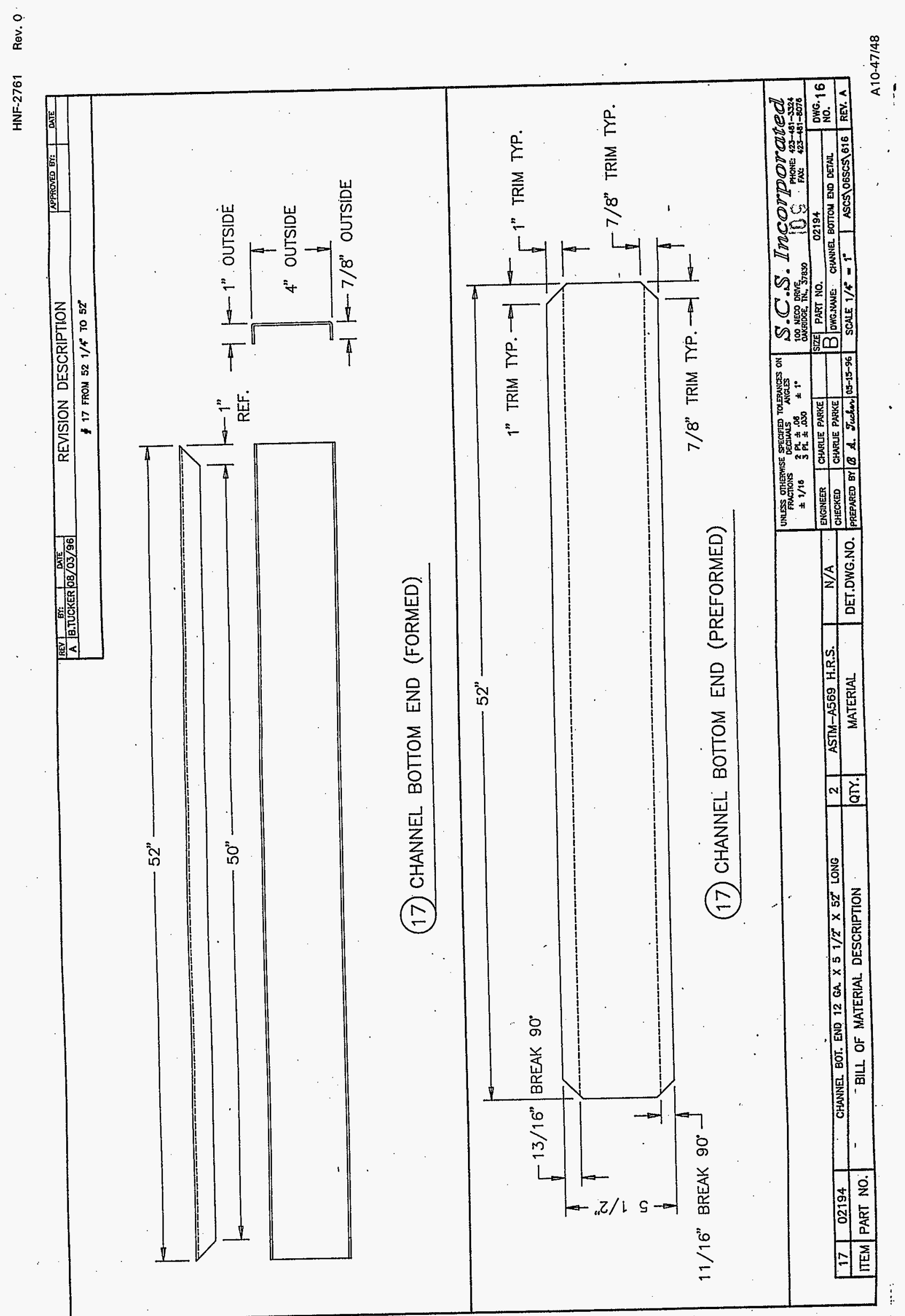




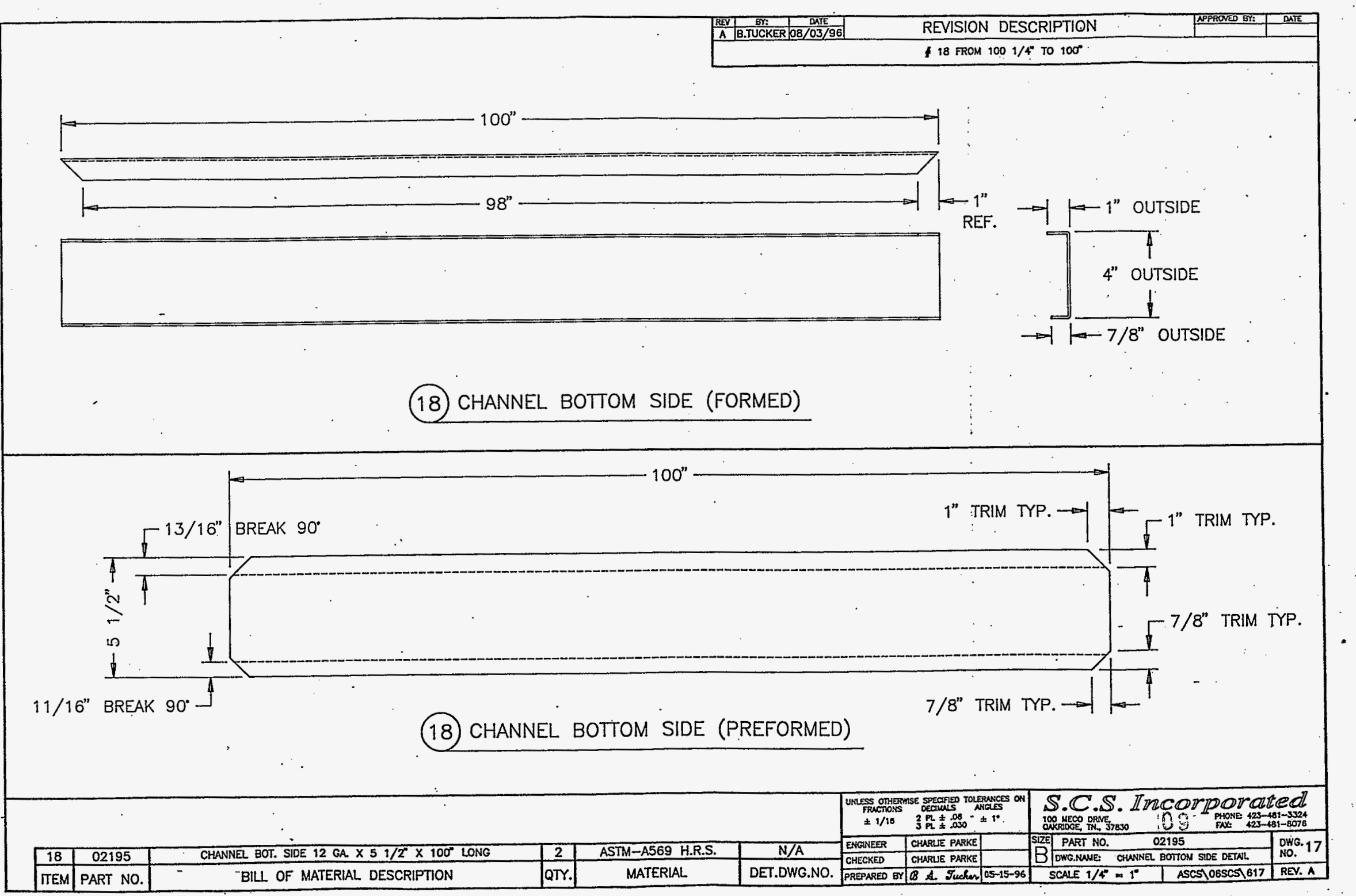


HNF-2761, Rev. 0

PART B: PACKAGE EVALUATION

\subsection{INTRODUCTION}

\subsection{SAFETY EVALUATION METHODOLOGY}

This safety evaluation for packaging (SEP) is for the Pacific Northwest National Laboratory (Pacific Northwest) High-Efficiency Particulate Air (HEPA) Filter Box. The Pacific Northwest HEPA Filter Box will be used for transport of eight HEPA filters from the 325 Building in the 300 Area of the Hanford Site to the Central Waste Complex and on to burial in the 200 West Area. This SEP demonstrates, by analysis or by reference to existing safety analysis reports for packaging, that the Pacific Northwest HEPA Filter Box meets the onsite transportation safety requirements.

\subsection{EVALUATION SUMMARY AND CONCLUSIONS}

The Pacific Northwest HEPA Filter Box meets the established onsite transportation safety requirements for a one-time shipment. This is supported by the results of the dose consequence, risk, shielding, structural, thermal, gas generation, and tiedown analyses of the package.

Since the vehicle which will transport the box is not known, it is left to the user to ensure that the dose rate limits to the driver and at a distance of $1 \mathrm{~m}$ from the package are met. As shown in Part B, Section 5.0, the maximum dose rate measured on the surface of the package was $0.8 \mathrm{mSv} / \mathrm{h}(80 \mathrm{mrem} / \mathrm{h})$. The dose rate limit for the driver is $0.02 \mathrm{mSv} / \mathrm{h}(2 \mathrm{mrem} / \mathrm{h})$ for a nonradiation worker or $0.05 \mathrm{mSv} / \mathrm{h}(5 \mathrm{mrem} / \mathrm{h})$ for a Hanford radiation worker. The dose rate limit at $1 \mathrm{~m}$ from the package is $0.1 \mathrm{mSv} / \mathrm{h}(10 \mathrm{mrem} / \mathrm{h})$. Supplemental shielding may be added to meet the dose rate limits. No additional radioactive material may be added to the payload. 
HNF-2761, Rev. O

This page intentionally left blank.

B1-2 


\subsection{CONTENTS EVALUATION}

\subsection{CHARACTERIZATION}

\subsubsection{Radioactive Source Term}

The radioactive source term was supplied by Pacific Northwest in the form of a radioassay report (see Part A, Section 10.2). This source term is shown in Table $82-1$ below. The radioactive materials present qualify the payload as a nonfissile, Type B, non-highway route controlled quantity.

Table B2-1. HEPA Filter Box Source Term.

\begin{tabular}{|l|l|l|l|l|}
\hline \multirow{2}{*}{ Isotope } & \multicolumn{2}{|c|}{ Activity } & \multirow{2}{*}{$\mathrm{A}_{2}$ (Ci) } & \multirow{2}{*}{ Fraction of $\mathrm{A}_{2}$} \\
\cline { 2 - 3 } & $\mathrm{TBq}$ & $\mathrm{Ci}$ & \\
\hline${ }^{60} \mathrm{Co}$ & $7.36 \mathrm{E}-03$ & $1.99 \mathrm{E}-01$ & $1.08 \mathrm{E}+01$ & $1.84 \mathrm{E}-02$ \\
\hline${ }^{90} \mathrm{Sr}$ & $6.33 \mathrm{E}-01$ & $1.71 \mathrm{E}+01$ & $2.70 \mathrm{E}+00$ & $6.33 \mathrm{E}+00$ \\
\hline${ }^{90} \gamma^{*}$ & $6.33 \mathrm{E}-01$ & $1.71 \mathrm{E}+01$ & $0.00 \mathrm{E}+00$ & $0.00 \mathrm{E}+00$ \\
\hline${ }^{137} \mathrm{Cs}$ & $4.18 \mathrm{E}-01$ & $1.13 \mathrm{E}+01$ & $1.35 \mathrm{E}+01$ & $8.37 \mathrm{E}-01$ \\
\hline${ }^{137 \mathrm{~m} \mathrm{Ba} *}$ & $3.96 \mathrm{E}-01$ & $1.07 \mathrm{E}+01$ & $0.00 \mathrm{E}+00$ & $0.00 \mathrm{E}+00$ \\
\hline${ }^{154} \mathrm{Eu}$ & $1.06 \mathrm{E}-02$ & $2.86 \mathrm{E}-01$ & $1.35 \mathrm{E}+01$ & $2.12 \mathrm{E}-02$ \\
\hline Total & & $5.67 \mathrm{E}+01$ & & $7.21 \mathrm{E}+00$ \\
\hline
\end{tabular}

*Daughter product.

The heat load associated with this source term is $0.17 \mathrm{~W}$.

\subsubsection{Chemical Source Term}

The box and payload consist of inert materials.

\subsection{RESTRICTIONS}

No additional materials may be added to the box.

\subsection{SIZE AND WEIGHT}

The outer box has external dimensions of approximately $255 \mathrm{~cm}$ long $(100.5 \mathrm{in}$.$) by 135 \mathrm{~cm}$ (53.2 in.) wide by $164 \mathrm{~cm}$ (64.5 in.) high. The inner box dimensions are $179 \mathrm{~cm}(70.0 \mathrm{in.}$ ) long by $91.0 \mathrm{~cm}$ ( $36.0 \mathrm{in.}$ ) wide by $140 \mathrm{~cm}$ (55.0 in.) high. The gross weight of the Pacific Northwest HEPA Filter Box is reported to be approximately $4,915 \mathrm{~kg}(10,835 \mathrm{lb})$. The calculated package weight is $4,947 \mathrm{~kg}(10,907 \mathrm{lb}$ ) (see Part $B$, Section 7.0). 
HNF-2761, Rev. 0

\subsection{CONCLUSIONS}

As evaluated by this SEP, the source term to be transported in the Pacific Northwest HEPA Filter Box is a nonfissile, Type B, non-highway route controlled quantity and is acceptable for transportation on the Hanford Site. 
HNF-2761, Rev. 0

\subsection{RADIOLOGICAL RISK EVALUATION}

\subsection{INTRODUCTION}

The Pacific Northwest HEPA Filter Box will transport a Type B quantity of radioactively contaminated HEPA filters from the 300 Area to the 200 Area. Radiological risks are evaluated to determine compliance with onsite transportation safety requirements per HNF-PRO-154, Responsibilities and Procedures for All Hazardous Material Shipments.

The maximum distance of the shipment will be $48.3 \mathrm{~km}$ ( $30 \mathrm{mi}$ ). The assumptions for the radiological risk evaluation are the following:

- Highway mode

- Closed roads when traveling south of the Wye Barricade

- $\quad$ Single shipment

- $\quad 48.3 \mathrm{~km}(30-\mathrm{mi})$ distance.

The box is designed to withstand normal transfer conditions. (NTC). For accident environments, the box must meet onsite transportation safety requirements as outlined in HNF-PRO-154 and Mercado (1994). The requisite safety is determined by a radiological risk evaluation that uses dose consequences, risk acceptance criteria, and Hanford Site accident frequencies. For the evaluation, accidents are categorized as impact, crush, puncture, and fire. Risk acceptance criteria are outlined in Part B, Section 3.2. The dose consequence analyses results are discussed in Part B, Section 3.3. The analysis of accident release frequencies is given in Part $\mathbf{B}$, Section 3.5. The accident frequencies, together with the dose values, provide the necessary input to provide an evaluation of acceptance of the risk related to transporting the box.

\subsubsection{Summary of Results}

Because the capabilities of the box to withstand accident conditions were not analyzed, the total conditional probability of release for mechanical and thermal accident scenarios was assumed to be $100 \%$; i.e., the box is assumed to fail in any accident. The Hanford Site annual accident rate is equal to the annual accident release frequency. The annual release frequency was compared to the dose consequence results to determine acceptance (HNF-PRO-154 and Mercado 1994). For the box, a comparison of the annual release frequency with the criteria determined from the dose consequence study showed the risks to be less than the required maximum of $10^{-6}$ for up to $290 \mathrm{~km}$ (180 mi) per year. Therefore, the transport will comply with onsite transportation safety requirements.

\subsection{RISK ACCEPTANCE CRITERIA}

Graded dose limitations for probable, credible, and incredible accident frequencies ensure safety in radioactive material packaging and transportation (Mercado 1994). The dose limits for the offsite and onsite receptor for probable, credible, and incredible accident frequencies are shown in Table B3-1. 
Table B3-1. Risk Acceptance Criteria Limits (Effective Dose Equivalent).

\begin{tabular}{|l|c|c|c|}
\hline \multicolumn{1}{|c|}{ Description } & Annual frequency & $\begin{array}{c}\text { Onsite dose limit } \\
\text { Sv (rem) }\end{array}$ & $\begin{array}{c}\text { Offsite dose limit } \\
\text { Sv (rem) }\end{array}$ \\
\hline Incredible & $<10^{-7}$ & None & None \\
\hline Incredible & $10^{-7}$ to $<10^{-6}$ & None & $0.25(25)$ \\
\hline Credible & $10^{-6}$ to $10^{-3}$ & $0.05(5)$ & $0.005(0.5)$ \\
\hline Probable & $1 \times 10^{-3}$ to 1 & $0.002(0.2)$ & $0.0001(0.01)$ \\
\hline
\end{tabular}

\subsection{DOSE CONSEQUENCE ANALYSIS RESULTS}

The dose consequence evaluation for the box is discussed in Part B, Section 4.6. The evaluation considers the results of an accident breaching the box and releasing $100 \%$ of the material at risk to the environment. The dose consequence results are shown in Table B3-2 for a ground-level release at the worst location with the worst-case $10.5 \%$ ) meteorology. The dose calculated is the total committed effective dose equivalent, which is integrated over $\mathbf{5 0}$ years.

Table B3-2. Summary of Dose Consequence Results.

\begin{tabular}{|l|c|}
\hline & Offsite receptor Sv (rem) \\
\hline Total effective dose equivalent & $0.0057(0.57)$ \\
\hline
\end{tabular}

Because the dose to the offsite receptor falls in the incredible range, no evaluation of the onsite worker dose was performed.

Because the analysis shows that the dose to the offsite individual is less than $0.25 \mathrm{~Sv}$ $(25 \mathrm{rem})$, the annual accident frequency is limited to $10^{-6}$ to meet the acceptance criteria of Table B3-1.

\subsection{FAILURE THRESHOLD ANALYSIS}

Because the performance capabilities of the box under accident conditions were not evaluated, it is conservatively assumed that the box fails and releases the contents in any accident (impact, puncture, crush, or fire).

\subsection{ACCIDENT FREQUENCY ASSESSMENT}

The accident release frequency assessment is based on the assumption that all failure modes from the different forces described as impact, puncture, crush, and fire result in the same level of consequence. The union of the package conditional release probabilities from different scenarios with similar consequences is multiplied by the frequency of truck accidents to arrive at a total accident release frequency. 
The frequency (F) of a truck accident is the product of the annual number of trips, the number of miles per trip, and the accident rate per mile.

$$
F=\frac{\text { number of trips }}{\text { year }} \times \frac{\text { miles }}{\text { trip }} \times \frac{\text { accidents }}{\text { mile }}
$$

Hanford Site truck accidents have been compiled in a report using Site-specific data (Green et al. 1996), which gives the accident rate for trucks as $2.0 \times 10^{-7}$ accidents per mile. For a shipment of radioactive materials north of the Wye Barricade, which is carried out by trained truck drivers during daylight hours in good road conditions, a total reduction factor of 40 can be applied to lower the rate to $5 \times 10^{-9}$ (H\&R 1995) accidents per mile. Appendix B of Recommended Onsite Transportation Risk Management Methodology (H\&R 1995) summarizes statistics from the U.S. Department of Transportation and the studies conducted by Sandia National Laboratory on accident responses of small and large packages. H\&R (1995) recommends reducing truck accident rates by 10 for "safe" truck drivers, a factor of 2 for travel north of the Wye Barricade, and another factor of 2 for shipment of radioactive material. Travel south of the Wye Barricade will occur only on closed roads, which may reduce accidents by another factor of 20 . However this closed-road reduction factor is conservatively taken to be 2 . The reduction factors are based on the following logic.

- Safe truck drivers: Hanford Site truck drivers have special training. Drivers must complete several driver's education courses, have a valid commercial driver's license with hazardous endorsement, complete specific training for highway route controlled quantities of radioactive material, and complete radiation worker and hazardous materials training. References show that drivers that participate in special safety programs reduce single-vehicle accident rates by up to a factor of 100 . H\&R (1995) recommends using an overall accident reduction factor of 10 .

- Travel north of the Wye Barricade: The general population is excluded north of the Wye Barricade. The roads are straight and generally flat. These conditions eliminate conditions caused by after-work activities, such as alcohol consumption and travel during limited visibility. Statistics show that the difference between travel during day and night leads to an accident reduction of 2.67. Therefore, although the Pacific Northwest HEPA Filter Box is not limited to travel during daylight hours, a conservative factor of 2 reduction is recommended for travel north of the Wye Barricade because there is a constraint on traveling during adverse weather conditions, which may affect visibility, and because no alcohol consumption is permitted on the Hanford Site.

- Travel south of the Wye Barricade: Travel will occur south of the Wye Barricade on closed roads. Road closure reduces rear-end collision by a factor of 10 and multiplevehicle accidents are reduced by another factor of 20 . However, only a reduction factor of 2 is applied in this analysis to be consistent with the approach to the portion of the shipment north of the Wye Barricade .

- Radioactive material: An additional factor of 2 is recommended based on the higher level of training required for drivers of vehicles carrying radioactive material and the higher level of caution that would be expected from drivers of cargos consisting of radioactive material.

The calculated accident frequency is multiplied by the conditional release probability to arrive at an annual accident release frequency. The annual release frequency is compared to the criteria determined from the dose consequence analysis $\left(<10^{-6}\right)$. 
The conditional probability of release, given an accident, is conservatively assumed to be 1.0 for the box; that is, the box is assumed to fail in any accident.

\subsection{EVALUATION AND CONCLUSION}

The conditional release probability (1.0) is multiplied by $F\left(1.5 \times 10^{-7}\right.$ accidents/year $)$, the frequency, to arrive at an annual accident release frequency. The annual accident release frequency is less than the $10^{6}$ criterion; therefore, the transport of the box is shown to meet transportation safety requirements.

\subsection{REFERENCES}

Dennis, A. W., J. T. Foley, W. F. Hartman, and D. W. Larson, 1978, Severities of Transportation Accidents Involving Large Packages, SAND77-0001, Sandia National Laboratories, Albuquerque, New Mexico.

Green, J. R., B. D. Flanagan, and H. Harris, 1996, Hanford Site Truck Accident Rate, 1990-1995, WHC-SD-TP-RPT-021, Rev. 0, Westinghouse Hanford Company, Richland, Washington.

H\&R, 1995, Recommended Onsite Transportation Risk Management Methodology, 522-1, H\&R Technical Associates, Inc., Oak Ridge, Tennessee.

HNF-PRO-154 Responsibilities and Procedures for All Hazardous Material Shipments, Fluor Daniel Hanford, Inc., Richland, Washington.

Mercado, J. E., 1994, Report on Equivalent Safety for Transportation and Packaging of Radioactive Materials, WHC-SD-TP-RPT-001, Rev. O, Westinghouse Hanford Company, Richland, Washington. 


\subsection{CONTAINMENT EVALUATION}

\subsection{INTRODUCTION}

The Pacific Northwest HEPA Filter Box contents consist of eight HEPA filters removed from Building 325 in the Hanford 300 Area. Four of the filters contain radioactive materials entrained in the filter medium. These four filters are contained in an inner steel box with a bolted lid. This box provides shielding and confinement of the contents within its boundary. The other four fiiters contain no radioactive material, but cannot be free released, so are packed between the inner and outer boxes. The outer box is sealed with a gasketed lid as shown in the manufacturer's drawings in Part A, Section 10.3.

\subsection{CONTAINMENT SOURCE SPECIFICATION}

As described in Part B, Section 2.0.

\subsection{NORMAL TRANSFER CONDITIONS}

\subsubsection{Conditions To Be Evaluated}

The NTC tests evaluated or addressed are only the forces due to normal transportation. Note that this box was not evaluated for and will most likely not withstand a significant drop and will not meet the conditions of an IP-2 or 7A package (49 CFR 173). Therefore, no transloading of the box is authorized during transfer outside the Hanford Central Waste Complex, burial grounds, or the 300 Area. Accidents within these boundaries are within the purview of the facility safety analysis reports.

\subsubsection{Containment Acceptance Criteria}

There shall be no leakage of waste material from the container under normal conditions.

\subsubsection{Containment Calculations}

As demonstrated in Part B, Section 7.0, the waste will be confined within the inner steel box through the NTC evaluated. The stresses are shown not to exceed Boiler and Pressure Vessel Code (B\&PVC), Section II, Subsection D (ASME 1992), allowables for the materials involved. Analysis is provided in Part B, Section 7.0.

\subsection{ACCIDENT CONDITIONS}

Accident conditions that result in excessive loading on the inner cavity flange or bolting could result in breach of containment.

Should an accident occur in which these loadings are exceeded, the dose consequences of such an accident are found to be acceptable, as described in Part B, Section 4.6. 


\subsection{CONTAINMENT EVALUATION AND CONCLUSIONS}

The Pacific Northwest HEPA Filter Box will prevent any loss or dispersal of the radioactive contents when exposed to the NTC.

\subsection{DOSE CONSEQUENCE ANALYSIS (OF ACCIDENTS)}

\subsubsection{Introduction}

This section documents the dose consequence calculations used to support the Transportation Hazard Indicator (THI) evaluation and the radiological risk evaluation for the box.

Because the public receptor dose is greater than 0.5 rem and the dose to the onsite worker is assumed to be greater than 5 rem, the packaging must be designed to THI 2 requirements. The criteria for a THI of 2, as stated in HNF-PRO-154, is:

THI-2: This represents the second highest level of hazard from the contents. A packaging system assigned this level transports material that has the potential of causing a dose consequence, to an individual between $0.5 \mathrm{rem}$ and $25 \mathrm{rem}$ at the Hanford Site boundary, or greater than 5 rem within the site, if fully released.

Table B4-1 shows the dose corresponding to an accident event involving the box. The dose consequences of a nonthermal event bound those for a thermal event.

Table B4-1. Summary of Doses for Maximum Public Receptor for an Accident (Nonthermal) Event Involving the Box.

\begin{tabular}{|l|c|c|}
\hline \multicolumn{1}{|c|}{ Exposure pathway } & Sv & Rem \\
\hline External photon dose & NA & NA \\
\hline External dose from beta particles & NA & NA \\
\hline Inhalation and submersion airborne transport pathway & 0.0057 & 0.57 \\
\hline $\begin{array}{l}\text { Skin contamination and ingestion from handling package } \\
\text { contents }\end{array}$ & NA & NA \\
\hline Submersion dose from gaseous vapor & NA & NA \\
\hline Total effective dose equivalent & 0.0057 & 0.57 \\
\hline
\end{tabular}
300 Area.

Note: The maximum public receptor dose is located $100 \mathrm{~m}$ north of the release point in the

\subsubsection{Methodology}

The International Atomic Energy Agency (IAEA) Safety Series No. 7 (IAEA 1990) defines a standardized approach for evaluating transportation packaging requirements, called the $\mathrm{Q}$-system.

In the Q-system, the following five exposure pathways are considered: (1) external exposure to photons, (2) external exposure to beta particles, (3) inhalation, (4) skin contamination and ingestion, and (5) submersion in a cloud of gaseous isotopes. In special cases, such as alpha particle or neutron emitters, other exposure routes are considered. In some cases a pathway is 
judged to be small with respect to the others, and consideration is minimal. Modifications to the IAEA scenarios are incorporated to more accurately model the particular conditions of the onsite shipment. Detailed calculations for the postulated accident are performed whenever possible. However, in some cases, the IAEA guide's (IAEA 1990) worst-case rules-of-thumb are applied.

The Q-system was developed as an all-encompassing generalized methodology using only the isotope as the defining variable. In this evaluation, the specifics of the payload are considered, and although all these pathways are covered in IAEA (1990), some are disregarded in the analysis.

In this IAEA system, the Q-values that are calculated are the radionuclide activities corresponding to each exposure route that causes the individual to receive the effective dose equivalent limit. The minimum $Q$-values define the $A_{2}$ values for the isotope of interest. In the case of nondispersible materials (limited by the $A_{1}$ values), only the first two Q-values (based on exposure to external photon and external beta particles) are applicable. Note that for all radiation except neutrons, protons, and heavier charged particles (including alpha particles), $1 \mathrm{~Gy}=1 \mathrm{~Sv}$, and $1 \mathrm{rad}=1 \mathrm{rem}$.

There are two receptors of interest in the Q-system. They are the Hanford Site worker and the offsite receptor. The Hanford Site worker is assumed to be located at or near the package and, thus, the point of release. The offsite receptor is assumed to be located at the boundary of the Hanford Site. For the offsite receptor, inhalation, ingestion, and direct exposure from submersion in a cloud are considered.

The analysis is based on the source term for the box listed in Table B2-1. Part B, Section 4.6.3, addresses the source term, and Part B, Sections 4.6.4 through 4.6.9, discuss the dose consequence calculations.

\subsubsection{Source Term}

Part B, Section 2.0, discusses the source term for the box.

\subsubsection{External Dose Due to Photon (Gamma) Exposure}

The IAEA scenario assumes that a person is exposed to a damaged transport package following an accident. The shielding of the package is assumed to be completely lost in the accident. This exposure pathway does not apply to the offsite receptor because the minimum distance from the box to the receptor is $100 \mathrm{~m}$.

\subsubsection{External Dose Due to Beta Particle Emitters}

Because of the limited range of beta particles relative to that of photons, a shielding factor is used by the IAEA to account for residual shielding from such material as package debris. As discussed in Part B, Section 4.6.4, the external dose pathway is not applicable to the offsite receptor.

\subsubsection{Inhalation and Ingestion Dose}

Radioactive material may be inhaled following an accident due to resuspension or volatilization of the material released from the package. This section addresses dose consequences from a postulated accident event that affects the contents of the well car and results in an airborne 
release of radioactive material. The nonthermal event results bound those for a thermal event; therefore, only the former is evaluated.

\subsubsection{HEPA Filter Box Accident Release Quantity. Airborne Re/ease Fractions/Rates and} Respirable Fractions for Nonreactor Nuclear Facilities (DOE 1994) provides specific guidance for an ARF $\times$ RF for unenclosed contaminated HEPA filters. The bounding value for the ARF and RF are applied. For this analysis, it is conservatively assumed that $1 \%$ of the waste material is made airborne. It is further assumed that $100 \%$ of this material is in the respirable range; i.e., made available for being transported and inhaled by a downwind receptor. This assumption results in an ARF $\times R F$ of 0.01 . This ARF $\times R F$ is applied to the material at risk, which is conservatively assumed to be the entire contents of the box, to obtain the quantity of radioactive material that is made airborne during the postulated accident scenario.

Table B4-2 lists the accident release quantities, which were calculated using the radionuclide inventories from Table B2-1 and applying the ARF $\times$ RF value of $1 \times 10^{-2}$ to all radionuclides.

Table B4-2. Accident Release Quantities.

\begin{tabular}{|l|c|c|}
\hline \multirow{2}{*}{ Radionuclide } & \multicolumn{2}{|c|}{ Activity } \\
\cline { 2 - 3 } & $\mathrm{Bq}$ & $\mathrm{Ci}$ \\
\hline${ }^{60} \mathrm{Co}$ & $7.36 \mathrm{E}+07$ & $1.99 \mathrm{E}-03$ \\
\hline${ }^{90} \mathrm{Sr}$ & $6.33 \mathrm{E}+09$ & $1.71 \mathrm{E}-01$ \\
\hline${ }^{90} \mathrm{Y}$ & $6.33 \mathrm{E}+09$ & $1.71 \mathrm{E}-01$ \\
\hline${ }^{137} \mathrm{Cs}$ & $4.18 \mathrm{E}+09$ & $1.13 \mathrm{E}-01$ \\
\hline${ }^{137 m} \mathrm{Ba}$ & $3.96 \mathrm{E}+09$ & $1.07 \mathrm{E}-01$ \\
\hline${ }^{154} \mathrm{Eu}$ & $1.06 \mathrm{E}+08$ & $2.86 \mathrm{E}-03$ \\
\hline Totals & $2.10 \mathrm{E}+10$ & $5.67 \mathrm{E}-01$ \\
\hline
\end{tabular}

4.6.6.2 Discussion of Integrated Normalized Air Concentration Value ( $\left.x / \mathrm{Q}^{\prime}\right)$. In the dose consequence evaluation model it is assumed that after the radioactive material becomes airborne, it is transported downwind and inhaled by onsite workers or the public. The concentration of this material is reduced, or diluted, as it is being transported due to atmospheric mixing and turbulence. $\mathrm{X} / \mathrm{Q}^{\prime}\left(\mathrm{s} / \mathrm{m}^{3}\right)$ is used to characterize the dilution of the airborne contaminants during atmospheric transport and dispersion. It is equal to the time-integrated normalized air concentration at the receptor. $X / Q^{\prime}$ is a function of the atmospheric conditions (i.e., wind speed, stability class) and the distance to the receptor.

Bounding $X / Q^{\prime}$ values are generated consistent with the methods described in the U.S. Nuclear Regulatory Commission (NRC) Regulatory Guide 1.145, Atmospheric Dispersion Models for Potential Accident Consequence Assessments at Nuclear Power Plants (NRC 1982). Because atmospheric conditions fluctuate, a bounding atmospheric condition is determined to be that condition that causes a downwind exposure of airborne contaminants that is exceeded only a small fraction of time because of weather fluctuations. NRC (1982) defines this fraction of exceedance as $0.5 \%$ for each sector or $5 \%$ for the overall Hanford Site. The Hanford Site is broken up into 16 sectors that represent 16 compass directions (i.e., S, SSW, SW, .., ESE, SE, $S S E) . X / Q^{\prime}$ values are generated for weather conditions that result in downwind exposures exceeded only $0.5 \%$ of the time in the maximum sector or $5 \%$ of the time for the overall Site. 
These $X / Q^{\prime}$ values are also referred to as $99.5 \%$ maximum sector and $95 \%$ overall Site $X / Q^{\prime}$ values. The greater of these two values is called the bounding $X / 0^{\prime}$ value and is used to assess the dose consequences for accident scenarios. The bounding $X / Q^{\prime}$ value represents minimum dispersing conditions that result in maximum downwind exposures; i.e., exposures exceeded.only a very small fraction of the time. This $X / O^{\prime}$ value will therefore result in very conservative estimates of accident consequences.

The $X / Q^{\prime}$ value in this evaluation was generated using the $\mathrm{GXO}$ computer code, Version 4 (Hey 1995a, Hey 1995b). The meteorological data used by GXO are in the form of joint frequency tables. The joint frequency data are the most recent data available; they are 9-year-averaged data (1983-1991) from the Hanford Site meteorology towers. As mentioned above, the $X / Q^{\prime}$ values are generated using the methods described in NRC (1982) for a ground release with no credit taken for plume rise, plume meander, plume depletion, or any other models. This approach is conservative because all these models reduce the airborne concentration at the downwind receptor locations.

The worst-case public receptor (i.e., highest $X / 0^{\prime}$ ) will be located in the 300 Area due to the short distances between the transport routes and a public receptor. The maximum offsite receptor $\mathrm{X} / \mathrm{O}^{\prime}$ value is $4.21 \times 10^{-2} \mathrm{~s} / \mathrm{m}^{3}$, corresponding to a position $100 \mathrm{~m}$ north of the release point.

The GXO input file is listed in Part B, Section 4.8.1, and the titles of the joint frequency files are listed below.

200 AREA (HMS) - $10 \mathrm{M}$ - Pasquill A - G (1983 - 1991 Average)

300 AREA - $10 \mathrm{M}$ - Pasquill A - G (1983 - 1991 Average)

4.6.6.3 Inhalation and Submersion Dose Calculations. Because the GENII computer code Version 1.485 (Napier et al. 1988) is the Site standard computer code for environmental release dose calculations, it was used to calculate the inhalation and submersion dose for the maximum onsite receptor and public receptors. The airborne release quantities used in GENII are listed in Table B4-2. The GENII input deck is listed in Part B, Section 4.8.2. The worst-case solubility class library was used. The GENIl libraries used were as follows:

GENII Default Parameter Values (28-Mar-90 RAP)

Radionuclide Library - Times $<100$ years $(23-J u l y-93$ PDR $)$

External Dose Factors for GENII in person Sv/yr per Bq/n (8-May-90)

Worst-Case Solubilities, Yearly Dose Increments (23-Jul-93 PDR)

The effective-dose equivalent (EDE) from GENII for the inhalation and submersion pathways is $0.0057 \mathrm{~Sv}(0.57 \mathrm{rem})$ for the maximum offsite receptor located $100 \mathrm{~m}$ from the release point in the 300 Area. The inhalation dose contribution to the EDE is based on a 50-year dose commitment period.

4.6.6.4 Ingestion Dose for Offsite Receptor. The other potential internal exposure pathway for the offsite receptor is the ingestion pathway. Exposure through the ingestion pathway occurs when radioactive materials that have been deposited offsite during passage of the plume are ingested either by eating crops grown in, or animals raised on, contaminated soil or through drinking contaminated water. There are U.S. Department of Energy; U.S. Department of Energy, Richland Operations Office; state; and federal programs in place to prevent ingestion of contaminated food in the event of an accident (RL 1994, WSDOH 1993, WSDA 1994, EPA 1992). The primary determinant of exposure from the ingestion pathway is the effectiveness of public health measures (i.e., interdiction) rather than the severity of the accident itself. The ingestion pathway, if it occurs, is a slow-to-develop pathway and is not considered an immediate threat to an exposed population in the same sense as airborne plume exposures. 
The ground shine pathway is an additional potential external exposure pathway for the offsite receptor. Ground shine refers to the external dose received by a person standing on ground contaminated by radioactive materials deposited during passage of the airborne radioactive plume. Similar to the ingestion pathway, the primary determinant of exposure from the ground shine pathway is the effectiveness of public health measures (i.e., interdiction) rather than the severity of the accident itself. The ground shine pathway is a slow-to-develop pathway and is not considered an immediate threat to an exposed population in the same sense as airborne plume exposures.

It is argued that in the event of an accident scenario that results in the release of this inventory, interdictive measures (RL 1994, WSDOH 1993, WSDA 1994, EPA 1992) would be taken to prevent ingestion of contaminated food and exposure through the ground shine pathway. Therefore, the ingestion and ground shine pathway doses were not calculated in this evaluation.

\subsubsection{Dose Due to Beta-Particle Emitter Skin Contamination}

In IAEA (1990), it is assumed that $1 \%$ of the package contents are spread over an area of $1 \mathrm{~m}^{2}$ and that handling of debris results in contamination of the hands to $10 \%$ of this level. It is further assumed that the worker is not wearing gloves, but that he recognizes the possibility of contamination and washes his hands within 5 hours. The EDE to the skin received by the individual is estimated from a graph provided in IAEA (1990).

The IAEA scenario for the uptake of activity due to ingestion of the material assumes that the person ingests all of the contamination from $10 \mathrm{~cm}^{2}$ of skin over a 24-hour period. Since the dose per unit uptake via inhalation is generally the same order or larger than that via ingestion, the inhalation pathway will normally be limiting for internal contamination due to beta-ray emitters. In particular, if the skin contamination dose is much larger than the inhalation dose, the ingestion pathway is not considered.

Both these pathways are ordinarily neglected when calculating the dose consequences from an onsite transportation accident. The transportation workers are trained in the appropriate response to protect themselves from experiencing unnecessary radiation exposure, including preventing skin contamination and ingestion.

\subsubsection{Submersion Dose Due to Gaseous Vapor}

This exposure pathway is caused by submersion in a cloud of gaseous isotopes that is not taken into the body. A rapid release of $100 \%$ of the package contents is assumed. (AEA (1990) concentrates entirely on releases within confined structures. No guidance is given for outside releases.

There are no gaseous isotopes present in the HEPA filters; therefore, this exposure pathway is not applicable.

\subsubsection{Special Considerations}

Alpha particle emitters are not of significance in the material considered in this evaluation. Alpha particle emitters are not present in the HEPA filters.

Bremsstrahlung has been included in the consideration of photon effects, and the effects of short-lived daughter products have been included in all of the calculations. Where these isotopes are significant, they are assumed to be in equilibrium with their longer-lived parent isotopes. 
HNF-2761, Rev. 0

\subsection{REFERENCES}

49 CFR 173, "Shippers--General Requirements for Shipments and Packagings," Code of Federal Regulations, as amended.

ASME, 1992, Boiler and Pressure Vessel Code, Section II, Subsection D, American Society of Mechanical Engineers, New York, New York.

DOE, 1994, Airborne Release Fractions/Rates and Respirable Fractions for Nonreactor Nuclear Facilities, DOE-HDBK-3010-94, U.S. Department of Energy, Washington, D.C.

EPA, 1992, Manual of Protective Action Guides and Protective Actions for Nuclear Incidents, U.S. Environmental Protection Agency, Washington, D.C.

Hey, B. E., 1995a, GXO 4.0 Program User's Guide, WHC-SD-GN-SWD-30002, Rev. 1, Westinghouse Hanford Company, Richland, Washington.

Hey, B. E., 1995b, GXQ 4.0 Program Verification and Validation, WHC-SD-GN-SWD-30003, Rev. 1, Westinghouse Hanford Company, Richland, Washington.

HNF-PRO-154, Responsibilities and Procedures for All Hazardous Material Shipments, Fluor Daniel Hanford, Inc., Richland, Washington.

IAEA, 1990, Explanatory Material for the IAEA Regulations for the Safe Transport of Radioactive Material, IAEA Safety Series No. 7, Second Edition (As Amended in 1990), International Atomic Energy Agency, Vienna, Austria.

Napier, B. A., et al., 1988, GENII - The Hanford Environmental Radiation Dosimetry Software System, PNL-6584, Volume 1, UC-600, Pacific Northwest Laboratory, Richland, Washington.

NRC, 1982, Atmospheric Dispersion Models for Potential Accident Consequence Assessments at Nuclear Power Plants, Regulatory Guide 1.145, U.S. Nuclear Regulatory Commission, Washington, D.C.

RL, 1994, Emergency Implementation Procedures, DOE-0223, U.S. Department of Energy, Richland Operations Office, Richland, Washington.

WSDA, 1994, Fixed Nuclear Facility Emergency Response Procedure, Section 10.6, Washington State Department of Agriculture, Olympia, Washington.

WSDOH, 1993, "Response Procedures for Radiation Emergencies," Protective Action Guides, Appendix A, Washington State Department of Health, Olympia, Washington. 


\subsection{APPENDICES}

\subsubsection{GXO Input File}

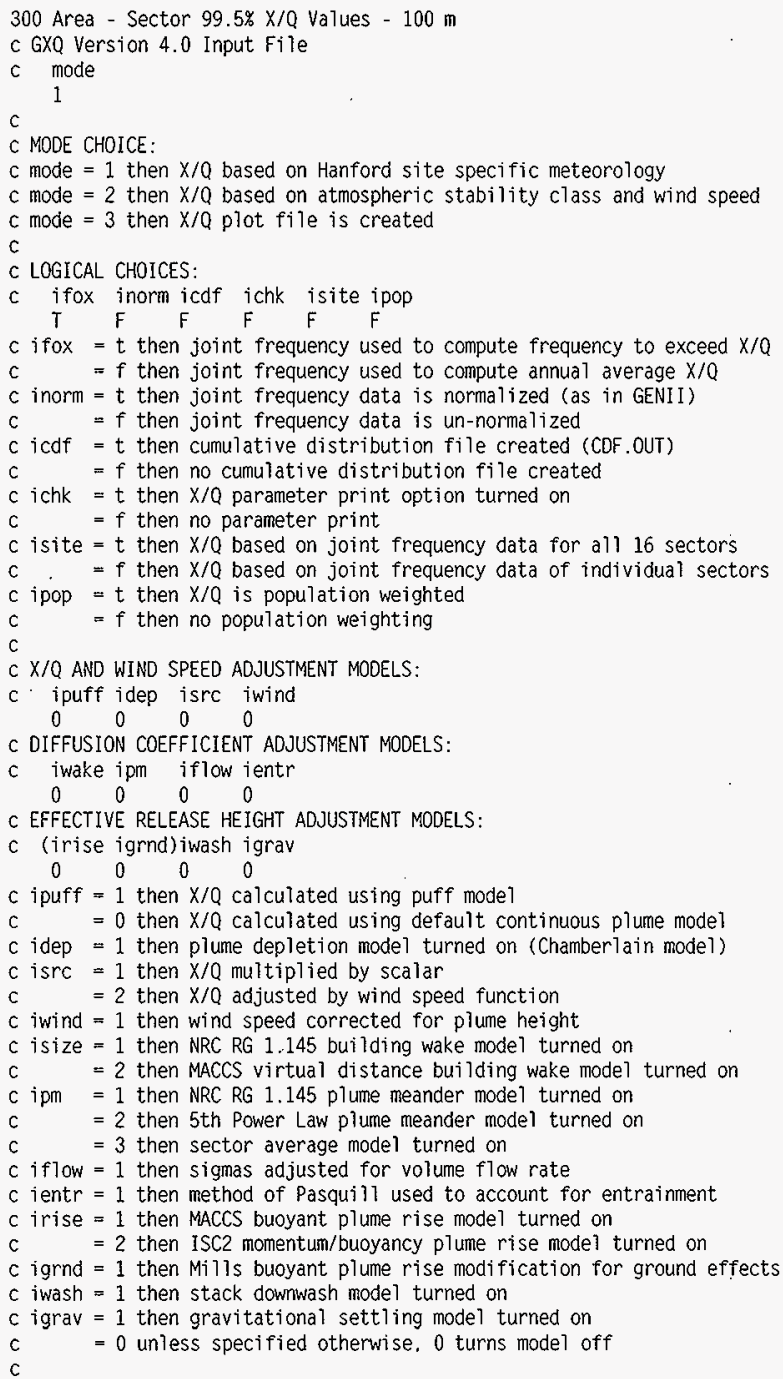


HNF-2761, Rev. O

c PARAMETER INPUT:

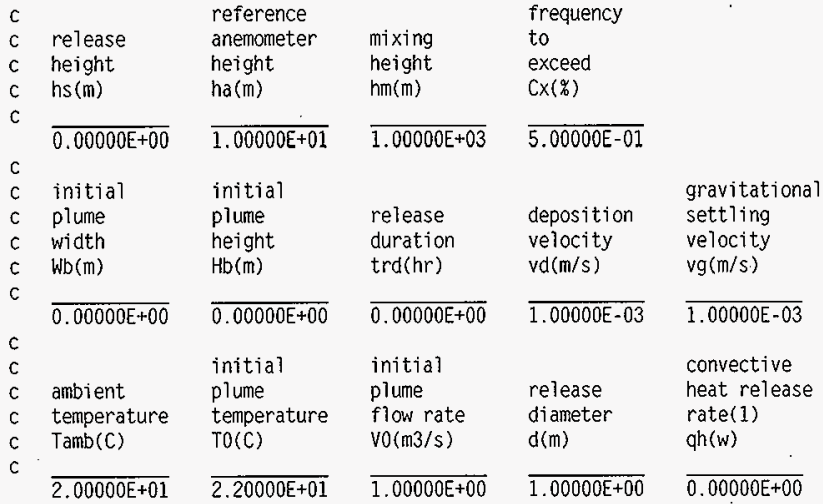

$\mathrm{C}$

c (1) If zero then buoyant flux based on plume/ambient temperature difference.

c

c $X / Q \quad$ Wind

c scaling Speed

c factor Exponent

c $c(?) \quad a(?)$

c

$$
\overline{1.00000 E+00} \quad \overline{7.80000 E-01}
$$

C

C RECEPTOR DEPENDENT DATA (no Tine limit)

c FOR MODE make RECEPTOR DEPENDENT DATA

C 1 (site specific) sector distance receptor-height

c 2 (by class \& wind speed) class windspeed distance of fset receptor-height

c 3 (create plot file) class windspeed $x \max i \max y \max$ jmax xomin power

C

C RECEPTOR PARAMETER OESCRIPTION

c sector $=0,1,2 \ldots$ (al1, S, SSW. etc.)

c distance $=$ receptor distance $(m)$

$c$ receptor height $=$ height of receptor $(m)$

C class $=1,2,3,4,5,6,7$ (P-G stability class A, B, C. D, E, F, G)

$c$ windspeed $=$ anemometer wind speed $(\mathrm{m} / \mathrm{s})$

$c$ offset $=$ offset from plume centerline (m)

$c x \max =$ maximum distance to plot or calculate to (m)

$c$ imax $=$ distance intervals

c $y \max =$ maximum offset to plot (m)

c jmax $=$ offset intervals

c $x$ amin $=$ minimum scaled $x / Q$ to calculate

$c$ power $=$ exponent in power function step size

$0100 \quad 0$

$\rightarrow$ 
HNF-2761, Rev. 0

\subsubsection{GENII Input File}

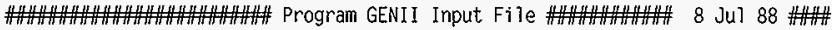
Title: PNNL HEPA Filter Box - On and Offsite IGENII $\backslash$ hepabox. in

Created on $01-22-1990$ at $07: 30$

\begin{tabular}{|c|c|c|c|}
\hline Near-fjeld scenario? & (Far-field) & NEAR-FIELD: & narrowly-focused \\
\hline Population dose? & (Individual) & & release, single site \\
\hline $\begin{array}{l}\text { Acute release? } \\
\text { Maximum Individual }\end{array}$ & $\begin{array}{l}\text { (Chronic) } \\
\text { set used }\end{array}$ & FAR-FIELD: & $\begin{array}{l}\text { wide-scale release, } \\
\text { multiple sites }\end{array}$ \\
\hline
\end{tabular}

TRANSPORT OPTIONS $=2=0$ Complete

Complete

TRANSPORT OPTIONS $==========$ Section EXPOSURE PATHWAY OPTIONS $=====$ Section

T Air Transport 1 F Finite plume, external 5

F Surface Water Transport 2 T Infinite plume, external 5

$F$ Biotic Transport (near-field) $3.4 \quad F$ Ground. external 5

F Waste Form Degradation (near) 3.4 F Recreation, external 5

REPORT OPTIONS $===================$ F Prinking water ingestion $\quad 7,6$

$T$ Report AEDE only $F$ Aquatic foods ingestion 7.8

$F$ Report by radionuclide F Terrestrial foods ingestion 7.9

F Report by exposure pathway $\quad F$ Animal product ingestion 7,10

$F$ Debug report on screen $F$ Inadvertent soil ingestion

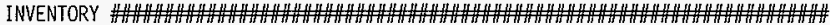

4 Inventory input activity units: (1-pCi $2-u C i \quad 3-\mathrm{mCi} \quad 4-\mathrm{Ci} \quad 5-\mathrm{Bq})$

0 Surface soil source units (1- $\mathrm{m} 2$ 2- $\mathrm{m} 3 \quad 3-\mathrm{kg}$ )

Equi 7 ibrium question goes here

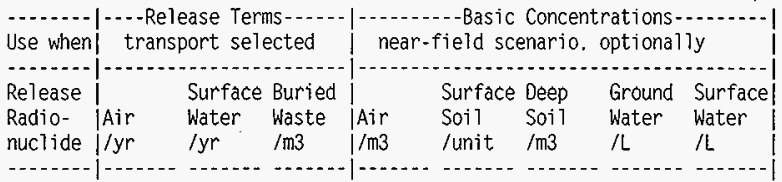

SR90 1.71E-01

Y $90 \quad 1.71 \mathrm{E}-01$

C060 $1.99 \mathrm{e}-03$

CS137 $1.13 \mathrm{e}-01$

EU154 2.86e-03

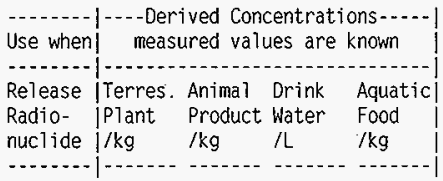

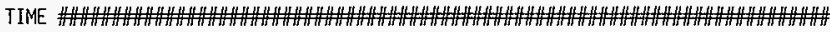

1 Intake ends after (yr)

50 Dose calc: ends after (yr)

1 Release ends after (yr)

0 No. of years of air deposition prior to the intake period

0 No. of years of irrigation water deposition prior to the intake period

FAR-FIELD SCENARIOS (IF POPULATION DOSE) 
HNF-2761; Rev. 0

\section{NEAR-FIELD SCENARIOS \#\#\#}

Prior to the beginning of the intake period: (yr)

0 When was the inventory disposed? (Package degradation starts)

$0 \quad$ When was LolC? (Biotic transport starts)

$0 \quad$ Fraction of roots in upper soil (top $15 \mathrm{~cm}$ )

$0 \quad$ Fraction of roots in deep soil

0 Manual redistribution: deep soil/surface soil dilution factor

$0 \quad$ Source area for external dose modification factor (m2)

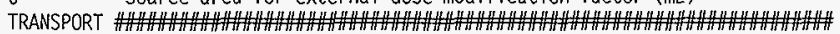

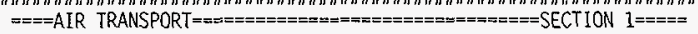

1

4.21e-2

7

100 .

$\mathrm{I}$

0

0

0

0

0

0

0

0

0

0 .

0
0
0

$T$
$T$
0
0 -Calculate PM
Option: 1 -Use chi/Q or PM value 10 2-Select MI dist \& dir 10 3-Specify MI dist \& dir 10

Chi $/ Q$ or $P M$ value

MI sector index $(1=\$)$

MI distance from retease point (m) 0

Use jf data. (T/F) else chi/0 gridlo
Release type $(0-3)$

Stack release (T/F)

Stack height (m)

Stack flow $(\mathrm{m} 3 / \mathrm{sec})$

Stack radius (m)

Effluent temp. (c)

Building $x$-section (m2)

Building height (m)

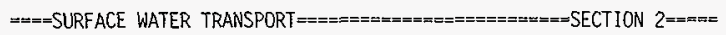
Mixing ratio mode1: 0-use value, 1-river, 2-lake

Mixing ratio, dimensionless

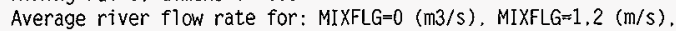

Transit time to irrigation withdrawl location $(\mathrm{hr})$

If mixing ratio model $>0$ :

Rate of effluent discharge to receiving water body $(\mathrm{m} 3 / \mathrm{s})$

Longshore distance from release point to usage location. (m)

Offshore distance to the water intake (m)

Average water depth in surface water body ( $(\mathrm{m})$

Average river width (ii). MIXFLG=1 only

Depth of effluent discharge point to surface water $(\mathrm{m})$. lake only

$===$ WASTE FORM AVAILABILITY $==========\pi============$ SECTION $3====$ Waste form/package half life, (yr)

Waste thickness. (m)

Depth of soil overburden. m

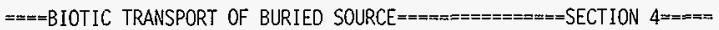
Consider during inventory decay/buildup period (T/F)?

Consider during intake period (T/F)? | 1-Arid non agricultural

Pre-Intake site condition........... 2 2-Humid non agricultura]

| 3-Agricultural

EXPOSURE

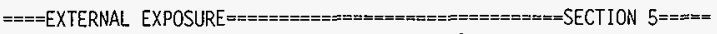

Exposure time:

Plume (hr)

I Residential irrigation:

0

0

0

0

0

0

8766.0

Soil contamination (hr)

Swimming (hr)

Boating (hr)

I Consider: (T/F)

10 Source: 1-ground water

2-surface water

Application rate (in/yr)

Shoreline activities ( $h r) \mid 0$ Duration (mo/yr)

Shoreline type: (1-river, 2-lake, 3-ocean, 4-tidal basin)

Transit time for release to reach aquatic recreation (hr)

Average fraction of time submersed in acute cloud (hr/person $\mathrm{hr}$ )

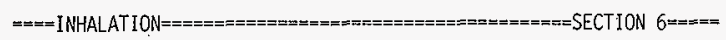

Hours of exposure to contamination per year 
HNF-2761, Rev. 0

\begin{tabular}{|c|c|}
\hline & $\begin{array}{ccc}0 \text {-No resus- } & \text { 1-Use Mass Loading } & \text { 2-Use Anspaugh model } \\
\text { pension } & \text { Mass loading factor }(\mathrm{g} / \mathrm{m} 3) & \text { Top soil available }(\mathrm{cm})\end{array}$ \\
\hline & 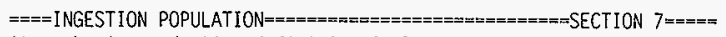 \\
\hline & Atmospheric production definition (select option): \\
\hline 0 & $\begin{array}{l}\text { 0-Use food-weighted chi/Q, (food-sec/m3), enter value on this line } \\
\text { 1-Use population-weighted chi/Q } \\
\text { 2-Use uniform production } \\
\text { 3-Use chi/Q and production grids (PRODUcTION will be overridden) }\end{array}$ \\
\hline & Population ingesting aquatic foods, 0 defaults to total (person) \\
\hline & Population ingesting drinking water. 0 defaults to total (person) \\
\hline & Consider dose from food exported out of region (defaul $t=F$ ) \\
\hline
\end{tabular}

$====$ AQUATIC FOODS / DRINKING WATER INGESTION $========$ SECTION $8====$

F Salt water? (default is fresh)

\begin{tabular}{|c|c|c|c|c|c|c|c|}
\hline USE & & TRAN- & PROD- & - CONSUM & PTION- & & \\
\hline ? & FOOD & SIT & UCTION & HOLDUP & RATE & & \\
\hline$T / F$ & TYPE & $h r$ & $\mathrm{~kg} / \mathrm{yr}$ & da & $\mathrm{kg} / \mathrm{yr}$ & & ORINKING WATER \\
\hline $\mathrm{F}$ & FISH & 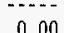 & $000 \mathrm{at}+00$ & 00 & 0 & 0 & Sourc \\
\hline $\mathrm{F}$ & MOLLUS & 0.00 & $0.0 E+00$ & 0.00 & 0.0 & $\mathrm{~T}$ & Treatment? T/F \\
\hline $\mathrm{F}$ & CRUSTA & 0.00 & $0.0 E+00$ & 0.00 & 0.0 & 0 & Holdup/transit(da) \\
\hline $\mathrm{F}$ & PLANTS & 0.00 & $0.0 \mathrm{E}+00$ & 0.00 & 0.0 & 0 & Consumption (L/yr) \\
\hline
\end{tabular}

$====$ TERRESTRIAL FOOD INGESTION====================3ECTION $9=====$

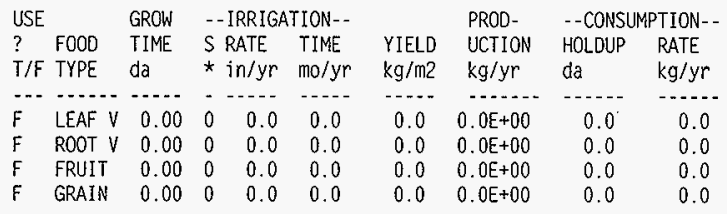

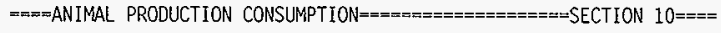

\begin{tabular}{|c|c|c|c|c|c|c|c|c|c|c|}
\hline \multirow{4}{*}{$\begin{array}{l}\text { FOOD } \\
\text { TYPE }\end{array}$} & \multicolumn{2}{|c|}{$\cdots$ HUMAN- - - } & \multirow{3}{*}{$\begin{array}{l}\text { TOTAL } \\
\text { PROD- } \\
\text { UCTION }\end{array}$} & \multirow{3}{*}{$\begin{array}{l}\text { DRINK } \\
\text { WATER } \\
\text { CONTAM }\end{array}$} & \multicolumn{4}{|c|}{ 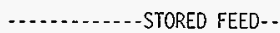 } & \multicolumn{2}{|c|}{ - } \\
\hline & CONSU: & MPTION & & & DIET & GROW & -IRRIGA & TION- - & & STOR- \\
\hline & RATE & HOLDUP & & & FRAC- & TIME & $S$ RATE & TIME & YIELD & AGE \\
\hline & $\mathrm{kg} / \mathrm{yr}$ & da & $\mathrm{kg} / \mathrm{yr}$ & FRACT. & JION & $\mathrm{da}$ & * $\mathrm{jn} / \mathrm{yr}$ & $\mathrm{mo} / \mathrm{yr}$ & $\mathrm{kg} / \mathrm{m} 3$ & da \\
\hline & & & & 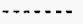 & & & & & & \\
\hline BEEF & 0.0 & 0.0 & 0.00 & 0.00 & 0.00 & 0.0 & 0.0 & 0.00 & 0.00 & 0.0 \\
\hline POULTR & 0.0 & 0.0 & 0.00 & 0.00 & 0.00 & 0.0 & 0.0 & 0.00 & 0.00 & 0.0 \\
\hline MILK & 0.0 & 0.0 & 0.00 & 0.00 & 0.00 & 0.0 & 0.0 & 0.00 & 0.00 & 0.0 \\
\hline$E G G$ & 0.0 & 0.0 & 0.00 & 0.00 & 0.00 & 0.0 & 0.0 & 0.00 & 0.00 & 0.0 \\
\hline BEE & & & & & 0.0 & 0.0 & 0.0 & 00 & 0.00 & 00 \\
\hline MILK & & & & & 0.00 & 0.0 & 0.0 & 0.00 & 0.00 & 0.0 \\
\hline
\end{tabular}




\section{CHECKLIST FOR CHECKING OF ANALYSIS/CALCULATIONS}

Document Number/Revision: HNF-2761 Rev 0

Document Title: Radiological Risk Evaluation and Dose Consequence Analysis for the PNNL Hepa Filter Box SEP (Sections B3 and B4.6)

Yes No N/A

[x] [] [] Problem completely defined.

[x] [ ] [ ] Appropriate analytical method used.

[x] [ ] [ ] Necessary assumptions are appropriate and explicitly stated.

[x] [ ] [ ] Computer codes and data files documented.

[x] [ ] [ ] Data used in calculations explicitly stated in document.

[ 1 [ ] [x] Sources of non-standard formula/data are referenced and the correctness of the reference verified.

[x] [ ] [ ] Data checked for consistency with original source information as applicable.

[x] [ ] [ ] Mathematical derivations checked including dimensional consistency of results.

[x] [ ] [ ] Models appropriate and used within range of validity or use outside range of established validity justified.

[x] [ ] [ ] Hand calculations checked for errors.

[x] [ ] [ ] Code run streams correct and consistent with analysis documentation.

[x] [ ] [ ] Code output consistent with input and with results reported in analysis documentation.

[x] [ ] I] Acceptability limits on analytical results applicable and supported. Limits checked against sources.

[x] [ ] [ ] Safety Margins consistent with good engineering practices.

[x] [ ] [ ] Conclusions consistent with analytical results and applicable limits.

[x] [ ] [ ] Results and conclusions address all points required in the problem statement.

I have checked the analysis/calculation and it is complete and accurate to the best of my knowledge.

Engineer/Checker_J.G. McFadden

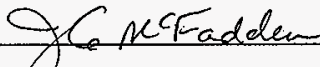
Date $6 / 4 / 98$

NOTE: Any hand calculations, notes or summaries Generated as part of this check should be signed, dated, and attached to this checklist. Material should be labeled and recorded so that it is intelligible to a technically qualified third party. 
HNF-2761, Rev. O

This page intentionally left blank.

B4-14 


\subsection{SHIELDING EVALUATION}

\subsection{INTRODUCTION}

The Pacific Northwest HEPA Filter Box will be used to transport eight HEPA filters from the Hanford 300 Area to the solid waste burial ground or the Central Waste Complex in the 200 West Area. The package consists of an inner and an outer steel box. The inner box contains four filters that are contaminated while the other four filters, which had no detectable contamination, are packed between the inner and outer boxes.

Although the source term was reported by Pacific Northwest (see Part B, Section 2.0, and Part A, Section 10.01, the distribution of the radionuclides inside the box are not known.

Therefore, a survey was conducted to determine the maximum surface dose rate on the box (see Part $B$, Section 5.2). The results indicate that the maximum surface dose is $0.8 \mathrm{mSv} / \mathrm{h}$ $(80 \mathrm{mrem} / \mathrm{h})$ and occurs on the top of the box.

The dose rate limits for exclusive-use transport are $10 \mathrm{mSv} / \mathrm{h}(1,000 \mathrm{rem} / \mathrm{h})$ at the surface of the package, $0.01 \mathrm{mSv} / \mathrm{h}(10 \mathrm{mrem} / \mathrm{h})$ at a distance of $2 \mathrm{~m}$ from the vehicle, and $0.02 \mathrm{mSv} / \mathrm{h}$ $(2 \mathrm{mrem} / \mathrm{h})$ for the driver if a nonradiation worker or $0.05 \mathrm{mSv} / \mathrm{h}(5 \mathrm{mrem} / \mathrm{h})$ for a Hanford radiation worker. As shown in the survey report (Part B, Section 5.2), the maximum dose rate measured at the surface of the box was $0.8 \mathrm{mSv} / \mathrm{h}(80 \mathrm{mrem} / \mathrm{h})$. At a distance of $30 \mathrm{~cm}$, the dose rate falls off to $0.5 \mathrm{mSv} / \mathrm{h}(50 \mathrm{mrem} / \mathrm{h})$, a factor of 0.625 less than the surface dose rate. Assuming the dose rate falls off linearly (a conservative assumption), at a distance of $2 \mathrm{~m}$, the dose rate will be approximately $0.035 \mathrm{mSv} / \mathrm{h}(3.5 \mathrm{mrem} / \mathrm{h})$, well within the limits. No estimate of the dose to the driver was completed because the vehicle to be used is not yet defined. Therefore, supplemental shielding may be added to meet the dose rate fimits to the driver. 
HNF-2761, Rev. 0

\subsection{APPENDIX: SURVEY REPORT}

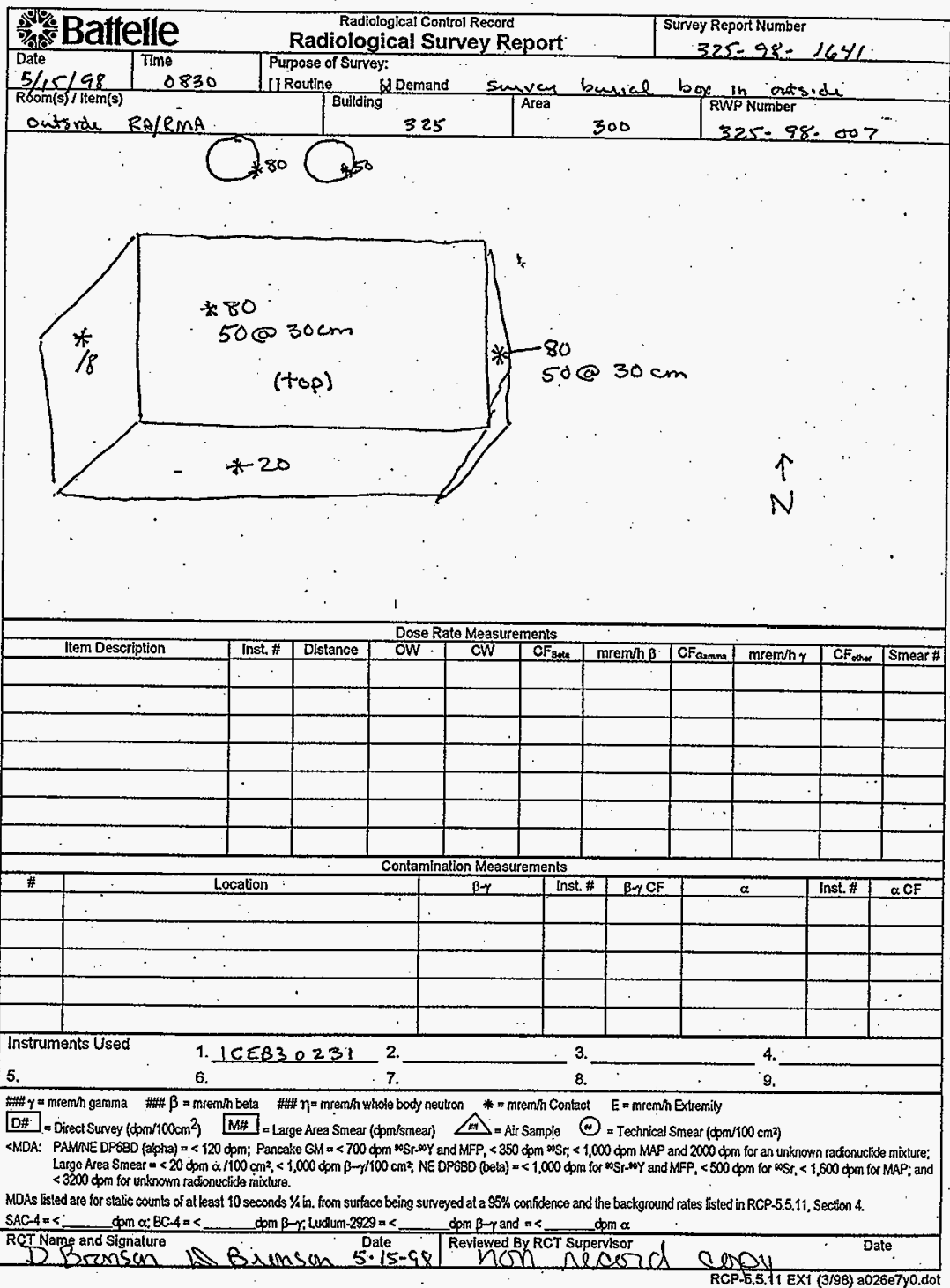


HNF-2761, Rev. 0

\subsection{CRITICALITY EVALUATION} required.

There is no fissile material in the Pacific Northwest HEPA Filter Box, so no evaluation is 
HNF-2761, Rev. 0

This page intentionally left blank.

B6-2 
HNF-2761, Rev. 0

\subsection{STRUCTURAL EVALUATION}

\subsection{INTRODUCTION}

A strong-tight box procured for transporting low specific activity (LSA) material will be used to transport HEPA filters from the 300 Area to the 200 Area burial grounds on the Hanford Site. The strong-tight box contains a heavy inner shielding box containing used filters. There are also some unused filters in the package that are not in an inner box, but they are not of concern because they are very light compared to the shielding box and have no radioactive material in them. This evaluation is required because (1) the gross weight of the package exceeds the gross weight stated on the procurement specification and (2) the contents do not meet LSA requirements.

\subsection{STRUCTURAL EVALUATION OF THE PACKAGE}

\subsubsection{Structural Description of Package}

The outer strong-tight box has maximum overall dimensions of $2.55 \mathrm{~m}$ (100.5 in.) in length, $1.35 \mathrm{~m}$ (53.2 in.) in width, and $1.64 \mathrm{~m}$ (64.5 in.) in height. It is fabricated from mild carbon steel sheet $2.67 \mathrm{~mm}$ thick (12 gage, $0.1046 \mathrm{in.}$ ) and has flanges made from structural steel angles $38 \mathrm{~mm}$ (1.5 in.) by $38 \mathrm{~mm}$ (1.5 in.) by $6.4 \mathrm{~mm}(0.25 \mathrm{in}$.) with 18 boits securing the lid to the body. See Figure B7-1 for the flange and seal details. The box was procured by Pacific Northwest as a strong-tight shipping box to ship LSA material under the rules of 49 CFR 173.

The bottom of the strong-tight box has four riser channels made of 12-gage sheet steel that provide a forklift pocket $76 \mathrm{~mm}(3.0 \mathrm{in})$ high and three lift bails on the lid. The riser channels are attached by their legs (the channel's web is on the ground) to the bottom with fillet welds. These are skip welds $38 \mathrm{~mm}$ (1.5 in.) long that are located every $305 \mathrm{~mm}$ (12.0 in.), and there is a weld on both legs of the channel. The lift bails are 12-gage material bent into a channel $51 \mathrm{~mm}(2.0 \mathrm{in}$.) wide and welded to the top of the lid.

The steel sheet used in the box is noted as ASTM-569 steel sheet (see drawings in Part A, Section 10.3). The lid angles are noted as ASTM A36, and the bolts are noted as "grade 5 plated" and are assumed to be Society of Automotive Engineers grade 5.

The lid seal is an ethylene-propylene diene monomer (EPDM) strip $25 \mathrm{~mm}$ (1.0 in.) wide and $4.8 \mathrm{~mm}(3 / 8 \mathrm{in}$.$) thick. Using the theoretical dimensions from the drawing, the gasket is$ compressed $1.6 \mathrm{~mm}(1 / 16 \mathrm{in}$.$) when the flange angles are in full contact.$

The shield box is stated as being welded steel with a bolted lid having the following plate thickness: the top is $51 \mathrm{~mm}(2 \mathrm{in.})$, the bottom is $57 \mathrm{~mm}(2.25 \mathrm{in}$.$) , and the four sides are 38 \mathrm{~mm}$ (1.5 in.).

\subsubsection{Chemical and Galvanic Reactions}

The boxes are painted, and the lid bolts are plated for corrosion resistance. The riser channels have kept the bottom of the box from standing water. 
HNF-2761, Rev. 0

Figure B7-1. HEPA Filter Box.

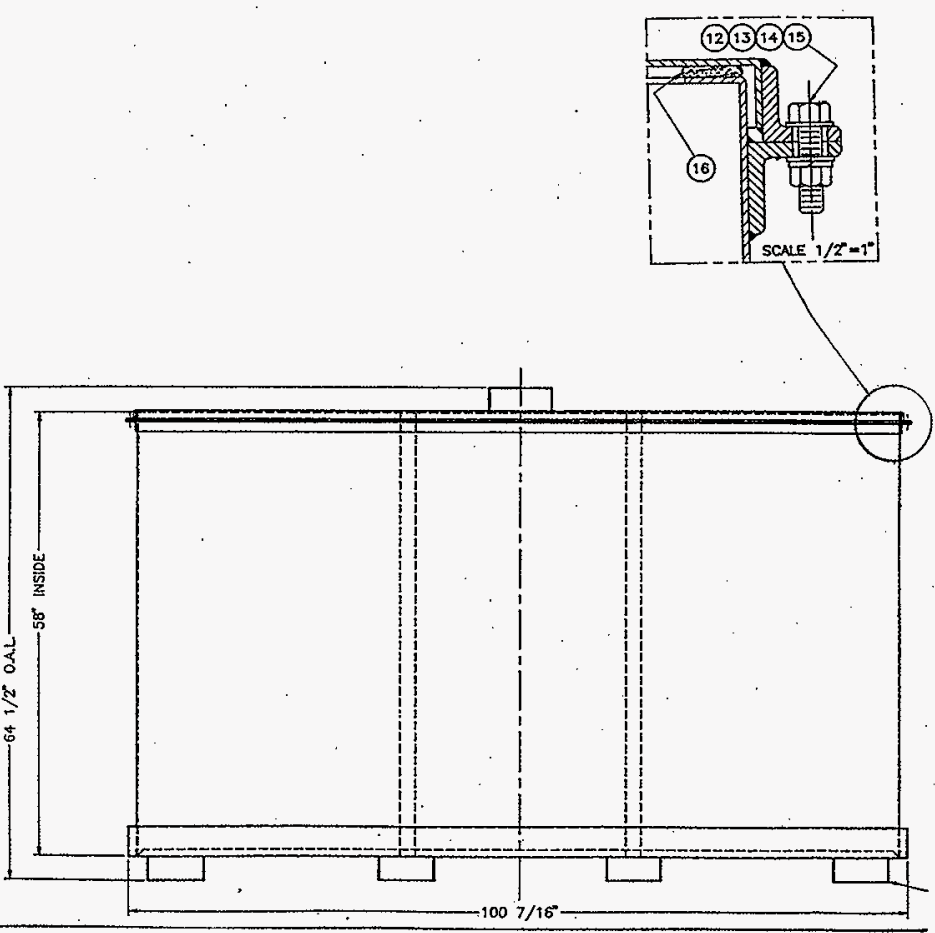




\subsubsection{Size of Package and Cavity}

The drawing in Part A, Section 10.3, of this SEP shows the external dimensions to be $2.55 \mathrm{~m}$ (100.5 in.) long, $1.35 \mathrm{~m}$ (53.2 in.) wide, and $1.64 \mathrm{~m}(64.5 \mathrm{in}$.) high overall. These include the forklift pocket and the lid lift bails. The inside dimensions are $2.45 \mathrm{~m}$ (98.0 in.) long, $1.27 \mathrm{~m}$ (50.0 in.) wide, and $1.47 \mathrm{~m}$ (58.0 in.) high. Figure B7-1 shows a longitudinal section of the box.

The shield box's inside dimensions are stated to be $1.70 \mathrm{~m}(5.58 \mathrm{ft}) \mathrm{long}, 0.838 \mathrm{~m}$ wide $(2.75 \mathrm{ft})$, and $1.30 \mathrm{~m}(4.25 \mathrm{ft})$ high.

\subsubsection{Weight}

The calculated package weight is $4,947 \mathrm{~kg}(10,907 \mathrm{lb})$. This includes the contents weight of $454 \mathrm{~kg}(1,000 \mathrm{lb})$, the inner box weight of $4,015 \mathrm{~kg}(8,852 \mathrm{lb})$, and the outer box weight of $479 \mathrm{~kg}(1,055 \mathrm{lb})$. The weight of the contents, inner box, and total gross weight are provided by Pacific Northwest. The inner box weight is confirmed by calculations in the appendix (Part B, Section 7.5), using dimensional data also provided by Pacific Northwest. The calculation shows that the inner box weight provided by Pacific Northwest is consistent with the dimensions and is used for load calculations.

The vertical center of mass is located $69.0 \mathrm{~cm}(27.1 \mathrm{in})$ above the bottom of the package (the bottom of the channels). If the inner box was centered within the outer, the horizontal position of the center of mass would coincide with the geometric center of the outer box. But if the inner box is as far from the center as possible, the package center of mass would be located $33.0 \mathrm{~cm}$ (13.0 in.) longitudinally and $16.0 \mathrm{~cm}(6.3 \mathrm{in.})$ laterally from the geometric center.

\subsubsection{Tamper-Indicating Devices}

There are no tamper-indicating devices noted.

\subsubsection{Positive Closure}

There are 18 grade 5 bolts and nuts $3 / 8$ in. in size. When properly torqued they will provide positive closure because the vibration loading will be small compared to the preload force.

\subsubsection{Lifting and Tiedown Devices}

The lifting bails on the box lid shall not be used for lifting the package or securing the package to the conveyance. The riser channels shall not be used to secure the loaded box to a vehicle, but the risers may rest against blocking.

\subsection{NORMAL TRANSFER CONDITIONS}

\subsubsection{Conditions To Be Evaluated}

Onsite structural performance of the package is assessed for Hanford Site normal conditions in this section. The onsite conditions evaluated for are hot and cold temperature extremes, reduced and increased external pressure, vibration, water spray, compression, inertial loading, and penetration. The package structural response with solar insolation is evaluated for the onsite hot 
HNF-2761, Rev. 0

ambient temperature extreme of $46^{\circ} \mathrm{C}\left(115^{\circ} \mathrm{F}\right)$ and for the cold extreme of $-33^{\circ} \mathrm{C}\left(-27^{\circ} \mathrm{F}\right)$ (Irwin 1996). Reduced and increased external pressure structural response is evaluated for a Hanford Site maximum barometric pressure range of $0.94 \mathrm{~atm}$ (13.81 psi) to $1.01 \mathrm{~atm}$ (14.85 psi). Vibrational loading response of the package is evaluated for the parameters established in ANSI N14.23 (ANSI 1992). Since this will be an exclusive-use shipment without stops or transloading, structural response of the package to inertial loads is evaluated for normal transport based on ANSI (1992) shock loading. Penetration is evaluated using a steel rod $3.2 \mathrm{~cm}(1.25 \mathrm{in}$.) in diameter with a rounded end, weighing $6 \mathrm{~kg}(13 \mathrm{lb})$ and dropping onto the package from a height of $1.0 \mathrm{~m}$ (40.0 in).

\subsubsection{Acceptance Criteria}

The criterion for acceptable structural performance of the package is for the inner box to remain contained. This will be demonstrated by the package having positive margins of safety for the requirements of B\&PVC, Section III, Subsection NE (ASME 1995b) for level A service (design conditions). Fracture toughness is evaluated using NRC Regulatory Guide 7.11 (NRC 1991a) criteria.

\subsubsection{Hot and Cold Evaluation}

Based on the thermal evaluation from Part B, Section 8.0, of this SEP, the maximum box temperature will be $64^{\circ} \mathrm{C}\left(147^{\circ} \mathrm{F}\right)$ due to solar heating combined with the internal heating of the contents. This is within the service temperature range for EPDM rubber (Parker 1992). B\&PVC, Section II, Part D (ASME 1995a), shows that SA-285, a carbon steel similar to that used in the package, shows no decrease in Sm or tensile strength up to $343^{\circ} \mathrm{C}\left(650^{\circ} \mathrm{F}\right)$, so the steel box will not show a decrease in performance due to the hot-temperature conditions. The box will experience an internal pressure increase of $13.8 \mathrm{kPa}(2.0 \mathrm{psi})$ due to this temperature. This is combined with the $1.03 \mathrm{kPa}(0.15 \mathrm{psi})$ pressure due to a drop of atmospheric pressure, and calculations shown in the appendix (Part B, Section 7.5) show that the resulting stresses in the package are less than those allowed for B\&PVC, Section III, Subsection NE (ASME 1995b), level A service.

Pressure decrease in the box due to cold-condition temperatures were not evaluated since the package will be shipped during the summer.

The box material is carbon steel, so brittle fracture is evaluated at the cold-condition temperature of $-33^{\circ} \mathrm{C}\left(-27^{\circ} \mathrm{F}\right)$. NRC Regulatory Guide 7.11 (NRC 1991a) and NUREG/CR 1815 (NRC 1991b) establish three levels of fracture toughness criteria based on contents. Since the package contains less than $30 \mathrm{~A}_{2}$ values and less than $30,000 \mathrm{Ci}$, the lowest safety level, Category [II, would be applied (NRC 1991a), and ferritic steel is not tested for fracture toughness when its yield strength is less than $690 \mathrm{MPa}(100 \mathrm{ksi})$ and its thickness is less than $10 \mathrm{~mm}$ (0.4 in.). Therefore, the package meets the brittle fracture criteria; and there are no low-temperature restrictions.

\subsubsection{Reduced and Increased External Pressure}

Calculations in the appendix (Part B, Section 7.5) find the effects of pressure due to atmospheric pressure change combined with the maximum temperature-induced pressure increase within the box. The evaluation shows that the external pressure decrease combined with the pressure increase within the box due to hot conditions will not decrease the performance of the package. 


\subsubsection{Vibration}

This is a one-time shipment with a distance of about $48.3 \mathrm{~km}(30.0 \mathrm{mi})$. Using a typical truck suspension system response frequency of $2 \mathrm{~Hz}$ and a travel time of 1 hour, the package will experience fewer than 7,200 cycles, so vibration will have a negligible effect on the package. ANSI N14.23 (ANSI 1992) vibration forces due to NTC were applied to the lid, and the resulting forces were added to the bolt forces due to pressure. Under this combination, the bolts still met the stress requirements of B\&PVC, Section III, Subsection NE (ANSI 1995b), with a margin of safety.

\subsubsection{Water Spray}

The steel box material is not affected by water spray. Figure B7-1 shows that the gasket and the lid flanges together will prevent water in-leakage due to water spray.

\subsubsection{Compression}

Because the box is shipped by itself as an exclusive-use shipment, package compression is not a concern.

\subsubsection{Inertial Loading}

No in-transit transfers will occur during transport of this package so only NTC are evaluated. The calculations in the appendix (Part B, Section 7.5) demonstrate that the package will meet the intent of ANSI standard N14.23 (draft [ANSI 1992]) for shock loading due to normal highway transportation. Assuming that the inner box is either against the outer box or blocked and braced in the outer box, the package will not fail when subjected to a static $2.3 g$ longitudinal acceleration. The calculations consider the effects of the heavy inner box bearing on one end wall of the strongtight box and assume that the inner box is prevented from sliding within the strong-tight box by dunnage or the uncontaminated filters.

\subsubsection{Penetration}

The calculations in the appendix (Part B, Section 7.5) show that sheet steel thicker than $0.81 \mathrm{~mm}(0.032 \mathrm{in}$.) would resist penetration by the test rod. Since the 12-gage material is $2.66 \mathrm{~mm}(0.1046 \mathrm{in}$.$) thick, the test rod will not penetrate the package, and the criteria is met.$

\subsubsection{Conclusions}

The results of these evaluations show the package is acceptable for transport on the Hanford Site under NTC. 
HNF-2761, Rev. 0

\subsection{REFERENCES}

49 CFR 173, "Shippers--General Requirements for Shipments and Packagings," Code of Federal Regulations, as amended.

ANSI, 1992, Draft American National Standard Design Basis for Resistance to Shock and Vibration or Radioactive Material Packages Greater than One Ton in Truck Transport, ANSI N14.23, American National Standards Institute, New York, New York.

ASME, 1995a, Boiler and Pressure Vessel Code, Section II, Part D, American Society of Mechanical Engineers, New York, New York.

ASME, 1995b, Boiler and Pressure Vesse/ Code, Section III, Subsection NE, American Society of Mechanical Engineers, New York, New York.

Irwin, J. J., 1996, Thermal Analysis Methods for Safety Analysis Reports for Packaging, WHC-SD-TP-RPT-005, Rev. 1, Westinghouse Hanford Company, Richland, Washington.

NRC, 1991a, Fracture Toughness of Base Material for Ferritic Steel Shipping Cask Containment Vessels with a Maximum Wall Thickness of 4 Inches $(0.1 \mathrm{~m})$, Regulatory Guide 7.11, U.S. Nuclear Regulatory Commission, Washington, D.C.

NRC, 1991b, Recommendations for Protecting Against Failure by Brittle Fracture in Ferritic Steel Containers up to 4 Inches Thick, NUREG/CR 1815, prepared by Lawrence Livermore National Laboratory for the U.S. Nuclear Regulatory Commission, Livermore, California.

Parker, 1992, Parker O-Ring Handbook, Parker Seals Group, O-Ring Division, Lexington, Kentucky. 


\subsection{APPENDIX: STRUCTURAL ANALYSIS}

\section{ENGINEERING SAFETY EVALUATION}

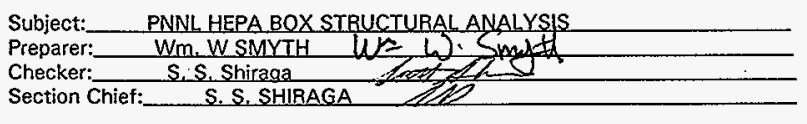

Page Date 1 June 98 Date 1 June 98 Date 1 June 98

\subsection{OBJECTIVE}

Find the weight, volume, and center of mass of the PNNL HEPA box. PNNL provided weight information for the contents and an inner shield box, and dimensions for the inner box. The inner box weight is calculated since there was uncertainty in the box that was used for comparison with the weight provided.

\subsection{REFERENCES}

SRC, 1996: drawings for model 165-12-10 box by S. C. S. Incorporated, rev A, 1996

\subsection{ASSUMPTIONS, RESULTS, AND CONCLUSIONS}

The calculated total package weight is $4947 \mathrm{~kg}(10,907 \mathrm{lb})$. This includes the contents weight of $454 \mathrm{~kg}(1000 \mathrm{lb})$, the inner box weight of $4015 \mathrm{~kg}(8852 \mathrm{lb})$, and the outer box weight of $479 \mathrm{~kg}(1055 \mathrm{lb})$. The calculated inner box weight was less than that provided by PNNL, so the larger PNNL weight was used for all further calculations. The differences are due to not knowing how far the sides of the box extend past the ends for a fillet weld. Using the inner dimensions plus wail thickness for calculating the center of mass, neglecting the side extensions, is conservative since the calculated center of mass of the package will be further from the geometric center than it actually is.

The weights are dominated by the inner box, and its position inside the outer box will determine the position of the center of mass. Assuming that the inner box is completely filled, and the content's weight is uniformly distributed within the inner box, the vertical center of mass is located 27.1 in above the bottom of the package (the bottom of the channels). If the inner box were centered within the outer, the horizontal position of the center of mass would coincide with the geometric center of the outer box; but if the inner box is as far from the center as possible, the package center of mass would be located 33.0 $\mathrm{cm}$ longitudinally and $16.0 \mathrm{~cm}$ laterally ( $13 \mathrm{in}, 6.3 \mathrm{in}$ ) from the geometric center. 
HNF-2761, Rev. 0

ENGINEERING SAFETY EVALUATION

Subject:

Preparer:

PNNL HEPA BOX STRUCTURAL ANALYSIS

Checker:

WI. W SMYTH

vive

Section Chief:

S.S. SHIRAGA

Page 2 of 4

Date 1 June 98

Date 1 June 98

Date 1. June 98

\section{0 evaluation}

Dimensional calculations for HEPA BOX

Inner:

$$
\begin{aligned}
& \rho:=500 \cdot \frac{\mathrm{lb}}{\mathrm{ft}^{3}} \quad \text { Lin }:=5.583 \cdot \mathrm{ft} \quad \text { Win }:=2.75 \cdot \mathrm{ft} \quad \mathrm{Tb}:=2.25 \cdot \text { in } \quad \mathrm{Tt}:=2 \cdot \text { in } \\
& \text { density, outer length and width, bottom and top thickness: inner dimensio } \\
& \text { Hin }:=4.25 \cdot \mathrm{ft} \quad \mathrm{T} 3:=1.5 \cdot \mathrm{in} \quad \mathrm{Ws} 1:=(\operatorname{Lin}+2 \cdot \mathrm{T} 3+2 \cdot \mathrm{in}) \cdot(\mathrm{Hin}) \cdot \mathrm{T} 3 \cdot \rho \quad \mathrm{Ws} 1=1594 \cdot \mathrm{lb} \\
& \text { height, side thickness, side weight } \\
& \text { Ws }:=(\text { Win }) \cdot(\mathrm{Hin}) \cdot \mathrm{T} 3 \cdot \rho^{\prime} \quad \mathrm{Ws} 2=730 \mathrm{db} \quad \text { end weight } \\
& \mathrm{Wt}:=(\mathrm{Lin}+2-\mathrm{T} 3) \cdot(\mathrm{Win}+2 \cdot \mathrm{T} 3) \cdot \mathrm{Tt} \cdot \rho \quad \mathrm{Wt} \quad 1458 \cdot \mathrm{lb} \\
& \mathrm{Wb}:=(\operatorname{Lin}+2 \cdot \Upsilon 3+2 \cdot \mathrm{in}) \cdot(\mathrm{Win}+2 \cdot \mathrm{T} 3) \cdot \mathrm{Tb} \cdot \rho \quad \mathrm{Wb}=1687 \cdot \mathrm{lb} \\
& \text { bottom \& top weight } \\
& \text { Wins }:=W t+W b+2 \cdot W s 1+2 \cdot W s 2 \quad W i n s=7794 \cdot \mathrm{lb} \quad \text { inner box wt }
\end{aligned}
$$$$
\text { According to PNNL information, use Wins := 8852-1b Wins }=4015 \cdot \mathrm{kg}
$$

volume of inner box: $\operatorname{Lir}$ WirHin $=1.85 \cdot \mathrm{m}^{3} \quad$ this mached PNNL data

PNNL's weight for the inner box is larger than the calculated weight, probably due to lack of information about the inner box's configuration. The PNNL weight is used for further calculations. 


Subject: $\quad$ PNNL HEPA BOX STRUCTURAL ANALYSIS
Preparer:- WM. W SMYTH U.
Checker:
Section Chief:S. Shiraga
S.S. SHIRAGA

Page 3 of $\frac{4}{1 \text { June } 98}$
Date $\frac{1 \text { June } 98}{\text { Date } 1 \text { June } 98}$
Date_ 1 J

Outer box

$$
\begin{aligned}
& I:=.1046 \cdot \text { in } \quad I:=98.75 \cdot \text { in } \quad W:=50 \cdot \text { in } \quad H:=58 \cdot \text { in } \\
& W 1:=(L \cdot W \cdot 2 \cdot T \cdot \rho)+2 \cdot H \cdot W \cdot T \cdot p+2 \cdot L \cdot H \cdot T \cdot \rho \quad W 1=821 \cdot 1 b \quad 6 \text { sides } \\
& \mathrm{W} 2:=4 \cdot \mathrm{T} \cdot 52.5 \cdot \mathrm{in} \cdot 13 \cdot \operatorname{in} \mathrm{p} \quad \mathrm{W} 2=83 \cdot \mathrm{lb} \quad \text { risers } \\
& \mathrm{W} 3:=2 \cdot 52 \cdot \mathrm{in} \cdot \mathrm{T} \cdot 6 \cdot \mathrm{in} \cdot \mathrm{P} \quad \mathrm{W} 3=19 \cdot 1 \mathrm{~b} \quad \text { bottom end channels } \\
& \text { W4 }:=2 \cdot 100 \cdot \mathrm{in} \cdot T \cdot 6 \cdot \mathrm{in} \cdot \rho \quad \text { W4 }=36 \cdot 1 \mathrm{~b} \quad \text { bottom side channels } \\
& \text { W5 }:=2 \cdot 1.92 \cdot \frac{\mathrm{lb}}{\mathrm{ft}} \cdot 2 \cdot(100 \cdot \mathrm{in}+50 \cdot \mathrm{in}) \quad \text { W5 }=96 \cdot 1 \mathrm{~b} \quad \text { flanges } \\
& \text { Wout : }=\mathrm{W} 1+\mathrm{W} 2+\mathrm{W} 3+\mathrm{W} 4+\mathrm{W} 5 \quad \text { Wout }=1055 \cdot 1 \mathrm{~b} \quad \text { Wout }=479 \cdot \mathrm{kg} \\
& \mathrm{Wc}:=1000 \cdot \mathrm{lb} \quad \text { contents weight provided by PNNL } \\
& \text { Package weight: } \quad \text { Wtot }:=\text { Wins }+ \text { Wout }+ \text { Wc } \quad \text { Wtot }=10907 \mathrm{db} \\
& \text { Cavity size of outer package: } \quad L \cdot \mathrm{W} \cdot \mathrm{H}=166 \cdot \mathrm{ft}^{3} \\
& \text { Wtot } 04947 \mathrm{okg} \\
& \text { Package weight provided by PNNL weight }=\quad 10835 \cdot \mathrm{lb}=4915 \mathrm{~kg}
\end{aligned}
$$

Find the package center of mass above bottom of channells

$$
\text { outer box: } \quad \mathrm{Ylcm}:=\frac{\mathrm{W} 1 \cdot(32 \cdot \mathrm{in})+\mathrm{W} 2 \cdot 1 \cdot \mathrm{in}+(\mathrm{W} 3+\mathrm{W} 4) \cdot 5.25 \mathrm{in}+\mathrm{W} 5 \cdot 54.9 \cdot \text { in }}{\text { Wout }}
$$


HNF-2761, Rev. 0

ENGINEERING SAFETY EVALUATION

\begin{tabular}{|c|c|c|}
\hline Subject: & PNNL HEPA BOX STRUCTURAL ANALYSIS & 4 of $\quad 4$ \\
\hline Preparer: & Wm.W SMYTH WS & 1 June 98 \\
\hline Checker: & S.S. Shiraga & 1 June 98 \\
\hline Section $\mathrm{C}$ & S.S. SHIRAGA & 1 June 98 \\
\hline
\end{tabular}

inner box:

$\mathrm{Y} 2 \mathrm{~cm}:=\frac{2 \cdot(\mathrm{Ws} 1+\mathrm{Ws} 2) \cdot\left(3 \cdot \mathrm{in}+\mathrm{Tb}+\frac{\mathrm{Hin}}{2}\right)+\mathrm{Wt} \cdot\left(3 \cdot \mathrm{in}+\mathrm{Tb}+\mathrm{Hin}+\frac{\mathrm{Tt}}{2}\right)+\mathrm{Wb} \cdot\left(3 \cdot \mathrm{in}+\frac{\mathrm{Tb}}{2}\right)}{\text { Wins }}$.

contents

$\mathrm{Y} 3 \mathrm{~cm}:=\left(3 \cdot\right.$ in $\left.+\mathrm{To}+\frac{\mathrm{Fin}}{2}\right)$

$\mathrm{Y} 1 \mathrm{~cm}=30.26$ in

$\mathrm{Y} 2 \mathrm{~cm}=26.36$ in $\quad \mathrm{Y} 3 \mathrm{~cm}=30.75$ in

Vertical center of mass above floor:

$Y \mathrm{~cm}:=\frac{\text { Wout } \cdot Y 1 \mathrm{~cm}+W \text { ins } \cdot Y 2 \mathrm{~cm}+W \mathrm{c} \cdot Y 3 \mathrm{~cm}}{\text { Wtot }}$

$$
Y \mathrm{~cm}=27.14 \text { in }
$$

Find the maximum distance the horizontal center of mass can be from the center of the outer box

The inner box length is smaller than the outer by: $\quad x:=1-L i n-2 \cdot T 3 \quad x=28.75$ in

$$
\mathrm{Xcm}:=\frac{(\text { Wins }+W \mathrm{c}) \cdot \frac{\mathrm{x}}{2}}{\text { Wtot }} \quad \mathrm{Xcm}=13.0 \mathrm{in}
$$

The inner box width is smaller than the outer by:

$$
y:=W-W \text { in }-2 \cdot T 3 \quad y=14 \text {.in }
$$

$$
\mathrm{Zcm}:=\frac{(\text { Wins }+W c) \cdot \frac{y}{2}}{\text { Wtot }} \quad \mathrm{Zcm}=6.3 \text { in }
$$


HNF-2761, Rev. 0

\section{ENGINEERING SAFETY EVALUATION}

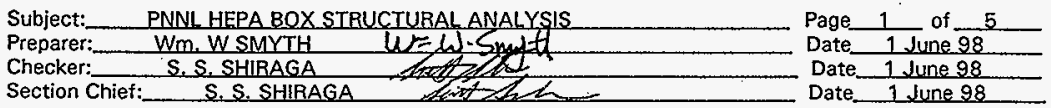

\subsection{OBJECTIVE}

Determine the effects of a 2.3g inertial load on the PNNL HEPA filter box, find the bolt stress due to an internal pressure of 2.2 psig combined with the ANSI 14.23 vibration loads, and determine whether the package will withstand the 10 CFR 71.71 penetration test.

\subsection{REFERENCES}

SRC, 1996: drawings for model 165-12-10 box by S. C. S. Incorporated, rev A, 1996

ANSI, 1992: Draft American National Standard design basis for Resistance to Shock and Vibration or Radioactive Material Packages Greater than one ton in Truck Transport.

ASME, 1992: ASME Boiler and Pressure Vessel Code, Section II, Subsection D, American Society of Mechanical Engineers, NY, 1992

Bechtel, 1974: Topical Report (BC-TOP-9A, rev 2) Design of Structures for Missile Impact, Bechtel Power Corporation, San Francisco, CA, 1974

\subsection{ASSUMPTIONS, RESULTS, AND CONCLUSIONS}

Assuming the inner box does not slide and impact the end wall of the outer box, the package will not fail when subjected to a $2.3 \mathrm{~g}$ longitudinal acceleration. Since the end wall of the package is weaker than the top or sidewalls and the ANSI standard's lateral and vertical acceleration requirements are smaller than the longitudinal requirement, the package will meet the intent of ANSI standard NI4.23 (draft) for shock loading due to normal highway transportation. The welded corner joint was considered to be the weak point of the structure since the sheet metal ends are ductile, and the weld stresses were compared to the stresses allowed by the ASME Boiler and Pressure Vessel Code, Section III, Subsection NE; the critical weld has a margin of safety of $12 \%$.

The lid bolts were evaluated under an internal pressurization of 2.2 psi. This represents the pressure due to the normal low atmospheric pressure for the Hanford site combined with the temperature-caused pressure rise inside the box. Assuming the bolts are uniformly loaded, they will have a stress of 15,670 psi when prying is considered. ASME Section II subsection D allows 20,200 psi in SA-449 bolts, which are equivalent to the $\mathrm{SAE}$ grade 5 bolts the package is assumed to use. 
HNF-2761, Rev. 0

ENGINEERING SAFETY EVALUATION

\begin{tabular}{|c|c|}
\hline PNNL HEPA BOX STRUCTURAL ANALYSIS & Page_2 2 of -5 \\
\hline WM.W SMYTH W & Date 1 June 98 \\
\hline Checker: $\quad$ S.S. SHIRAGA & Date 1 June 98 \\
\hline Section Chief: $\quad$ S. S, SHIRAGA & Date 1 June 98 \\
\hline
\end{tabular}

\subsection{EVALUATION}

Inertial loading of contents on box end wall

Investigate the effect of a $2.3 \mathrm{~g}$ longitudinal acceleration. The box is transported with the long axis parallel to the direction tra vel and the inner box and contents will bear on one end of the box. Should one of the 3 welds that joir the end to the sides fail, the other 2 welds will also fail due to prying and the inner box will no longer be confined. The bottom weld is the most heavily loaded for 2 reasons. The inner box's center of mass is low, and the outer box's sides will deform, relieving the load from the vertical welds and concentrate the stiff inner box's weight on the bottom seam.

The seam welds are shown as a $1 / 8$ in groove weld on the exterior of a comer. Since the material is 12 gage (.1046 in thick), it will be treated as a fillet weld with a leg of .105 in.

ASTM A-569 is not an ASME material. It is similar to AISI 1015 mild steel, which bas a listed strenth of $50 \mathrm{ksi}$ and a yield of $27.5 \mathrm{ksi}$. (ASM, 1982, Engineering Properties of Steel,Philip D. Harvey ed, American Society for Metals, Metals Park, Oh.). ASME section II, subsection. Using the ASME basis for allowable stress in appendix 1, Part D of section $\Pi$, the design strength is the smaller of $1 / 4$ of the tensile strength or $2 / 3$ of yield. Similar ASME materials have constant tensile strength up to $600^{\circ} \mathrm{F}$

$$
\begin{array}{ll}
\mathrm{Sm}:=\left(50000 \cdot \frac{\mathrm{psi}}{4}\right) \quad \operatorname{Sm}=12500 \text { psi } & \text { below } 600^{\circ} \mathrm{F} \\
\text { using ASME section III, subsection NE } & \text { Smc }:=1.1 \cdot \mathrm{Sm}
\end{array}
$$

$$
\mathrm{Smc}=13750 \cdot \mathrm{psi} \quad \text { basic allowable stress }
$$

Using ASME efficiency for a fillet weld in section III, subsection NE 3356, the weld strength is

$$
\mathrm{F}:=.55 \cdot .105 \cdot \mathrm{in} \cdot 707 \cdot 50 \cdot \mathrm{in} \cdot \mathrm{Smc} \quad \mathrm{F}=28070 \cdot \mathrm{lbf}
$$

Use the total package weight of $10,907 \mathrm{lb}: \quad$ Wt $:=10907 \cdot \mathrm{lbf}$

In order to retain the inner box and contents, the minimum weld strength must be

$$
2.3 \cdot \text { Wt } ~ \text { a } 25086 \cdot \mathrm{lbf}
$$

The end is adequate, with minimum margin of safety :

$$
\frac{F}{2.3 \cdot W t}-1=0.119
$$


HNF-2761, Rev. 0

ENGINEERING SAFETY EVALUATION

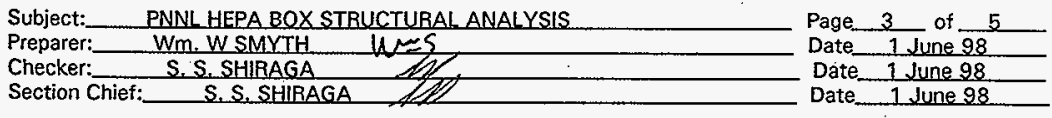

Check the average side wall stress in the box due to $2.3 \mathrm{Wt}$ bearing on an end wall. This is a primary membrane stress and must be less than $\mathrm{Sm}$

$$
\frac{2.3 \cdot \mathrm{Wt}}{2 \cdot 50 \cdot \mathrm{ir} \cdot 105 \cdot \mathrm{in}}=2389 \mathrm{opsi} \quad \text { margin of safety: } \quad \frac{\mathrm{Smc}}{2389 \cdot \mathrm{psi}}-1=4.756
$$

There is adequate margin for the bottom seam weld of an end wall to resist inertial forces due to an acceleration of $2.3 \mathrm{~g}$.

Calculate the bolt loading due to internal pressure.

The internal pressure rise due to atmospheric pressure decrease is $0.15 \mathrm{psi}$, and due to temperature rise is $2.0 \mathrm{lb}$. Use $2.2 \mathrm{psig}$ pressure to find the bolt loads. There are 18 bolts:

3/8-16 SAE grade 5 .

bolt force:

$$
\mathrm{F}:=\frac{2.2 \cdot \mathrm{psi} \cdot 100 \cdot \mathrm{in} \cdot 50 \cdot \text { in }}{18} \quad \mathrm{~F}=611-\mathrm{lbf}
$$

The bolts are in flanges made from 1.5 in by 1.5 in by .25 in angles, .75 in from the outside of the angle. The load comes from the back of the angle where it is welded to the sides of the box. Considering the angle to be stiff, the boit prying will double the force in the bolts.

$$
\mathrm{Fp}:=\frac{1.5 \cdot \mathrm{in}}{.75 \cdot \mathrm{in}} \cdot \mathrm{F} \quad \mathrm{Fp}=1222 \mathrm{olbf}
$$

A $3 / 16$ in bolt has a tensile area of $.0775 \mathrm{sq}$ in (Parmley, Standard Handbook of Fastening and Joining, $\mathrm{p}$ 1-31), so the tensile stress is :

$$
f:=\frac{F p}{.0775 \cdot \text { in }^{2}} \quad f=15771 \text { opsi }
$$

SAE Grade 5 bolts are equivalent to ASTM 449, medium carbon quenched and tempered steel. Compare the calculated stress with that allowed by ASME section II, Part D, table 3, for SA-449 bolts: 20.2 ksi below 650 $\operatorname{deg} \mathbf{F}$.

$$
\text { margin of safety is: } \quad \frac{20200 \cdot p s i}{f}-1=0.281
$$


HNF-2761, Rev. 0

ENGINEERING SAFETY EVALUATION

Subject: PNNL HEPA BOX STRUCTURAL ANALYSIS

Preparer:
Checker: Wm.W SMYTH
Section Chief: S.S. SHIRAGA
S.S. SHIRAGA

Page 4 of $\frac{5}{5}$

Date 1_June 98

Date 1. June 98

Date 1 June 98

\section{Vibration}

The ANSI standard for vibration loading for an $11,000 \mathrm{lb}$ package is a force with an RMS of $420 \mathrm{lb}$, at a frequence of $2 \mathrm{~Hz}$. The load is to be multiplied by 2.3 . Find the total force, the force per bolt, and the bolt stress caused by this loading, assuming that the load is entirely due to the lid:

$$
\begin{array}{ll}
\text { total force: } & 420 \cdot \mathrm{lbf} \cdot 2.3=966 \mathrm{dbf} \\
\text { force per bolt: } & \frac{420 \cdot \mathrm{lbf} \cdot 2.3}{18}=53.7 \mathrm{dlbf}
\end{array}
$$

increase this for prying as before, and combine with the force due to pressure:

$$
\begin{aligned}
& \frac{1.5}{.75} \cdot 53.7 \cdot \mathrm{lbf}+\mathrm{Fp}=1330 \mathrm{olbf} \\
& \text { total bolt stress: } \quad \frac{1330 \cdot \mathrm{lbf}}{.0775 \cdot \mathrm{in}^{2}}=17161 \cdot \mathrm{psi} \\
& \text { margin of safety is: } \quad \frac{20200 \cdot \mathrm{psi}}{17171 \cdot \mathrm{psi}}-1=0.176
\end{aligned}
$$

Penetration

Determine whether 12 gage steel will resist penetration by a $3.2 \mathrm{~cm}$ diameter rod with a rounded end, weighing $6 \mathrm{~kg}$. Use the Ballistic Research formula as presented in the Bechtel Topical report BC-TOP-9A to find the thickness of mild steel that will resist penetration. Assume a contact diameter of 692 in, based on a $1.25^{\prime \prime}$ round bar penetrating the thickness of the sheet $0.1046^{\prime \prime}$ as shown in the geometry below. If the thickness calculated is less than $0.1046^{\prime \prime}$, then the 12 gage material will resist penetration. 
HNF-2761, Rev. 0

\author{
ENGINEERING SAFETY EVALUATION
}

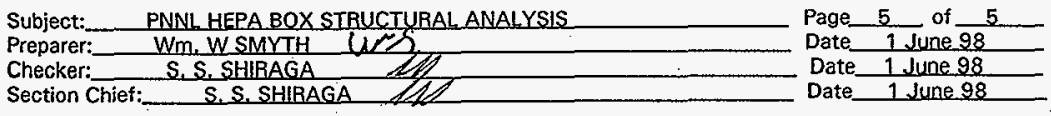

$\mathrm{T}:=\frac{\left[\frac{\left(.411 \cdot 14.5^{2}\right)}{2}\right]^{667}}{672 \cdot .692} \quad \begin{aligned} & \text { thickness, inches, that the round-tip bar will } \\ & \text { penetrate. The topical report suggests using } \\ & 1.25^{*} \mathrm{~T}\end{aligned}$

$\mathrm{T}=0.027 \quad 1.25 \cdot \mathrm{T}=0.033$

Since 12 gage material $>.033^{\prime \prime}$ thick, it will not be penetrated by the test bar.

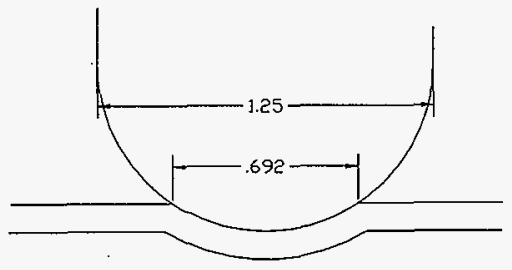


HNF-2761, Rev. 0

ENGINEERING SAFETY EVALUATION

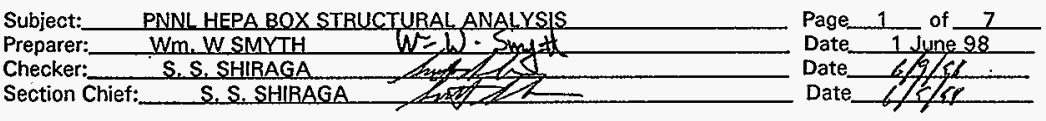

\subsection{OBJECTIVE}

Find the effects of internal and external pressure on the box.

\subsection{REFERENCES}

SRC, 1996: drawings for model 165-12-10 box by S. C. S. Incorporated, rev A, 1996

ASM, 1982: $\quad$ Engineering Properties of Steel, American Society for Metals, Metals Park, Ohio, 1982.

Roark, 1982: Formulas for Stress and Strain, Sth edition, Raymond J. Roark and Warren C. Young, McGraw-Hill, New York, 1982

ASME, 1992: ASME Boiler and Pressure Vessel Code, Section II, Subsection D, and Section III, Subsection NE, American Society of Mechanical Engineers, NY, 1992

AISC, 1980: Manual of Steel Construction, 8th ed, American Institute of Steel Construction, Chicago, IlL, 1980

Timoshenko, 1959: Theory of Plates and Shells, Temoshenko and Woinowsky-Krieger, second edition, McGraw-Hill, NY, 1959

\subsection{ASSUMPTIONS, RESULTS, AND CONCLUSIONS}

The HEPA box is evaluated for increased internal pressure using ASME criteria for metal containments. The internal pressure is due to increased temperature in the sealed box and decreased atmospheric pressure. The temperature-induced pressure calculated in section B8 of this SEP is 2.0 psi and the atmospheric pressure drop is 0.15 psi. A pressure difference of 2.2 psi was considered in this analysis.

The bottom, front, and back of the box are stiffened by channels or angles while the sides are stiffened by the flange angles. The maximum stresses will occur in the top, which is an unstiffened 100 in $\times 50$ in sheet. The sheet is too thin to use standard tabulated plate bending methods, so a large-deflection membrane approximation was used. The top was evaluated as a simply supported infinitely long plate with edges that are able to displace under the membrane stresses in the box top. The results were that the plate and weld stresses are within those allowabled for ASME section III, subsection NE, service level A service. 
HNF-2761, Rev. 0

\section{ENGINEERING SAFETY EVALUATION}

Subject: $\quad$ PNNL HEPA BOX STRUCTURAL ANALYSIS
Preparer: $\quad$ Wm. W SMYTH
Checker:
Section Chief: $\frac{\text { S. SHIRAGA }}{\text { S.S. SHIRAGA }}$

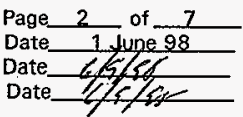

\subsection{EVALUATION}

ASTM A-569 is not an ASME material. It is similar to AISI 1015, which has a listed yield strength of yield of $27.5 \mathrm{ksi}$ and tensile strength of $50 \mathrm{ksi}$. (ASM, 1982, Engineering Properties of Steel,Philip D. Harvey ed, American Society for Metals, Metals Park, Oh.). Using the ASME basis for allowable stress in appendix 1 , Part D of section II, the design strength is the smaller of $1 / 4$ of the tensile strength or $2 / 3$ of yield.

$$
\begin{gathered}
\text { Sy }:=27500 \cdot \mathrm{psi} \quad \mathrm{Su}:=50000 \cdot \mathrm{psi} \\
\mathrm{Sm}:=\left(50000 \cdot \frac{\mathrm{psi}}{4}\right) \quad \frac{2 \cdot \mathrm{Sy}}{3}=18333 \circ \mathrm{psi} \quad \mathrm{Sm}=12500 \circ \mathrm{psi} \\
\text { using ASME section III, subsection NE } \quad \text { Smc }:=1.1 \cdot \mathrm{Sm} \\
\text { Smc }=13750 \cdot \mathrm{psi} \quad \begin{array}{l}
\text { basic allowable stress for metal } \\
\text { containments - use as the allowable } \\
\text { for this calculation. }
\end{array}
\end{gathered}
$$


HNF-2761, Rev. 0

\section{ENGINEERING SAFETY EVALUATION}

Subject:_ PNNL HEPA BOX STRUCTURAL ANALYSIS

Preparer:

Wm. W SMYTH

Checker:

S. S. SHIRAGA

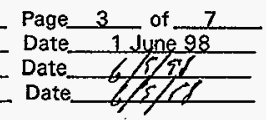

Section Chief:

S.S. SHIRAGA

$u=$

de

12

Use Timoshenko \& Woinowsky-Krieger, Theory of Plates and Shells. In the section on large deflection of rectangular plates, it states ( $p$ 422) that for aspect ratios of $>3 / 2$, the results of the chapter on infinitely long plates can be used.

$$
\begin{array}{ll}
\mathrm{E}:=29 \cdot 10^{6} \cdot \mathrm{psi} & \text { modulus of elasticity for carbon steel } \\
\mathrm{l}:=58 \cdot \mathrm{in} & \text { width of infinitely long box lid } \\
\mathrm{v}:=.3 & \quad \text { Poisson's ratio for carbon steel } \\
\mathrm{h}:=.1046 \cdot \mathrm{in} & \quad \text { thickness of steel sheet } \\
\mathrm{q}:=2.2 \cdot \mathrm{psi} & \begin{array}{l}
\text { maximum internal pressure due to temperature and } \\
\text { atmospheric pressure change }
\end{array}
\end{array}
$$

$$
D:=\frac{E \cdot h^{3}}{\left(1-v^{2}\right) \cdot 12} \quad D=3039 \cdot 1 \mathrm{bFin} \quad \text { plate stiffness }
$$


HNF-2761, Rev. 0

\section{ENGINEERING SAFETY EVALUATION}

Subject: PNNL HEPA BOX STRUCTURAL ANALYSIS

Preparer: Wm. W SMYTH

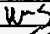

The very thin sheet will offer almost no bending and the top sheet will deflect with very low resistence and the simply supported plate formulation can be used:

$$
U 0(u):=\left[\left(\frac{135}{16} \cdot \frac{\tanh (u)}{u^{9}}+\frac{27}{16} \cdot \frac{\tanh (u)^{2}}{u^{8}}\right)-\left(\frac{135}{16 \cdot u^{8}}\right)\right]+\frac{9}{8 \cdot u^{6}} \quad \begin{aligned}
& \text { Equation (8) on page } \\
& 8 \text {, Timoshenko }
\end{aligned}
$$

Additionally, the edge angle will offer minimal bending restraint for the membrane forces and the plate edges not be rigidly fixed at their edges. Correct for edge displacement using equation 22 on page 20. Calculate the simple beam bending deflection for the 2 horizontal angle legs, $100^{\prime \prime}$ long. The angles are $1.25^{\prime \prime} \times 1.25^{\prime \prime} \times .25^{\prime \prime}$

The beam load is the difference between the shear from the sides of the box, 58" high, and the membrane stress in the top: assume a stress of $612 \mathrm{psi}$ in the box top and calculate the shear in the side from the pressure. This is a reasonable assumption to account for some edge stiffness. So long as the calculated stress is greater, the results will be conservative:

$$
\text { Fside }:=2.2 \cdot \mathrm{psi} \cdot \frac{58 \cdot \text { in }}{2} \quad \text { Ftop }:=612 \cdot \mathrm{psi} \cdot \mathrm{h} \quad \text { Ftop }=64.02 \frac{\mathrm{lbf}}{\mathrm{in}}
$$

bending force in the

beam is

$$
\begin{gathered}
\text { fbeam }:=\text { Ftop }- \text { Fside } \\
\text { fbeam }=0.215 \frac{\mathrm{lbf}}{\text { in }}
\end{gathered}
$$

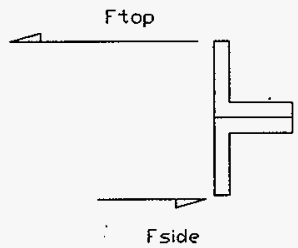


HNF-2761, Rev. 0

ENGINEERING SAFETY EVALUATION

Subject:

PNNL HEPA BOX STRUCTURAL ANALYSIS

Preparer:

Wm. W SMYTH

itise

Checker:

S. S. SHIRAGA

Page 5 of 7

Section Chief:

S. S. SHIRAGA

Date

Date.

Date

Calculate the bending deflection for a simply supported beam with a triangular

load: fbeam in the center and 0 at the ends (AISC p2-114, case 3). The

basis for a stress estimate of 612 psi was simply to produce a reasonable

beam deflection.

moment of inertia of 2 angles: $\quad$ Ibm $:=\frac{2 \cdot .25 \cdot \text { in } \cdot(1.25 \cdot \text { in })^{3}}{12}$

Wheam $\quad:=.5 \cdot 100 \cdot$ in fbeam $\quad \Delta:=\frac{\text { Wbeam } \cdot(100 \cdot \text { in })^{3}}{60 \cdot \mathrm{E} \cdot \mathrm{Ibm}} \quad \Delta=0.076 \cdot$ in

$$
F(u):=\left[\frac{E \cdot h^{4}}{\left(1-v^{2}\right) \cdot q \cdot l^{4}}\right]^{2}-\frac{u^{2}}{u^{2}+3 \cdot \frac{1 \cdot \Delta}{h^{2}}} \cdot U 0(u)
$$

This is unstable and iteration must be used to force convergence.

$z:=13.52$

$$
u:=\operatorname{root}(F(z), z) \quad u=13.520
$$

$S:=4 \cdot u^{2} \cdot \frac{D}{1^{2}}$

$S=660.591 \quad \frac{\mathrm{lbf}}{\text { in }}$

force at edge of plate

$$
\text { on }:=\frac{S}{h} \quad \text { om }=6315 \text { opsi } \quad \begin{aligned}
& \text { membrane stress, at edge and } \\
& \text { center }
\end{aligned}
$$

This is greater than used to calculate the beam deflection: the actual stress will be less than calculated.

$$
\begin{gathered}
\psi 0:=\frac{1-\operatorname{sech}(u)}{\frac{u^{2}}{2}} \quad \begin{array}{l}
\text { bending moment function; (e) on } \\
p 9, \text { of Timoshenko }
\end{array} \quad \psi 0=0.0109 \\
\infty:=.75 \cdot q \cdot\left(\frac{1}{h}\right)^{2} \cdot \psi 0 \quad \infty=5551-p s i \quad \text { bending stress at center of plate } \\
\text { omax }:=\infty+\infty m \quad \text { omax }=11866 \text { opsi }
\end{gathered}
$$


HNF-2761, Rev. 0

ENGINEERING SAFETY EVALUATION

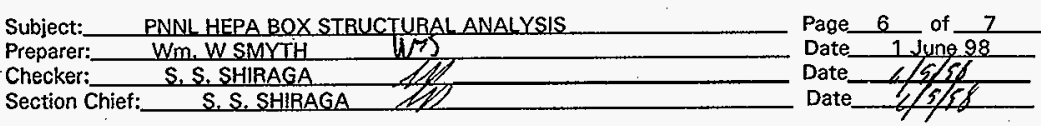

Compare the membrane stress to the allowable primary membrane stress:

margin of safety $\quad \frac{\mathrm{Smc}}{\mathrm{am}}-1=1.177$

Compare the total stress to the allowable primary membrane + bending:

margin of safety $\quad \frac{1.5 \cdot \mathrm{Smc}}{\text { omax }}-1=0.738$

deflection solution, eq (12) on $\mathrm{p} 11$ of Timoshenko

$f(u):=\frac{\operatorname{sech}(u)-1+\frac{u^{2}}{2}}{5 \cdot \frac{u^{4}}{24}} \quad$ mmax $:=\frac{5 \cdot q \cdot 1^{4} \cdot f(u)}{384 \cdot D} \quad$ wmax $=1.385 \cdot \mathrm{in}$

Check fillet welds under diaphram loading due to 2.2 psi pressure.

The lid is secured with 2 welds, both noted as $1 / 8$ " fillets. The upper weld is at the point where the lid is bent, the lower is where the lid sheet is cut. Th upper weld will provide all restraint to the lid reactions. The upper weld is continuous; the lower is 1.5 in per 12 in.

weld area
inch of weld: $\quad$ Awu $:=0.707 \cdot .1046 \cdot$ in $\quad$ Awu $=0.07395 \cdot \frac{\mathrm{in}^{2}}{\text { in }}$

use the sheet thickness as the weld size instead of the $1 / 8^{\text {th }}$ size since the sheet thickness is the limiting size of the smaller weld leg. 
HNF-2761, Rev. 0

\section{ENGINEERING SAFETY EVALUATION}

Subject:_PNNL HEPA BOX STRUCTURAL ANALYSIS

Preparer:

WM. W SMVTH W W

Page 7 of 7

Checker:

S. S. SHIRAGA

Section Chief:

S.S. SHIRAGA

Date

Date.

Date

In-plane weld force is the plate

diaphram stress multiplied by the

plate thickness:

$$
\mathrm{Fx}:=\mathrm{S}
$$

$\mathrm{Fx}=661 \stackrel{\mathrm{lbf}}{\frac{\mathrm{in}}{\mathrm{in}}}$

vertical forces

on weld:

$$
\mathrm{Fz}:=\frac{2.2 \cdot \mathrm{psi} \cdot 100 \cdot \mathrm{in} \cdot 58 \cdot \mathrm{in}}{2 \cdot 200 \cdot \mathrm{in}}
$$

$\mathrm{Fz}=31.9 \cdot \stackrel{\mathrm{lbf}}{\mathrm{in}}$

upper weld stress:

$$
\begin{aligned}
& \text { Ftot }:=\sqrt{\mathrm{Fz}^{2}+\mathrm{Fx}^{2}} \quad \text { Ftot }=661 \frac{\mathrm{lbf}}{\text { in }} \\
& \frac{\text { Ftot }}{\text { Awu }}=8943 \text { opsi }
\end{aligned}
$$

Combining the ASME weld efficiency for a fillet weld under Section III,

Subsection NE, and the 1.5 increase for local membrane stresses for level A service, the strength of the weld is

$$
\mathrm{F}:=1.5 \cdot 0.55 \cdot \mathrm{Smc} \quad \mathrm{F}=11344-\mathrm{psi}
$$

There is a positive margin for the weld of against ASME stress criteria for level A service stresses:

$$
\frac{F}{\frac{\text { Ftot }}{\text { Awu }}}-1=0.268
$$




\subsection{THERMAL EVALUATION}

\subsection{INTRODUCTION}

The box used for this shipment was purchased as a strong-tight package for LSA material under the rules of 49 CFR 173.427 and is described by the drawings for Model 165-12-10 in Part A, Section 10.3. The box is used to transport HEPA filters from the 300 Area to the 200 Area burial grounds. This evaluation demonstrates that the package meets the thermal criteria for safe transportation on the Hanford Site.

\subsection{THERMAL EVALUATION}

\subsubsection{Package Description}

The box described in the drawings in Part A, Section 10.3, is $2.58 \mathrm{~m}$ (101.5 in.) long by $1.33 \mathrm{~m}$ (52.5 in.) wide by $1.64 \mathrm{~m}$ (64.5 in.) high. It is fabricated from carbon steel sheet $2.3 \mathrm{~mm}$ thick ( 0.1046 in., 12 gage). The box contains HEPA filters that are inside a carbon steel inner box that provides shielding. There are four channels on the bottom of the box that form forklift pockets and enable air to circulate under the box.

The box is sealed with a flat EPDM gasket $25 \mathrm{~mm}(1.0 \mathrm{in.})$ wide by $9 \mathrm{~mm}(3 / \mathrm{sin}$.$) thick glued$ to the underside of the lid. The seal is compressed approximately $1.6 \mathrm{~mm}(1 / 16 \mathrm{in}$.) against an extension to the boxes sides when the flanges are bolted.

\subsection{NORMAL TRANSFER CONDITIONS THERMAL EVALUATION}

\subsubsection{Conditions To Be Evaluated}

Heating of the box is evaluated for the following Hanford Site conditions of solar insolation and ambient temperature: during a 12-hour period, the package receives $54 \mathrm{cal} / \mathrm{cm}^{2} / \mathrm{h}$ $\left(2,386 \mathrm{Btu} / \mathrm{ft}^{2} / \mathrm{h}\right)$ on horizontal surfaces and $13.5 \mathrm{cal} / \mathrm{cm}^{2} / \mathrm{h}\left(597 \mathrm{Btu} / \mathrm{ft}^{2} / \mathrm{h}\right)$ on vertical surfaces, and the maximum ambient temperature is $115^{\circ} \mathrm{F}$. Heating by the contents is given in Part $\mathrm{B}$, Section 2.0, of this SEP as $0.17 \mathrm{~W}(0.68 \mathrm{Btu} / \mathrm{h})$. For cold conditions, the ambient temperature is $-33^{\circ} \mathrm{C}\left(-27^{\circ} \mathrm{F}\right)$, and there is no insolation.

\subsubsection{Acceptance Criteria}

No accessible part of the package can be above $85^{\circ} \mathrm{C}\left(185^{\circ} \mathrm{F}\right)$ when the package is in still air at $46{ }^{\circ} \mathrm{C}\left(115^{\circ} \mathrm{F}\right)$ and in the shade for an exclusive-use package, or $50^{\circ} \mathrm{C}\left(122^{\circ} \mathrm{F}\right)$ for nonexclusive use. Neither cold conditions nor hot conditions combined with internal heating and insolation specified in $10 \mathrm{CFR} 71$ for normal conditions can cause a release of radioactive materials.

\subsubsection{Thermal Evaluation and Conclusions}

A thermal evaluation in the appendix (Part B, Section 8.5) demonstrates that the package will meet the thermal acceptance criteria for normal conditions of transportation. 
The evaluation found that without insolation, the temperature will not rise significantly above the ambient temperature of $46^{\circ} \mathrm{C}\left(115^{\circ} \mathrm{F}\right)$, so both the exclusive-use and non-exclusive-use criteria are met. The evaluation found that with the insolation specified in 10 CFR 71 for normal conditions of transport, combined with internal heating, the box's exterior surface temperature will be $64^{\circ} \mathrm{C}\left(147^{\circ} \mathrm{F}\right)$. The EPDM seal has a service temperature range of $-54^{\circ} \mathrm{C}\left(-65^{\circ} \mathrm{F}\right)$ to $149^{\circ} \mathrm{C}$ $\left(+300^{\circ} \mathrm{F}\right)$, so it will not be adversely affected by the temperature (Parker 1992). Part $\mathrm{B}$,

Section 7.0, of this SEP demonstrates that the steel components of the package are not adversely affected by either the cold conditions or the hot conditions considered in this evaluation. Part $\mathrm{B}_{\text {, }}$ Section 7.0, of this SEP additionally considers the pressure rise caused by the hot conditions and demonstrates that the package will not fail due to the pressure.

\subsection{REFERENCES}

10 CFR 71, "Packaging and Transportation of Radioactive Material," Code of Federal Regulations, as amended.

49 CFR 173, "Shippers--General Requirements for Shipments and Packagings," Code of Federal Regulations, as amended.

Parker, 1992, Parker O-Ring Handbook, Parker Seals Group, O-Ring Division, Lexington Kentucky. 


\subsection{APPENDIX: THERMAL ANALYSIS}

\section{ENGINEERING SAFETY EVALUATION}

Subject:
Preparer: PNNL HEPA BOX THERMALANALYSIS
Checker: $\frac{\text { WM. W SMYTH }}{\text { S.S. SHIRAGA }}$
Section Chief:

\subsection{OBJECTIVE}

Determine the maximum temperature of the exterior surface of the box during on-site transportation normal conditions. Since the box is $2.3 \mathrm{~mm}$ thick carbon steel and the internal heat is very small compared with the external heating heat source, the surface temperature can be used as the temperature within the interior of the box and the contents.

\subsection{REFERENCES}

Irwin, 1996: WHC-SD-TP-RPT-00S, rev 1, Thermal Analysis Methods for Safety Analysis Reports for Packaging, John J. Irwin, Jan. 1996, Westinghouse Hanford Company, Richland, WA.

SRC, 1996: drawings for model 165-12-10 box by S. C. S. Incorporated, rev A, 1996.

Fadef, 1992 Environmental Conditions for On-Site Hazardous Materials Packages, WHC-SD-RPT-004 rev O, Fadef, J. G., Westinghouse Hanford Company, Richland WA, 1992.

\subsection{ASSUMPTIONS, RESULTS, AND CONCLUSIONS}

For on-site transportation, packages are evaluated using $2386 \mathrm{BTU} / \mathrm{t}^{2}$ on the horizontal box top and 597 $\mathrm{BTU} / \mathrm{ft}^{2}$ on 2 sides, and an ambient temperature of $115^{\circ} \mathrm{F}$ (Fadef, 1992). When combined with heat generation of the contents, $0.2 \mathrm{~W}$, this evaluation found the maximum temperature of the box's surface to be $64^{\circ} \mathrm{C}$ ( 147 $\left.{ }^{\circ} \mathrm{F}\right)$. Without insolation the surface of the box will remain at the ambient temperature.

The top and 2 sides of the box were assumed to be fully exposed to insolation, and 0.85 was used for the emmisivity and solar absorbtivity (Irwin, 1996). The box top, sides, and bottom are convection surfaces with values justified for conservative transportation-specific conditions (Irwin, 1996).

Assuming that the box was sealed at a temperature of $73^{\circ} \mathrm{F}$ and an atmospheric pressure of $14.7 \mathrm{psia}$, and that the gasket remains firmly seated even when the lid distorts, the inside of the box will be pressurized to $2.0 \mathrm{psi}$ when the contents are heated to $147^{\circ} \mathrm{F}$ due to temperature. 


\section{ENGINEERING SAFETY EVALUATION}

Subject:

Preparer:

Checker:

Section Chief:
PNNL HEPABOX THERMAL ANALYSIS

Wm. W SMYTH

S. S. SHIRAGA

S. S. SHIRAGA
Page_ 2 of $\quad 4$ Date 27 MAY 98 Date Date.

Len $:=100$-in Width $:=50$-in $\quad H t:=58 \cdot$ in $\quad \begin{aligned} & \text { Use inside dimension from } S C S \text { drawing } \\ & \text { for model } 165-12-10 \text { box. }\end{aligned}$

$\mathrm{Qi}:=0.2 \cdot$ watt $\quad$ Heat source from section $\mathrm{B} 2$

As1 := Len.Ht As2 := Width.Ht Calculate the 2 side areas and the area of the box top Atop := Len-Width

$\mathrm{Ta}:=(460+115) \cdot \mathrm{R}$

Using Fadeff, 1992, define the atmospheric temperature using the maximum Hanford of $115^{\circ} \mathrm{F}$.

$\varepsilon:=.85$ enamel paint emmisivity and solar absorbtivity [Irwin 1996] for non-white color at $100^{\circ} \mathrm{F}$. The box is light gray.

For on-site transportation, the 12 hour insolation values are $2386 \mathrm{BTU} / \mathrm{sq} \mathrm{ft}$ for flat horizontal surfaces and $597 \mathrm{BTU} / \mathrm{sq}$ ft for non-horizontal surfaces (Fadeff, 1992). Assume top and 2 sides are exposed.

$$
\begin{aligned}
& \text { Qs1 }:=\frac{2386}{12 \cdot h r} \cdot \frac{\mathrm{BTU}}{\mathrm{ft}^{2}} \quad \text { top horizontal surface } \\
& \text { Qs2 }:=\frac{597}{12 \cdot \mathrm{hr}} \cdot \frac{\mathrm{BTU}}{\mathrm{ft}^{2}} \quad \text { vertical sides } \\
& \text { Qsol }:=\varepsilon \cdot((Q s 1 \cdot A t o p)+(\text { Asl }+ \text { As2 }) \cdot Q s 2) \\
& \text { Qsol }=8423 \cdot \frac{\mathrm{BTU}}{\mathrm{hr}} \quad \text { Qtot }:=\mathrm{Qsol}+\mathrm{Qi} \quad \text { Qtot }=8424 \cdot \frac{\mathrm{BTU}}{\mathrm{hr}} \\
& \sigma:=.1714 \cdot 10^{-8} \cdot \frac{\mathrm{BTU}}{\mathrm{hr} \cdot \mathrm{ft}^{2} \cdot \mathrm{R}^{4}} \quad \text { Stefan-Boltzman constant } \\
& \text { Qr }(\mathrm{T}):=\sigma \cdot \varepsilon \cdot(\text { Atop }+2 \cdot A s 1+2 \cdot A s 2) \cdot\left(\mathrm{T}^{4}-\mathrm{Ta}^{4}\right) \quad \begin{array}{l}
\text { Heat transfer at temperature } \mathrm{T} \text { due to } \\
\text { radiation from top and } 4 \text { sides, view }
\end{array}
\end{aligned}
$$


Subject: PNNL HEPA BOX THERMAL ANALYSIS

Preparer:

WM. W SMYTH
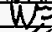

S. S. SHIRAGA

Checker:

S. S. SHIRAGA

Page_ 3 of 4

Section Chief:

S. S. SHIRAGA

Date

Date

Date

Convection film coefficients for vertical and horizontal surfaces [lrwin, 1996]

$$
\begin{aligned}
& \mathrm{h} 1(\mathrm{~T}):=.29 \cdot\left(\frac{\mathrm{T}-\mathrm{Ta}}{\mathrm{Ht}}\right)^{.25} \cdot \frac{\mathrm{BTU}}{\mathrm{hr} \cdot \mathrm{ft}^{1.75} \cdot \mathrm{R}^{1.25}} \text { top - hot side up } \\
& \mathrm{h} 2(\mathrm{~T}):=.27 \cdot\left(\frac{\mathrm{T}-\mathrm{Ta}}{\mathrm{Width}}\right)^{.25} \cdot \frac{\mathrm{BTU}}{\mathrm{hr} \cdot \mathrm{At}^{1.75} \cdot \mathrm{R}^{1.25}} \quad \text { sides } \\
& \mathrm{h} 3(\mathrm{~T}):=0.12 \cdot\left(\frac{\mathrm{T}-\mathrm{Ta}}{\text { Width }}\right)^{.25} \cdot \frac{\mathrm{BTU}}{\mathrm{hr} \cdot \mathrm{ft}^{1.75} \cdot \mathrm{R}^{1.25}} \text { bottom - hot side down }
\end{aligned}
$$

Convection heat transfer at temperature $T$

$$
\mathrm{Qc}(\mathrm{T}):=((\mathrm{hl}(\mathrm{T}) \cdot(2 \cdot \mathrm{Asl}+2 \cdot \mathrm{As} 2))+\mathrm{h} 2(\mathrm{~T}) \cdot \mathrm{Atop}+\operatorname{Atop} \cdot \mathrm{h} 3(\mathrm{~T})) \cdot(\mathrm{T}-\mathrm{Ta})
$$

$T:=(116+460) \cdot R \quad$ initial value to start iteration $\quad F:=R$

$$
\text { Ts }:=\operatorname{root}(\mathrm{Qr}(T)+Q c(T)-Q t o t, T) \quad T s=606.7 \cdot R \quad T s-T a=32 . \mathrm{F}
$$

Ts - 460:Ra $147 \cdot \mathrm{F} \quad$ temperature of box surface

Calculate the pressure rise due to a uniform temperature of Ts within the box assuming it was loaded at room temperature, $73^{\circ} \mathrm{F}$, using the perfect gas law.

$$
\mathrm{p}:=\left[\frac{\mathrm{Ts}}{(460 \cdot \mathrm{R}+73 \cdot \mathrm{R})}-1\right] \cdot 1 \cdot \mathrm{atm} \quad \mathrm{p}=2.0 \mathrm{opsi}
$$


HNF-2761, Rev. 0

\section{ENGINEERING SAFETY EVALUATION}

Subject: PNNL HEPA BOX THERMALANALYSIS

Preparer:

Wm. W SMYTH

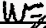

Page 4 of 4

Checker:

S. S. SHIRAGA

Date 27 MAY 98

Section Chief:

S. S. SHIRAGA

Date

Date

Calculate the package temperature and pressure without insolation:

$$
\begin{aligned}
& \text { Qtot }:=\mathrm{Qi} \quad \text { Qtota } 1 \cdot \frac{\mathrm{BTU}}{\mathrm{hr}} \quad \text { Total heat flux } \\
& \mathrm{T}:=(116+460) \cdot \mathrm{R} \quad \cdot \text { initial value to start iteration } \\
& \text { Ts }:=\operatorname{ropt}(\mathrm{Qr}(\mathrm{T})+\mathrm{Qc}(\mathrm{T})-\mathrm{Qtot}, \mathrm{T}) \quad \mathrm{Ts}=575 \cdot \mathrm{R} \quad \mathrm{Ts}-\mathrm{Ta}=4 \cdot 10^{-3} \cdot \mathrm{F}
\end{aligned}
$$

Ts $-460 \cdot R=115 \cdot F \quad$ Uniform temperature of box surface and interior.

Calculate the pressure rise due to a uniform temperature of Ts within the box assuming it was loaded at room temperature, $73^{\circ} \mathrm{F}$, using the perfect gas law.

$$
p:=\left[\frac{T s}{(460 \cdot R+73 \cdot R)}-1\right] \cdot 1 \cdot a t m \quad p=1.2 \cdot p s i
$$




\subsection{GAS GENERATION AND PRESSURE EVALUATION}

\subsection{INTRODUCTION}

A pressure and gas generation evaluation is performed to verify that the performance of the packaging system is not adversely affected during transport. Due to the composition of the contents of the box, a detailed analysis is not required.

\subsubsection{Assumptions}

It is assumed that the contents of the box do not include any organic materials or water that could result in the radiolytic generation of hydrogen gas. This assumption is supported by the known composition and use of the HEPA filters.

\subsubsection{Results}

The contents will not generate gases. The air inside the box may heat up due to insolation or an increase in ambient temperatures. The box should be inspected for evidence of this occurrence (e.g., significant bulging), and corrective actions should be taken before shipping the box.

\subsection{GAS GENERATION AND PACKAGE PRESSURE}

\subsubsection{Conditions To Be Evaluated}

The only conditions of concern are those resulting from elevated temperatures inside the box due to insolation and increased ambient temperatures. The estimated maximum pressure rise due to temperature increase is $13.8 \mathrm{kPa}(2.0 \mathrm{psi}$ ) (Part B, Section 8.0 ).

\subsubsection{Acceptance Criteria}

The acceptance criteria for the box are that the outer walls of the box do not exhibit significant deformation due to internal pressure increase.

\subsubsection{Engineering Analysis}

The increase in internal temperature from $23^{\circ} \mathrm{C}\left(73^{\circ} \mathrm{F}\right)$ to $64^{\circ} \mathrm{C}\left(147^{\circ} \mathrm{F}\right)$ will result in a potential pressure increase of $13.8 \mathrm{kPa}(2.02 \mathrm{psi})$. Because the condition of the gasket on the box is unknown, it is highly likely that the box is not airtight and the external and internal pressures will equalize. In case the box is sealed, it should be examined for evidence of pressurization before shipping. 
HNF-2761, Rev. 0

This page intentionally left blank.

B9-2 
HNF-2761, Rev. 0

\subsection{TIEDOWN EVALUATION}

\subsection{SYSTEM DESIGN}

The package shall weigh less than $5,450 \mathrm{~kg}(12,000 \mathrm{lb})$ and shall be secured in accordance with 49 CFR 393.100 , which requires that the tiedown system have a working strength of $2,730 \mathrm{~kg}(6,000 \mathrm{lb})$ in any direction. This can be accomplished by using two synthetic web straps side-side over the package, blocking around the bottom of the package along each long side, and side-to-side chains over the bottom reinforcing channel. Refer to Figures 1 and 2 in the appendix (Part B, Section 10.4). In lieu of blocking, the package may be placed on a commercially available rubberized load mat. If this option is used, the deck and the bottom of the package must be clean, dry, and free of oil and debris.

\subsection{ATTACHMENTS AND RATINGS}

The lifting bails on the box lid shall not be used to lift the package or to secure it to the vehicle.

The conveyance shafl have a capacity of $5,450 \mathrm{~kg}(12,000 \mathrm{lb})$ or greater for the footprint of the package and shall have a wooden deck $2.4 \mathrm{~m}(8 \mathrm{ft})$ wide and at least $7.62 \mathrm{~cm}(3.0 \mathrm{in}$.) thick. If a deck other than this is used, the shipper shall be responsible for designing the tiedown system to provide resistance to load shifting no less than that specified in 49 CFR 393.100.

The package shall be centered from side to side on the conveyance with its length in the direction of travel. Blocking capable of resisting a horizontal force of $2,730 \mathrm{~kg}(6,000 \mathrm{lb})$ shail be positioned on both sides of the box. The blocking shall consist of $2 \times 6$ lumber $10 \mathrm{ft}$ long, two per side, nailed through the $7.62 \mathrm{~cm}(3-i n$.$) thick deck of the vehicle. The blocking shall be fastened$ to the deck using $2050 \mathrm{~d}$ common nails (5.5 in. long, 0.244 in. diameter) every 6 in.; this requires 20 nails on each side of the package. As an alternative to blocking, the package may be set on a rubberized load mat to increase frictional resistance. To ensure maximum resistance to internal loading, the deck of the conveyance and bottom of the package must be clean, dry, and free of oil and debris. The load mat must have a surface area no less than the bottom of the entire box.

Two synthetic webs straps shall pass side to side over the package to provide vertical and tipping restraint. The straps shall have a working load limit of $1,360 \mathrm{~kg}(3,000 \mathrm{lb})$ or greater, and they shall be fastened to the sides of the deck at points capable of resisting a force of $1,360 \mathrm{~kg}$ $(3,000 \mathrm{lb})$. . All slack shall be removed.

One or two chains shall provide longitudinal restraint. The chain shal! have a working load limit of greater than $1,925 \mathrm{~kg}(4,243 \mathrm{lb})$.

\subsection{REFERENCE}

49 CFR 393, "Parts and Accessories Necessary for Safe Operation," Code of Federal Regulations, as amended. 


\subsection{APPENDIX: TIEDOWN ANALYSIS}

\section{ENGINEERING SAFETY EVALUATION}

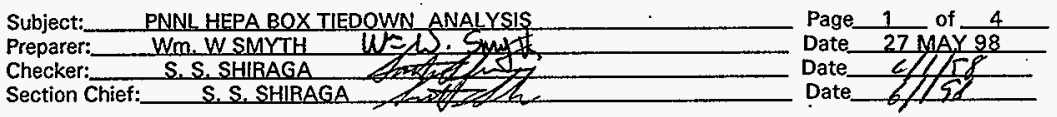

\subsection{OBJECTIVE}

Analyse the tiedown for the PNNL HEPA FILTER BOX according the the requirements of 49 CFR 193.100.

\subsection{REFERENCES}

SRC, 1996: drawings for model 165-12-10 box by S. C. S. Incorporated, rev A, 1996

49 CFR 393 Parts and Accessories Neccesary for Safe Operation, Cade of Federal Regulations, Department of Transportation, 1997.

UBC, 1988 Uniform Building Code and Uniform Building Code Standards, International Association of Building Code Officials, Whittier CA, 1988

\subsection{ASSUMPTIONS, RESULTS, AND CONCLUSIONS}

The PNNL HEPA FILTER BOX can be secured in compliance with the rules of 49 CFR 393 Subpart I (Protection Against Shifting or Falling Cargo) when the load is secured to its conveyence as specified in this appendix.

The tiedown system uses a combination of blocking, straps, and chains and will resist forces of over $1 / 2$ of the gross package weight in any direction. 


\section{ENGINEERING SAFETY EVALUATION}

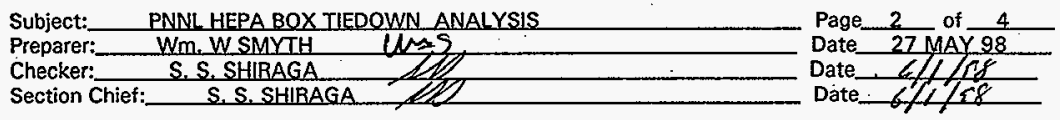

\subsection{EVALUATION}

Use 2 straps to provide vertical restraint. Conservatively, assume the straps make an angle of $45^{\circ}$ and calculate the tension in the 4 legs.

$$
\mathrm{T}:=\frac{.5 \cdot 12000 \cdot 1 \mathrm{bf}}{4 \cdot \cos (45 \cdot \mathrm{deg})} \quad \mathrm{T}=2121 \cdot \mathrm{lbf}
$$

Straps with a working load limit of $3000 \mathrm{lb}$ are adequate.

Blocking must provide a resistance to a $6000 \mathrm{lb}$ lateral force at its working stress limit.

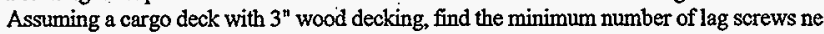
to fasten wood or steel blocking to the deck. Use Group III properties to allow any Oak, Douglas-Fir, or close-grained Redwood.

Provide 2 pieces of $2 \times 6$ secured to the deck on each side of the box ( 3 "total thickness). Use $50 \mathrm{~d}$ common nails ( 5.5 in long, $3 \mathrm{ga}$ ) through both pieces into the deck, giving 2.5 in penetration. UBC table 25-G shows an allowable load of 199 for 2.75 in penetration into Douglas Fir - Larch and section 2510 requires interpolation for smaller penetration. Impact loading allows the allowable load to be doubled.

$$
\begin{aligned}
& \text { Normal duration allowable load . } \quad P:=\frac{2.5}{2.75} \cdot 199 \cdot 1 \mathrm{bf} \\
& \text { for } 2^{n} \text { penetration } \\
& \text { Number of nails req'd: } \\
& \quad \frac{.5 \cdot 12000 \cdot 1 \mathrm{bf}}{2 \cdot P}=16.6
\end{aligned}
$$

Lateral load resistance can be provided using a two $10^{\prime}$ long $2 \times 6$ 's bearing on the 4 forklift riser chanels with nails every 6 inches ( 20 nails each side of the box.) 


Subject: $\quad$ PNNL HEPA BOX TIEDOWN ANALYSIS
Preparer: $\quad$ Wm. W SMYTH
Checker:
Section Chief: S. S. SHIBAGA
S.S. SHIRAGA
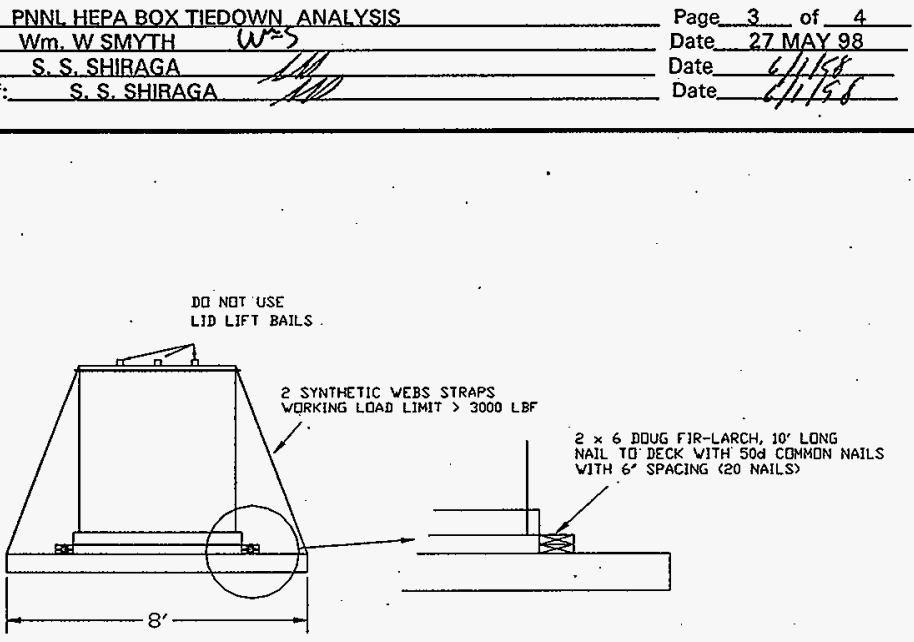

FIGURE 1

Longitudinal restraint can be provided by using chain or straps above the reinforcing channel. Assuming a 45 degree angle and 2 active legs resisting the load, the required strength is:

$$
\frac{.5 \cdot 12000 \cdot 1 \mathrm{bf}}{2 \cdot .707}=4243 \cdot \mathrm{lbf}
$$

$5 / 16$ in grade 7 transport chain provides a working strength of $4700 \mathrm{lbf}$.

The front chain is not required if the conveyance has a front end structure with a strength greater than $6,000 \mathrm{lbf}$ and the package can be placed in contact with the front end structure. The chain shall pass over the top of the reinforcing channel and be secured to 
HNF-2761, Rev. 0

t.

\section{ENGINEERING SAFETY EVALUATION}

Subject:_ PNNLHEPA BOX TIEDOWN ANALYSIS

Preparer:

Checker:

Wm. W SMYTH

S. S. SHIRAGA

Section Chief:

Page 4 of 4 Date 27MAY98

Date

Date
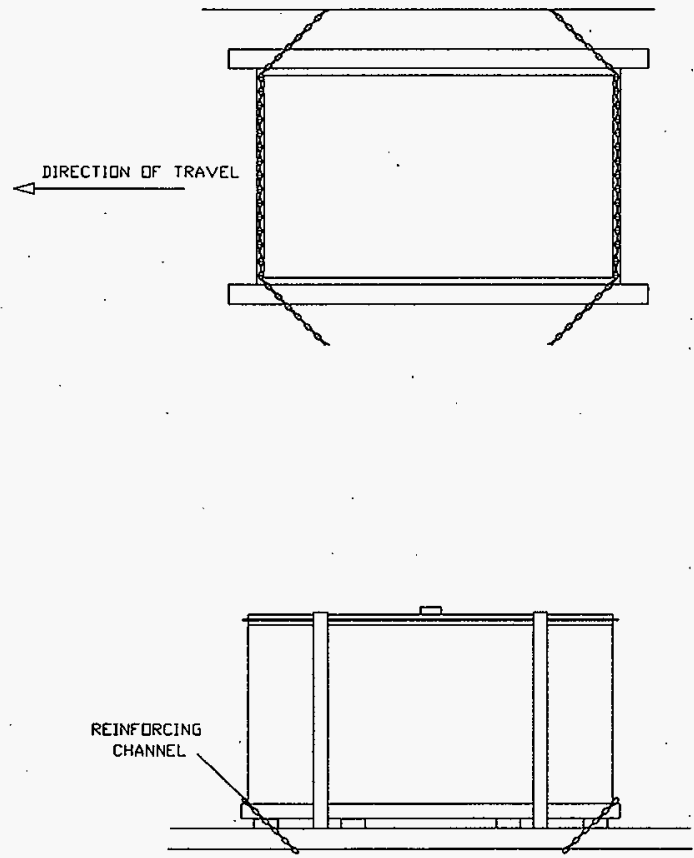


\section{DISTRIBUTION SHEET}

\begin{tabular}{|c|c|c|c|c|c|}
\hline \multirow{2}{*}{ Do } & \multirow{2}{*}{\multicolumn{3}{|c|}{$\begin{array}{l}\text { From } \\
\text { Packaging Engineering }\end{array}$}} & \multicolumn{2}{|c|}{ Page 1 of 1} \\
\hline & & & & \multicolumn{2}{|c|}{ Date July 14, 1998} \\
\hline \multicolumn{4}{|c|}{ Project Title/Work Order } & \multicolumn{2}{|c|}{ EDT No. N/A } \\
\hline \multicolumn{4}{|c|}{$\begin{array}{l}\text { Safety Evaluation for Packaging (Onsite) for the Pacific } \\
\text { Northwest National Laboratory HEPA Filter Box (HNF-2761, Rev. 0) }\end{array}$} & \multicolumn{2}{|c|}{ ECN No. 622375} \\
\hline Name & MSIN & $\begin{array}{c}\text { Text } \\
\text { With All } \\
\text { Attach. }\end{array}$ & Text Only & $\begin{array}{l}\text { Attach./ } \\
\text { Appendix } \\
\text { Only }\end{array}$ & $\begin{array}{l}\text { EDT/ECN } \\
\text { Only }\end{array}$ \\
\hline $\begin{array}{l}\text { R. L. Catlow } \\
\text { R. L. Clawson } \\
\text { P. C. Ferrel1 } \\
\text { J. G. Field } \\
\text { C. R. Hoover } \\
\text { J. C. McCoy } \\
\text { T. Romano } \\
\text { K. S. Webster } \\
\text { Document Processing Center } \\
\text { HNF-276I File } \\
\text { Work Control (D. Kelly) }\end{array}$ & $\begin{array}{l}P 7-75 \\
H 1-14 \\
H 1-15 \\
H 1-15 \\
H 1-15 \\
H 1-15 \\
H 1-15 \\
P 7-75 \\
A 3-94 \\
H 1-15 \\
H 1-15\end{array}$ & $\begin{array}{l}X \\
X \\
X \\
X \\
X \\
X \\
X \\
X \\
X \\
X\end{array}$ & & & $X$ \\
\hline
\end{tabular}

